\title{
Oxidação Eletroquímica de Etanol em Temperatura Ambiente e Intermediária: Estudo Quantitativo das Vias Reacionais por Espectrometria de Massas On-line.
}

\section{Exemplar revisado}

$\mathrm{O}$ exemplar original encontra-se em acervo reservado na Biblioteca do IQSC-USP

Tese apresentada ao Instituto de Química de São Carlos da Universidade de São Paulo, para obtenção do título de Doutor em Ciências.

Área de concentração: Físico-Química

Orientador: Prof. Dr. Fabio Henrique Barros de Lima 


\section{DEDICATÓRIA}

À minha família, por acreditarem e apoiarem o meu trabalho e decisões tomadas ao longo desta jornada. Mãe, seu estímulo, confiança, apoio e dedicação foi que deram, em alguns momentos, a esperança para seguir em frente. Clóvis, sua presença significou segurança e certeza de que não estou sozinha nessa caminhada. 


\section{AGRADECIMENTOS}

Agradeço inicialmente ao suporte financeiro concedido pela FAPESP (Fundação de Amparo à Pesquisa do Estado de São Paulo) Processos 2012/17581-3 e (BEPE) 2014/02032-0 e Capes (Coordenação de Aperfeioamento de Pessoal de Nível Superior), os quais foram essenciais para o desenvolvimento desta pesquisa.

Eu sou agradecida ao meu orientador, Prof. Dr. Fabio H. B. Lima, por toda sua dedicação, paciência, confiança, discussões valiosas e empenho durante todo o meu doutorado. Além é claro de toda sua contribuição para o meu desenvolvimento pessoal e profissional ao longo destes seis anos (Mestrado/Doutorado).

À Prof. Dr. Sossina M. Haile, pela oportunidade, receptividade e por todas as sugestões dadas à minha pesquisa, bem como ao seu Grupo de Pesquisa, em especial à Sara Thoi, por toda a ajuda durante meu estágio no Instituto de Tecnologia da Califórnia (California Institute of technology - Caltech), onde foi desenvolvido o estudo inicial com células de ácido sólido superprotônico.

Aos técnicos do Grupo de Eletroquímica Mauro, Jonas, Gabriel e especialmente ao Waldecir (Fio) por todo o suporte e sugestões dadas, durante à implementação do sistema para Células de Ácidos Sólidos (SAFCs), entre tantas outras ajudas, meu muito obrigado.

À Universidade de São Paulo e à todo o Grupo de Eletroquímica do Instituto de Química de São Carlos (IQSC/USP), em especial aos queridos amigos: Janete, Aniélli, Waldemir (Pino), Drielly, Nyccolas, Elenice, Thairo, Wanderson, José Luíz Bott, Edvan, Pedro, Amanda, Rashida, Luiza, Amaury, Rafael, Vanessa, Adriano, Wilson, Orlando, Márcia, Ulises, enfim, à todos os demais que estiveram presente durante toda essa jornada. 


\section{RESUMO}

$\mathrm{Na}$ primeira parte do trabalho, foram investigados materiais ativos para eletro-oxidar etanol e acetaldeído seletivos para a rota $\mathrm{C}_{2}$ (Carbono 2) e, também, ativos para eletrooxidar hidrogênio molecular, visando a aplicação em células a combustível de hidrogênio indireto. Neste tipo de célula, um processador de combustível externo desidrogena o etanol e os produtos desta reação, contendo $\mathrm{H}_{2}$, acetaldeído e, possivelmente, etanol residual, são direcionados para alimentar o ânodo. Neste sentido, o eletrocatalisador anódico pode ser ativo para a eletro-oxidação de etanol residual, bem como acetaldeído, mas este deve catalisar a reação via $\mathrm{C}_{2}$ com o objetivo de evitar a formação de espécies que envenenam a superfície catalítica $\left(\mathrm{CO}\right.$ ou $\left.\mathrm{CH}_{\mathrm{x}}\right)$, ou seja, a ligação $\mathrm{C}-\mathrm{C}$ deve permanecer intacta. Os eletrocatalisadores bimetálicos foram formados por $\mathrm{M} / \mathrm{Pt} / \mathrm{C}$ (onde $\mathrm{M}=\mathrm{W}, \mathrm{Ru}$ ou $\mathrm{Sn}$ ) e os produtos reacionais foram analisados por DEMS On-line. Os resultados mostraram que $\mathrm{Ru} / \mathrm{Pt} / \mathrm{C}$ e $\mathrm{Sn} / \mathrm{Pt} / \mathrm{C}$ apresentaram maiores taxas de reação global, no entanto, eles não foram seletivos. Por outro lado, $\mathrm{W}_{2} / \mathrm{Pt}_{3} / \mathrm{C}$ foi mais seletivo para a rota $\mathrm{C}_{2}$, dada a não formação de $\mathrm{CH}_{4}$ e $\mathrm{CO}_{2}$. Além disso, este material também foi ativo e estável para a eletro-oxidação de $\mathrm{H}_{2}$, mesmo na presença de acetaldeído, o que o torna um potencial catalisador para aplicação no ânodo de células a combustível de hidrogênio indireto. Na segunda parte do trabalho, o objetivo foi relacionado com o estudo de eletrocatalisadores seletivos para a rota $C_{1}$ (Carbono 1). A oxidação eletroquímica do etanol e de seus produtos reacionais foram investigados por DEMS online em temperatura ambiente e intermediária $\left(245^{\circ} \mathrm{C}\right)$. Para temperatura ambiente, utilizou-se solução aquosa de ácido sulfúrico $\left(\mathrm{H}_{2} \mathrm{SO}_{4}\right)$ e, para temperatura intermediária, utilizou-se ácido sólido $\left(\mathrm{CsH}_{2} \mathrm{PO}_{4}\right)$ como eletrólito. Os eletrocatalisadores investigados foram formados por $\mathrm{SnO}_{\mathrm{x}} \mathrm{RuO}_{\mathrm{x}}-\mathrm{Pt} / \mathrm{C}$ e Pt/C. Em temperatura ambiente, os resultados de polarização potenciodinâmica mostraram uma maior atividade eletrocatalítica para o material $\mathrm{SnO}_{x} \mathrm{RuO}_{\mathrm{x}}-\mathrm{Pt} / \mathrm{C}$, com eficiência de corrente para formação de $\mathrm{CO}_{2}$ de $15,6 \%$ contra $15,2 \%$ para $\mathrm{Pt} / \mathrm{C}$, sob condições estagnantes, sem controle por transporte de massa. O stripping de resíduos reacionais, após a eletro-oxidação de etanol bulk, sob condições de fluxo, mostraram o acúmulo de espécies com 1 átomo de carbono $\left(\mathrm{CO}\right.$ e $\left.\mathrm{CH}_{\mathrm{x}}\right)$ que causam o bloqueio dos sítios ativos e são oxidadas eletroquimicamente somente em mais altos potenciais ( $c a .1,0 \mathrm{~V}$ ). Por outro lado, as curvas de polarização a $245^{\circ} \mathrm{C}$ mostraram maiores valores de eficiências de correntes para formação de $\mathrm{CO}_{2}(45 \%$ para $\mathrm{Pt} / \mathrm{C} \mathrm{em}$ ambos potenciais $0,5 \mathrm{~V}$ e $0,8 \mathrm{~V}$ contra $36 \%$ e $50 \%$ para $\mathrm{SnO}_{\mathrm{x}} \mathrm{RuO}_{\mathrm{x}}-\mathrm{Pt} / \mathrm{C}$ em $0,5 \mathrm{~V}$ e 0,8 $\mathrm{V}$ respectivamente) quando comparado com os valores obtidos em temperatura ambiente, mas com atividades similares para $\mathrm{SnO}_{\mathrm{x}} \mathrm{RuO}_{\mathrm{x}}-\mathrm{Pt} / \mathrm{C}$ e $\mathrm{Pt} / \mathrm{C}$. Para ambos os eletrocatalisadores, os estudos de espectrometria de massas a $245^{\circ} \mathrm{C}$ evidenciaram que as rotas eletroquímicas ocorrem em paralelo com rotas puramente químicas, envolvendo catálise heterogênea, de decomposição do etanol, produzindo $\mathrm{H}_{2}$ e $\mathrm{CO}_{2}$ como produtos majoritários.

Palavras-chave: Eletroquímica, Eletro-oxidação, Etanol, Temperatura intermediária, Temperatura ambiente. 


\begin{abstract}
In the first part of this study were investigated active materials to electro-oxidize ethanol and acetaldehyde selective for the $\mathrm{C}_{2}$ route (Carbon 2), besides active to electro-oxidize molecular hydrogen, in order to apply into indirect hydrogen fuel cells. In this type of cell, ethanol can be dehydrogenated in the external fuel processor and the products generated in this reaction, containing $\mathrm{H}_{2}$, acetaldehyde and, possibly, unreacted ethanol are used to feed the fuel cell anode. Therefore, the anode electrocatalyst has to be active to electro-oxidize residual ethanol and acetaldehyde, however, it has to catalyze the reaction via $\mathrm{C}_{2}$ route aiming to avoid the species formation that poison the catalyst surface $\left(\mathrm{CO}\right.$ or $\mathrm{CH}_{\mathrm{x}}$ ), in the other words, the $\mathrm{C}-\mathrm{C}$ bond should remain intact. The bimetallic electrocatalysts were formed by $\mathrm{W}, \mathrm{Ru}$ and $\mathrm{Sn}$-modified $\mathrm{Pt}$ nanoparticles. The reaction products were followed by on-line differential electrochemical mass spectrometry (DEMS) experiments. The results showed that $\mathrm{Ru} / \mathrm{Pt} / \mathrm{C}$ and $\mathrm{Sn} / \mathrm{Pt} / \mathrm{C}$ presented higher overall reaction rate when compared to the other studied materials, however, they were non-selective. On the other hand, W/Pt/C with high $\mathrm{W}$ content was more selective to the $\mathrm{C}_{2}$ route, evidenced by the absence of the DEMS signals for molecules with one carbon atom such as $\mathrm{CH}_{4}$ and $\mathrm{CO}_{2}$. Additionally, this material was active and stable for $\mathrm{H}_{2}$ electro-oxidation even in the acetaldehyde presence, what turns it into a potential electrocatalyst for application in the anode of indirect hydrogen fuel cells. In the second part of this work, we investigated conditions and electrocatalysts selective to the $\mathrm{C}_{1}$ route. The ethanol electro-oxidation and its reaction products were investigated by on-line DEMS at room and intermediate temperature. At room, and intermediate temperature $\left(245^{\circ} \mathrm{C}\right)$, the electrolytes were aqueous sulfuric acid and solid-state acid $\left(\mathrm{CsH}_{2} \mathrm{PO}_{4}\right)$, respectively. The catalysts investigated were $\mathrm{SnO}_{x} \mathrm{RuO}_{\mathrm{x}}-\mathrm{Pt} / \mathrm{C}$ and $\mathrm{Pt} / \mathrm{C}$. The results of potentiodynamic polarizations at room temperature showed much higher electrocatalytic activity for the $\mathrm{SnO}_{\mathrm{x}} \mathrm{RuO}_{\mathrm{x}}-\mathrm{Pt} / \mathrm{C}$ material, with current efficiency for $\mathrm{CO}_{2}$ formation of $15.6 \%$ against $15.2 \%$ for $\mathrm{Pt} / \mathrm{C}$ under stagnant conditions. The reaction residues stripping after the ethanol electro-oxidation, under continuous flow conditions, showed the accumulation of species containing 1 carbon atom $\left(\mathrm{CO}\right.$ and $\left.\mathrm{CH}_{\mathrm{x}}\right)$, which are oxidized just at high potentials $(c a .1 .0 \mathrm{~V})$ and they cause the obstruction of the active sites. On the other hand, the polarization curves at $245^{\circ} \mathrm{C}$ showed higher values of current efficiencies ( $45 \%$ for $\mathrm{Pt} / \mathrm{C}$ for both potentials $0.5 \mathrm{~V}$ and $0.8 \mathrm{~V}$ against $36 \%$ and $50 \%$ to $\mathrm{SnO}_{\mathrm{x}} \mathrm{RuO}_{\mathrm{x}}$ $\mathrm{Pt} / \mathrm{C}$ at $0.5 \mathrm{~V}$ and $0.8 \mathrm{~V}$ respectively) for the $\mathrm{CO}_{2}$ formation than at ambient condition, however, with similar activities for $\mathrm{SnO}_{\mathrm{x}} \mathrm{RuO}_{\mathrm{x}}-\mathrm{Pt} / \mathrm{C}$ and $\mathrm{Pt} / \mathrm{C}$. For both electrocatalysts, in parallel with the electrochemical pathways, heterogeneous chemical catalysis of ethanol decomposition also takes place, producing $\mathrm{H}_{2}$ and $\mathrm{CO}_{2}$, as major products.
\end{abstract}

Keywords: Electrochemistry, Electro-oxidation, Ethanol, Intermediate temperature, Room temperature. 


\section{LISTA DE FIGURAS}

Figura 1 - Esquema das vias paralelas seguida pela reação de eletro-oxidação de etanol sobre platina em temperatura ambiente. 16

Figura 2 - Representação esquemática do sistema experimental: (a) célula eletroquímica com eletrólito estagnante e eletrodo na interface; (b) equipamento de DEMS para os experimentos eletroquímicos on-line. (1) unidade eletrônica de controle conectada com um computador; (2) câmara com analisador quadrupolar; (3) pré-câmara de vácuo; (4-5) bombas turbomoleculares; (6) entrada para a célula eletroquímica.

Figura 3 - Imagens de TEM e histogramas de distribuição do tamanho das partículas para as diferentes nanopartículas suportadas sobre carbono: (a) Sn/Pt/C (1:3); (b) $\mathrm{Ru} / / \mathrm{Pt} / \mathrm{C}$ (1:3); (c) W/Pt/C (1:3); (d) W/Pt/C (2:3) antes do tratamento térmico (TT) e (e) W/Pt/C (2:3) depois do tratamento térmico. 26

Figura 4 - Padrões de difração de raios $\mathrm{X}$ para os materiais sintetizados: $\mathrm{Sn} / \mathrm{Pt} / \mathrm{C}, \mathrm{Ru} / \mathrm{Pt} / \mathrm{C}$ e W/Pt/C todos na proporção atômica nominal (1:3), comparados com Pt/C E-TEK $20 \%$. 28

Figura 5 - (a) Stripping de CO, potencial de adsorção de $0,1 \mathrm{~V}$, eletrólito livre de $\mathrm{O}_{2}$, inserção de detalhes dos fragmentos iônicos de massas (b) $\mathrm{m} / z=44\left(\mathrm{CO}_{2}\right) \mathrm{e}$ (c) $m / z=22\left(\mathrm{CO}_{2}\right)$. Medidas realizadas em $\mathrm{H}_{2} \mathrm{SO}_{4} 0,5 \mathrm{~mol} \mathrm{~L}^{-1}$ e velocidade de varredura de $0,01 \mathrm{Vs}^{-1}$ 31

Figura 6 - (a) Perfis voltamétricos para a eletro-oxidação de etanol $0,1 \mathrm{~mol} \mathrm{~L}^{-1}$ sobre os bimetálicos investigados comparado com Pt/C E-TEK $20 \%$ a $25^{\circ} \mathrm{C}$. Velocidade de varredura de $0,01 \mathrm{~V} \mathrm{~s}^{-1}$; (b) fragmento iônico de massa $\mathrm{m} / \mathrm{z}=$ $22\left(\mathrm{CO}_{2}\right)$, inserção de detalhes (c) $\mathrm{m} / \mathrm{z}=29$ e (d) $\mathrm{m} / \mathrm{z}=44$, obtidos no experimento de DEMS on-line. $\mathrm{H}_{2} \mathrm{SO}_{4} 0,5 \mathrm{~mol} \mathrm{~L}^{-1}$

Figura 7 - (a) Curvas cronoamperométricas obtidas em experimentos de DEMS on-line para a reação de eletro-oxidação de etanol $0,1 \mathrm{~mol} \mathrm{~L}^{-1}$, seguindo os fragmentos iônicos de massa (b) $m / z=29$ e (c) $m / z=44$. $\mathrm{H}_{2} \mathrm{SO}_{4} 0,5 \mathrm{~mol} \mathrm{~L} \mathrm{~L}^{-1}$. 
Figura 8 - (a) Perfis voltamétricos para a eletro-oxidação de $0,1 \mathrm{~mol} \mathrm{~L}^{-1}$ de etanol sobre $\mathrm{Sn} / \mathrm{Pt} / \mathrm{C}(1: 3)$ e $\mathrm{Sn} / \mathrm{Pt} / \mathrm{C}(2: 3)$ a $25^{\circ} \mathrm{C}$ em solução de $\mathrm{H}_{2} \mathrm{SO}_{4} 0,5 \mathrm{~mol} \mathrm{~L}^{-1}$ e velocidade de varredura de $0,01 \mathrm{~V} \mathrm{~s}^{-1}$; fragmento iônico de massa (b) $\mathrm{m} / \mathrm{z}=$ $22\left(\mathrm{CO}_{2}\right)$, inserção de detalhes de fragmentos iônicos de massa (c) $m / z=29$ (acetaldeído) e (d) $\mathrm{m} / \mathrm{z}=44\left(\mathrm{CO}_{2}+\right.$ acetaldeído). 38

Figura 9 - (a) Perfis voltamétricos para a eletro-oxidação de $0,1 \mathrm{~mol} \mathrm{~L}^{-1}$ de etanol sobre W/Pt/C (1:3) e W/Pt/C (2:3) a $25^{\circ} \mathrm{C}$ em solução de $\mathrm{H}_{2} \mathrm{SO}_{4} 0,5 \mathrm{~mol} \mathrm{~L}^{-1} \mathrm{e}$ velocidade de varredura de $0,01 \mathrm{~V} \mathrm{~s}^{-1}$; fragmentos iônicos de massa (b) $\mathrm{m} / \mathrm{z}=$ $22\left(\mathrm{CO}_{2}\right)$, inserção de detalhes dos fragmentos iônicos de massa (c) $m / z=29$ (acetaldeído) e (d) $\mathrm{m} / \mathrm{z}=44\left(\mathrm{CO}_{2}+\right.$ acetaldeído $)$

Figura 10 - (a) Perfis voltamétricos e sinais de correntes iônicas para (b) $\mathrm{m} / z=44\left(\mathrm{CO}_{2}\right.$ + acetaldeído) e (c) $\mathrm{m} / z=22\left(\mathrm{CO}_{2}\right)$ obtidos durante medidas de DEMS para a eletro-oxidação de etanol e acetaldeído catalisada por W/Pt/C (2:3) e Pt/C

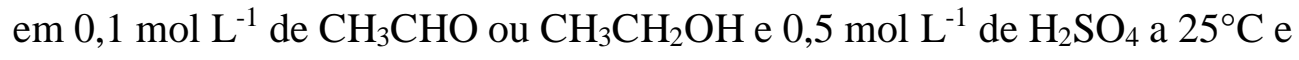
velocidade de varredura de $0,01 \mathrm{~V} \mathrm{~s}^{-1}$.

Figura 11 - (a) Perfis voltamétricos para a eletro-oxidação de $\mathrm{H}_{2}$ na ausência e na presença de $0,1 \mathrm{~mol} \mathrm{~L}^{-1}$ de acetaldeído. Velocidade de rotação do eletrodo de $1600 \mathrm{rpm}$ e velocidade de varredura de $0,01 \mathrm{~V} \mathrm{~s}^{-1}$, inserção de detalhe (b) curvas de cronoamperometria, permanecendo por $1800 \mathrm{~s}$ no potencial de $0,1 \mathrm{~V}$. 44

Figura 12 - Esquematização do sistema experimental: (a) célula eletroquímica com eletrólito estagnante; (b) célula eletroquímica de fluxo (Dual Thin Layer Flow Cell); (c) ponta porosa de Teflon (Inlet tip) para detecção dos produtos a $245^{\circ} \mathrm{C}$; (d) equipamento de DEMS para os experimentos eletroquímicos online. (1) unidade eletrônica de controle conectada com um computador; (2) câmara com analisador quadrupolar; (3) pré-câmara de vácuo; (4-5) bombas turbomoleculares; (6) entrada para a célula eletroquímica. 54

Figura 13 - Esquema do sistema usado para o estudo da reação de eletro-oxidação de etanol em célula eletroquímica sob condições de fluxo contínuo em temperatura ambiente, com acoplamento no espectrômetro de massas....... 54

Figura 14 - Esquema do sistema usado para o estudo da reação de eletro-oxidação de etanol sob condições de fluxo contínuo em célula eletroquímica com eletrólito de ácido sólido, com acoplamento no espectrômetro de massas usando um sensor de ponta (inlet tip). 
Figura 15 - Representação do procedimento usado para o cálculo das eficiências de eletro-conversão de etanol a $\mathrm{CO}_{2}$ (rota eletroquímica). 58

Figura 16 - (a) Histograma de distribuição de partículas; (b) Imagem de TEM e (c) Padrões de difração de Raios $\mathrm{X}$ obtidos para o eletrocatalisador $\mathrm{SnO}_{\mathrm{x}} \mathrm{RuO}_{\mathrm{x}^{-}}$ $\mathrm{Pt} / \mathrm{C}$ como preparado. 60

Figura 17 - (a) Perfis voltamétricos e correntes iônicas para (b) $\mathrm{m} / z=22\left(\mathrm{CO}_{2}, \mathrm{CO}_{2}{ }^{2+}\right)$ e (c) $m / z=44\left(\mathrm{CO}_{2}, \mathrm{CO}_{2}{ }^{+}\right)$obtidas durante experimentos de DEMS (stripping de CO) sobre $\mathrm{SnO}_{x} \mathrm{RuO}_{x}-\mathrm{Pt} / \mathrm{C}$ e Pt/C E-TEK em $\mathrm{H}_{2} \mathrm{SO}_{4} 0,5$ mol L ${ }^{-1}$ a $25^{\circ} \mathrm{C}$. $\mathrm{O}$ potencial foi mantido a $0,1 \mathrm{~V}$ durante 30 min em solução saturada com $\mathrm{CO}$ depois a solução foi saturada com argônio durante 30 minutos. Velocidade de varredura de $0,01 \mathrm{~V} \mathrm{~s}^{-1}$ 62

Figura 18 - (a) Perfis voltamétricos e correntes iônicas obtidas em experimentos de DEMS durante voltametria cíclica para a eletro-oxidação de etanol catalisada por $\mathrm{SnO}_{\mathrm{x}} \mathrm{RuO}_{\mathrm{x}}-\mathrm{Pt} / \mathrm{C}$ e Pt/C E-TEK (b) $\mathrm{m} / z=22\left(\mathrm{CO}_{2}{ }^{2+}\right)$; (c) $\mathrm{m} / \mathrm{z}=29$ (acetaldeído, $\mathrm{CHO}^{+}$), e (d) $\mathrm{m} / \mathrm{z}=44\left(\mathrm{CO}_{2}, \mathrm{CO}_{2}{ }^{+}\right.$e acetaldeído, $\mathrm{CH}_{3} \mathrm{CHO}^{+}$), em $0,1 \mathrm{~mol} \mathrm{~L}^{-1}$ de etanol e $\mathrm{H}_{2} \mathrm{SO}_{4} 0,5 \mathrm{~mol} \mathrm{~L}^{-1}$ a $25^{\circ} \mathrm{C}$. Velocidade de varredura de $0,01 \mathrm{~V} \mathrm{~s}^{-1}$. 64

Figura 19 - Ilustração do mecanismo bifuncional seguido pelo eletrocatalisador $\mathrm{SnO}_{\mathrm{x}} \mathrm{RuO}_{\mathrm{x}}-\mathrm{Pt} / \mathrm{C}$ para a reação de eletro-oxidação de etanol 65

Figura 20 - (a) Curvas cronoamperométricas e correntes iônicas obtidas em experimentos de DEMS para a eletro-oxidação de etanol catalisada por $\mathrm{SnO}_{x} \mathrm{RuO}_{\mathrm{x}}-\mathrm{Pt} / \mathrm{C}$ e $\mathrm{Pt} / \mathrm{C}$ E-TEK, (b) $m / z=22\left(\mathrm{CO}_{2}{ }^{++}\right)$, (c) $m / z=29$ (acetaldeído, $\mathrm{CHO}^{+}$) e (d) $\mathrm{m} / z$ $=44\left(\mathrm{CO}_{2}, \mathrm{CO}_{2}{ }^{+}\right.$e acetaldeído, $\left.\mathrm{CH}_{3} \mathrm{CHO}^{+}\right)$em $0,1 \mathrm{~mol} \mathrm{~L}^{-1}$ etanol $+0,5 \mathrm{~mol}$ $\mathrm{L}^{-1} \mathrm{H}_{2} \mathrm{SO}_{4}$ a $25^{\circ} \mathrm{C}$. As curvas cronoamperométricas foram realizadas através de saltos de potenciais, sendo as correntes registradas a cada $10 \mathrm{~min}$. 66

Figura 21 - (a) Perfis voltamétricos e (b) correntes iônicas obtidas em experimentos de DEMS durante a eletro-oxidação de etanol catalisada por $\mathrm{SnO}_{x} \mathrm{RuO}_{\mathrm{x}}-\mathrm{Pt} / \mathrm{C} \mathrm{em}$ $0,1 \mathrm{~mol} \mathrm{~L}^{-1}$ etanol $+2 \mathrm{~mol} \mathrm{~L}^{-1} \mathrm{H}_{2} \mathrm{SO}_{4}$ a $25^{\circ} \mathrm{C}$. Velocidade de varredura de 0,01 $\mathrm{V} \mathrm{s}^{-1}$. A rampa do potencial em função do tempo é mostrada em inset em (b). 
Figura 22 - (a) Perfis voltamétricos e (b) correntes iônicas $m / z=15\left(\right.$ metano, $\mathrm{CH}_{4}^{+}$) e $\mathrm{m} / \mathrm{z}$ $=44\left(\mathrm{CO}_{2}, \mathrm{CO}_{2}{ }^{+}\right)$obtidas em experimentos de DEMS durante CVs em eletrólito (2 mol L $\mathrm{L}^{-1} \mathrm{H}_{2} \mathrm{SO}_{4}$ ) catalisada por $\mathrm{SnO}_{\mathrm{x}} \mathrm{RuO}_{\mathrm{x}}-\mathrm{Pt} / \mathrm{C}$ após eletrooxidação de etanol a $25^{\circ} \mathrm{C}$. Velocidade de varredura de $0,01 \mathrm{~V} \mathrm{~s}^{-1}$. A rampa do potencial em função do tempo é mostrada como inset.

Figura 23 - Correntes iônicas $\mathrm{m} / \mathrm{z}=15\left(\right.$ metano, $\left.\mathrm{CH}_{4}{ }^{+}\right), \mathrm{m} / \mathrm{z}=22\left(\mathrm{CO}_{2}, \mathrm{CO}_{2}{ }^{2+}\right), \mathrm{m} / \mathrm{z}=$ 29 (acetaldeído, $\left.\mathrm{CHO}^{+}\right)$e $\mathrm{m} / \mathrm{z}=44\left(\mathrm{CO}_{2}, \mathrm{CO}_{2}{ }^{+}\right)$obtidas em experimentos de DEMS durante CVs em eletrólito $\left(2 \mathrm{~mol} \mathrm{~L}^{-1} \mathrm{H}_{2} \mathrm{SO}_{4}\right)$ catalisada por $\mathrm{SnO}_{\mathrm{x}} \mathrm{RuO}_{\mathrm{x}}-\mathrm{Pt} / \mathrm{C}$ após EOR a $25^{\circ} \mathrm{C}$, velocidade de varredura de $0,01 \mathrm{~V} \mathrm{~s}^{-1} . .70$

Figura 24 - (a) Perfis voltamétricos e (b) correntes iônicas obtidas em experimentos de DEMS durante a EOR catalisada por $\mathrm{SnO}_{\mathrm{x}} \mathrm{RuO}_{\mathrm{x}}-\mathrm{Pt} / \mathrm{C}$ em $0,1 \mathrm{~mol} \mathrm{~L}^{-1}$ etanol $+2 \mathrm{~mol} \mathrm{~L}^{-1} \mathrm{H}_{2} \mathrm{SO}_{4}$ a $25^{\circ} \mathrm{C}$. Velocidade de varredura de $0,01 \mathrm{mV} \mathrm{s}^{-1}$ 70

Figura 25 - Perfis voltamétricos durante medidas de eletro-oxidação de etanol catalisada por (a) $\mathrm{SnO}_{x} \mathrm{RuO}_{\mathrm{x}}-\mathrm{Pt} / \mathrm{C}$ e $\mathrm{Pt} / \mathrm{C} 50 \%$ e (b) $\mathrm{SnO}_{\mathrm{x}} \mathrm{RuO}_{\mathrm{x}}-\mathrm{Pt} / \mathrm{C}$ e Pt black em etanol $36 \%$ (linha + símbolo) e somente em eletrólito, $\mathrm{CsH}_{2} \mathrm{PO}_{4}$ (linha) a $245^{\circ} \mathrm{C}$. Velocidade de varredura $0,01 \mathrm{~V} \mathrm{~s}^{-1}$. (Sem correção por queda ôhmica).......73

Figura 26 - Curvas cronoamperométricas (a) para a eletro-oxidação de etanol em $\mathrm{SnO}_{\mathrm{x}} \mathrm{RuO}_{\mathrm{x}}-\mathrm{Pt} / \mathrm{C}$ e $\mathrm{Pt} / \mathrm{C}$ em etanol $36 \%$ a $245^{\circ} \mathrm{C}$, com monitoramento dos sinais de massa (b) $m / z=22\left(\mathrm{CO}_{2}\right)$ e (c) $m / z=2\left(\mathrm{H}_{2}\right)$. As curvas foram realizadas através de saltos potenciostáticos entre os potenciais de circuito aberto e 0,5V e 0,8 V vs. DHE (Dynamic Hydrogen Electrode), na presença e na ausência de etanol, fluxo de alimentação $7,2 \mathrm{~mL} \mathrm{~h}^{-1}$.... .75

Figura 27 - Esquema para as principais rotas reacionais seguidas pela reação de etanol (rotas químicas e eletroquímicas) em temperatura intermediária $\left(245^{\circ} \mathrm{C}\right) \ldots . .76$ 


\section{LISTA DE TABELAS}

Tabela 1 - Composição atômica média e tamanho médio de cristalito e partícula obtido por EDS, DRX e MET para os bimetálicos investigados e Pt/C E-TEK 20\%.

Tabela 2 - Eficiência média de corrente (Aq) para a formação de $\mathrm{CO}_{2}$, durante a eletrooxidação de etanol catalisada pelos diferentes eletrocatalisadores investigados, obtida em solução $0,1 \mathrm{~mol} \mathrm{~L}^{-1}$ etanol $+0,5 \mathrm{~mol} \mathrm{~L}^{-1} \mathrm{H}_{2} \mathrm{SO}_{4}$, integrando-se um ciclo voltamétrico completo.

Tabela 3 - Composição atômica média, tamanho médio de cristalito e partícula, e parâmetro de rede obtidos por X-EDS, DRX e TEM para o trimetálico investigado comparado com Pt/C E-TEK 20\%. 61

Tabela 4 - Eficiências médias de corrente (Aq) para $\mathrm{CO}_{2}$ durante a eletro-oxidação de etanol eletrocatalisada por $\mathrm{SnO}_{x} \mathrm{RuO}_{\mathrm{x}}-\mathrm{Pt} / \mathrm{C}$ e Pt/C E-TEK $20 \%$, obtidas em $0,1 \mathrm{~mol} \mathrm{~L}^{-1}$ etanol $+0,5 \mathrm{~mol} \mathrm{~L}^{-1} \mathrm{H}_{2} \mathrm{SO}_{4}$ em temperatura ambiente, integrandose um ciclo voltamétrico completo.

Tabela 5 - Eficiências médias de corrente (Aq) para $\mathrm{CO}_{2}$, durante a eletro-oxidação de etanol catalisada por $\mathrm{SnO}_{\mathrm{x}} \mathrm{RuO}_{\mathrm{x}}-\mathrm{Pt} / \mathrm{C}$ e Pt/C 50\% Alfa Aesar obtidas em 36\% de etanol a $245^{\circ} \mathrm{C}$. 


\section{SUMÁRIO}

PARTE 1: Identificação de Eletrocatalisadores para a Eletro-oxidação de Etanol e Acetaldeído: Investigação da Atividade e Seletividade para a Rota $C_{2}$ e Atividade para a Eletro-oxidação de Hidrogênio para Células a Combustível de Hidrogênio

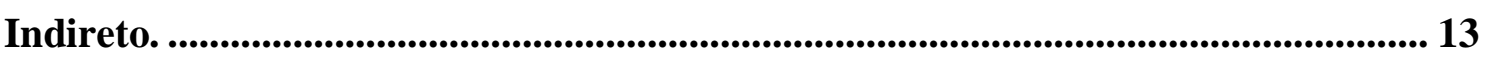

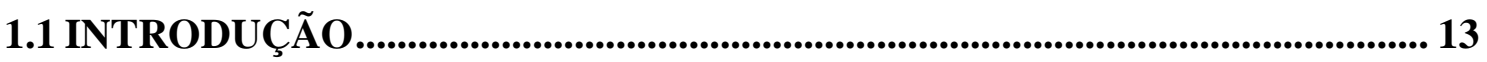

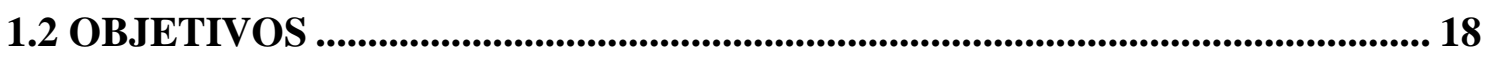

1.3 PROCEDIMENTO EXPERIMENTAL ............................................................ 19

1.3.1 Síntese e Caracterização das Nanopartículas..................................................... 19

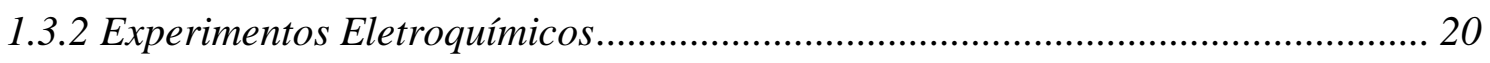

1.3.3 Espectrometria de Massas Eletroquímica Diferencial (DEMS) on-line ............... 21

1.4 RESULTADOS E DISCUSSÃO.................................................................... 25

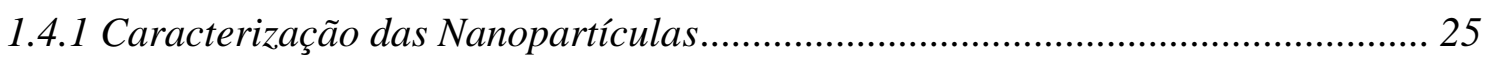

1.4.2 Experimentos de DEMS on-line para a Eletro-oxidação de Etanol, Acetaldeído e

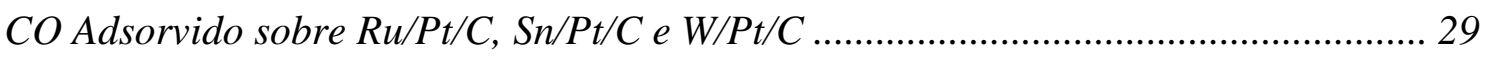

1.4.3 Experimentos para a Eletro-oxidação de Hidrogênio sobre W/Pt/C.................... 42

PARTE 2: Identificação de Eletrocatalisadores para a Eletro-oxidação de Etanol Seletivos para a Rota $C_{1}$ em Temperatura Ambiente e Intermediária: Investigação

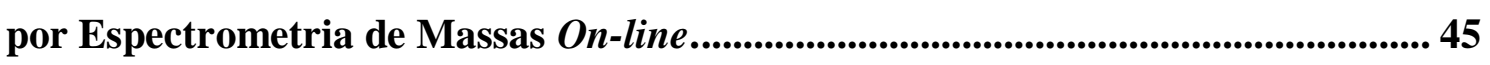

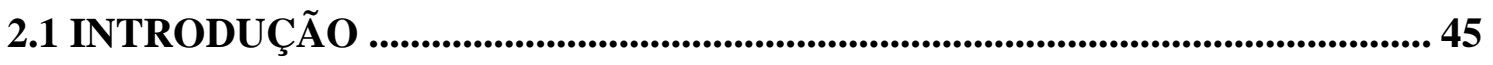

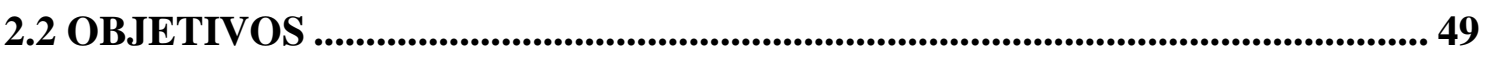

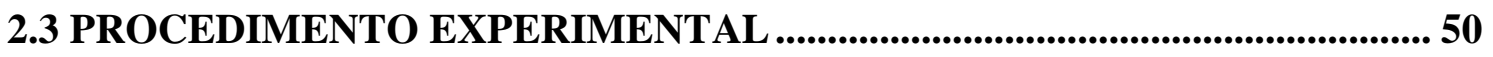

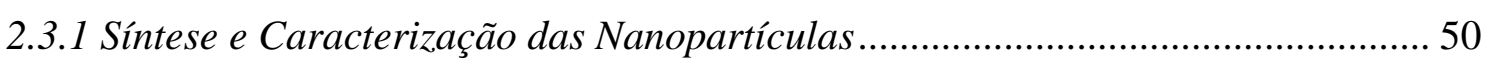

2.3.2 Preparação do Eletrólito e da Meia Célula de Ácido Sólido................................. 51 
2.3.3 Experimentos Eletroquímicos em Célula com Eletrólito Estagnante e de Fluxo em

Temperatura Ambiente. 52

2.3.4 Experimentos Eletroquímicos em Eletrólito de Ácido Sólido a $245^{\circ} \mathrm{C}$ 55

2.3.5 Determinação dos Produtos da Eletro-oxidação de Etanol por Espectrometria de Massas on-line

2.4 RESULTADOS E DISCUSSÃO. 59

2.4.1 Caracterização das Nanopartículas. 59

2.4.2 Experimentos de DEMS para a Eletro-oxidação de Etanol em Célula com Eletrólito Estagnante.

2.4.3 Experimentos de DEMS para a Eletro-oxidação de Etanol em Célula com Eletrólito em Fluxo. 66

2.4.4 Experimentos de DEMS para a Eletro-oxidação de Etanol em Temperatura Intermediária Usando Ácido Sólido como Eletrólito. 71

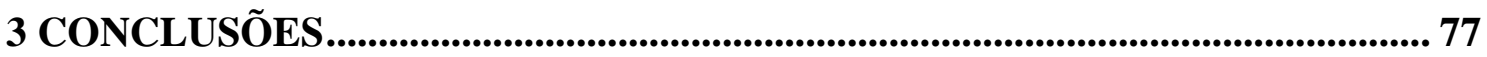

REFERÊNCIAS.. 
PARTE 1: Identificação de Eletrocatalisadores para a Eletro-oxidação de Etanol e Acetaldeído: Investigação da Atividade e Seletividade para a Rota $C_{2}$ e Atividade para a Eletro-oxidação de Hidrogênio para Células a Combustível de Hidrogênio Indireto.

Adaptado de A. C. QUEIROZ; W. O. SILVA; I. A. RODRIGUES; F. H. B. LIMA, Identification of bimetallic electrocatalysts for ethanol and acetaldehyde oxidation: Probing $\mathrm{C}_{2}$-pathway and activity for hydrogen oxidation for indirect hydrogen fuel cells. Applied Catalysis B: Environmental, v. 160-161, p. 423-435, 2014.

\subsection{INTRODUÇÃO}

A pesquisa relacionada com fontes de energia renováveis é motivada principalmente pelo consumo crescente de combustíveis fósseis, além da degradação ambiental causada pela poluição gerada por gases liberados em máquinas térmicas. Assim, diversos pesquisadores têm trabalhado no desenvolvimento de células a combustível. Dentre os combustíveis considerados promissores, o etanol tem ganhado destaque, uma vez que, além de ser um combustível renovável, sua eletro-oxidação total libera um grande número de elétrons por molécula. Além de vários outros aspectos positivos relacionados a este combustível, tais como baixa toxicidade e produção em larga escala. No entanto, a eletro-oxidação total do etanol em temperatura ambiente têm se mostrado um processo bastante complexo e a reação segue diferentes vias reacionais paralelas com menor número de elétrons, ao invés de seguir a rota de formação de $\mathrm{CO}_{2}$. Neste sentido, o uso de etanol em células a combustível de hidrogênio indireto se torna bastante atrativo.

O hidrogênio molecular é considerado uma fonte de energia limpa, além de poder ser produzido a partir de outras fontes de energia, como do etanol por exemplo. $\mathrm{H}_{2}$ pode ser armazenado na forma líquida ou gasosa [1-3] ou armazenado por hidrogenação 
de compostos orgânicos ou inorgânicos [4,5]. O ciclo de hidrogenação/desidrogenação pode ser realizado por catálise química heterogênea (desidrogenação térmica) ou por oxidação/redução eletroquímica. Neste último caso, a hidrogenação é alcançada por redução eletroquímica de uma molécula oxidada, e a desidrogenação (produção de $\mathrm{H}_{2}$ ) pode ser realizada por reforma eletroquímica [6,7]. No caso das moléculas serem orgânicas, como discutido em trabalhos prévios [8-10], estes materiais podem ser chamados de "hidretos orgânicos", porque eles podem "absorver" e "dessorver" hidrogênio como hidretos metálicos por reações catalíticas.

O hidrogênio presente nas moléculas que sofreram hidrogenação ou mesmo em moléculas com alto conteúdo de hidrogênio pode ser eficientemente utilizado para a conversão de energia em células a combustível, onde a energia química de um combustível é convertida em energia elétrica. Estes dispositivos são importantes principalmente devido à alta eficiência termodinâmica teórica (97\%) [11]. Além disso, células a combustível tem uma ampla variedade de aplicação, que vão desde o uso em dispositivos eletrônicos portáteis ao uso como energia elétrica de segurança para edifícios industriais ou comerciais. Basicamente, há duas principais rotas para usar a molécula hidrogenada ou "reduzida": (a) célula a combustível indireta: neste caso, a molécula hidrogenada é submetida a uma desidrogenação térmica catalítica e o $\mathrm{H}_{2}$ liberado alimenta uma célula a combustível de hidrogênio convencional, por exemplo, do tipo PEM (Proton Exchange Membrane) [12-15]; (b) célula a combustível direta ou célula a combustível de "hidrogênio virtual” [16-18]: neste caso, ao invés de liberar gás hidrogênio, este passo pode ser substituído por uma etapa de oxidação eletroquímica, que libera prótons e elétrons [8]. Para o último caso, as células a combustível podem operar em dois regimes: (i) como uma célula a combustível regenerativa ou recarregável, que usa um ciclo de hidrogenação/desidrogenação reversível de uma molécula orgânica particular [19], e (ii) 
como um dispositivo eletroquímico não recarregável ou não regenerativo, em que o combustível é eletroquimicamente e irreversivelmente oxidado a uma molécula, tal como $\mathrm{CO}_{2}$

A comparação entre os diversos tipos de combustíveis estudados para o item (ii) mostra que o etanol vem ganhando destaque, principalmente devido ao seu alto conteúdo de hidrogênio ou alta densidade de energia, baixa toxicidade e possibilidade de ser produzido em grande quantidade a partir da fermentação da biomassa, o que oferece uma viabilidade econômica interessante. Etanol pode ser usado em células a combustível indiretas ou diretas (Direct Ethanol Fuel Cell - DEFC) [18]. Assim, no primeiro caso, o eletrocatalisador do ânodo tem que ser ativo para a eletro-oxidação de $\mathrm{H}_{2}$ e tolerante (inativo) à presença dos subprodutos de desidrogenação, tais como acetaldeído e, eventualmente, etanol não reagido. Para o último caso, os eletrocatalisadores devem ser eficientes para a eletro-oxidação de etanol a $\mathrm{CO}_{2}$.

Conforme mencionado anteriormente a eletro-oxidação total do etanol a $\mathrm{CO}_{2}$ libera 12 elétrons por molécula, como mostrado no esquema da Figura 1. Há duas principais rotas para a reação de eletro-oxidação de etanol, como proposto anteriormente [20-22]: as vias $\mathrm{C}_{1}$ e $\mathrm{C}_{2}$ (ver Figura 1). $\mathrm{Na}$ via $\mathrm{C}_{1}$, a ligação $\mathrm{C}-\mathrm{C}$ é quebrada no etanol ou no acetaldeído, produzindo espécies $\mathrm{CO}_{\mathrm{ad}}$ e $\mathrm{CH}_{\mathrm{x} \text {,ad }}$ que, eventualmente, se oxidam a $\mathrm{CO}_{2}$ [20,23]. Na via $\mathrm{C}_{2}$, a ligação C-C do etanol permanece intacta após oxidação, e este é convertido a acetaldeído e, eventualmente, a ácido acético. Platina é considerada o melhor eletrocatalisador monometálico para a reação de eletro-oxidação de etanol, mas ainda assim apresenta uma baixa eficiência faradaica para a formação de $\mathrm{CO}_{2}$ [24,25]. Vários trabalhos usando eletrocatalisadores bi e trimetálicos têm mostrado um aumento da taxa reacional global, mas até o momento, as eficiências de correntes faradaicas obtidas para 
a formação de $\mathrm{CO}_{2}$ (ou caminho $\mathrm{C}_{1}$ ) são insuficientes (menores do que 5\%) para o desenvolvimento de sistemas práticos [20,21,23,25-38].

Figura 1 - Esquema das vias paralelas seguida pela reação de eletro-oxidação de etanol sobre platina em temperatura ambiente.

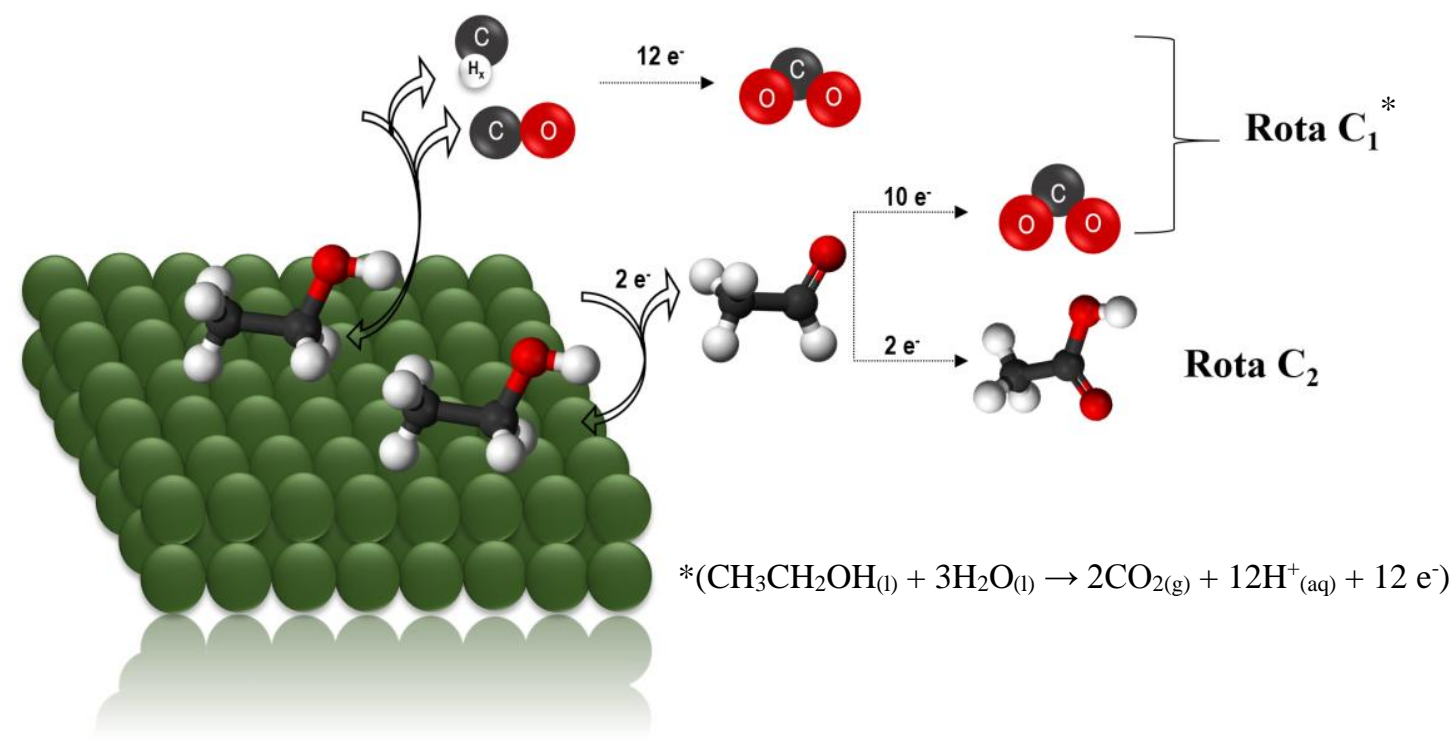

Fonte: Autoria própria

O etanol pode ser desidrogenado em um processador de combustíveis e os produtos desta reação, contendo $\mathrm{H}_{2}$, acetaldeído e possivelmente etanol residual podem ser usados para alimentar o ânodo de uma célula a combustível. Logo, o eletrocatalisador do ânodo precisa ser ativo para a eletro-oxidação de hidrogênio e, adicionalmente, deve ser ativo para a eletro-oxidação de etanol (que não sofreu oxidação na etapa de desidrogenação) ou acetaldeído. Isto contribuirá para aumentar a corrente faradaica global (na rota $\mathrm{C}_{2}$, etanol para acetaldeído ou ácido acético, e acetaldeído para ácido acético). No entanto, se ativo, o catalisador deve conduzir a eletro-oxidação de etanol e acetaldeído via rota $\mathrm{C}_{2}$ (ligação $\mathrm{C}-\mathrm{C}$ intacta), a fim de evitar a formação de espécies envenenadoras adsorvidas, contendo um átomo de carbono, tais como $\mathrm{CO}_{\text {e }} \mathrm{CH}_{\mathrm{x}}$, que não são oxidadas em baixos potenciais. Esta célula a combustível poderia ser usada, por 
exemplo, como uma unidade de energia auxiliar de um motor de combustão interna de um carro, abastecido com etanol.

Ainda neste contexto, uma célula a combustível poderia ser alimentada com uma parte do etanol, gerando eletricidade, e os subprodutos da desidrogenação (ou etanol residual), não utilizados poderiam ser bombeados de volta ao tanque de etanol para adicional combustão. Isto poderia ser, portanto, uma inovação significativa para a aplicação prática das células a combustível [39]. Uma tentativa para a busca de eletrocatalisadores que são seletivos para oxidar etanol ou acetaldeído via caminho $\mathrm{C}_{2} \mathrm{e}$, além disso, ativos para a eletro-oxidação de hidrogênio molecular, é algo novo na literatura. Logo, investigações nesta direção são muito importantes para o desenvolvimento de células a combustível de hidrogênio indireto.

De acordo com Song e co-autores [40] o catalisador $\mathrm{PtSn} / \mathrm{C}$ exibe maior atividade eletrocatalítica para a eletro-oxidação de etanol do que PtRu/C. No entanto, os produtos majoritários desta oxidação possuem a ligação C-C intacta. Tal conclusão é também dividida por outros autores [41-44]. Em ligas com estanho foi observado que estas reduzem a produção de $\mathrm{CH}_{3} \mathrm{CHO}$ e $\mathrm{CO}_{2}$, mas aumentam a seletividade para $\mathrm{CH}_{3} \mathrm{COOH}$ quando comparado com Pt/C. Desta forma, os catalisadores selecionados para este estudo foram formados por platina em combinação com metais oxofílicos, tais como Sn, Ru e W. 


\subsection{OBJETIVOS}

Considerando-se o cenário exposto, o objetivo geral da primeira etapa deste trabalho foi relacionado com a investigação de materiais em potencial que sejam ativos para a eletro-oxidação de etanol e acetaldeído via $\mathrm{C}_{2}$, e ativos para a eletro-oxidação de hidrogênio molecular.

Deste modo os objetivos específicos foram definidos como:

- Síntese e estudo da atividade eletrocatalítica de nanopartículas formadas por $\mathrm{Ru} / \mathrm{Pt} / \mathrm{C}$, W/Pt/C e Sn/Pt/C em diferentes composições atômicas;

- Correlação entre a composição do eletrocatalisador e a distribuição dos produtos reacionais por Espectrometria de Massas Eletroquímica Diferencial (DEMS on-line - Differential Electrochemical Mass Spectrometry On-line);

- Investigação da reação de eletro-oxidação de hidrogênio na ausência e na presença de acetaldeído, catalisada pelo material mais seletivo para a rota $C_{2}$.

A relevância deste trabalho de pesquisa pode ser descrita pela importância do etanol como combustível para a conversão de sua energia química em energia elétrica, em células a combustível, bem como a compreensão dos fatos que governam a atividade eletrocatalítica de diferentes eletrocatalisadores e a quantificação das vias reacionais ou da eficiência de eletro-conversão para o avanço na compreensão da catálise da reação. 


\subsection{PROCEDIMENTO EXPERIMENTAL}

\subsubsection{Síntese e Caracterização das Nanopartículas}

Os eletrocatalisadores foram formados por nanopartículas de Pt modificadas com $\mathrm{Ru}, \mathrm{Sn}$ e W, representados por $\mathrm{Ru} / \mathrm{Pt} / \mathrm{C}, \mathrm{Sn} / \mathrm{Pt} / \mathrm{C}$ e W/Pt/C, respectivamente (liga ou solução sólida - dependendo da combinação entre os metais). Os eletrocatalisadores foram sintetizados com razões atômicas nominais (Metal: Pt) de 1:3 e 2:3, adaptando um método previamente publicado [29]. Para as sínteses, quantidades apropriadas de $\mathrm{RuCl}_{2}, \mathrm{SnCl}_{2}$ ou $\mathrm{WCl}_{6}$ (sendo $\mathrm{WCl}_{6}$ inicialmente solubilizado em $25 \mathrm{~mL}$ de uma solução de $\mathrm{NaOH} 0,1 \mathrm{~mol} \mathrm{~L}^{-1}$ ) e $\mathrm{H}_{2} \mathrm{PtCl}_{2} \cdot 6 \mathrm{H}_{2} \mathrm{O}$ (Sigma-Aldrich) foram solubilizadas em água ultra pura, seguida pela adição de carbono de alta área (Vulcan XC-72, Cabot, $250 \mathrm{~m}^{2} \mathrm{~g}^{-1}$ ). A suspensão resultante foi agitada e sonicada por 10 minutos em ar em temperatura ambiente. Após isto, a solução foi agitada e aquecida a $80^{\circ} \mathrm{C}$ até completa evaporação do solvente em um béquer. As amostras foram resfriadas em ar, e os pós, impregnados foram submetidos a tratamento térmico, conduzido em um forno tubular (MAITEC) em atmosfera de argônio a $300^{\circ} \mathrm{C}$, por 1 hora, seguido pelo tratamento em atmosfera de $\mathrm{H}_{2}$ a $300{ }^{\circ} \mathrm{C}$ por 3 horas.

As composições atômicas dos eletrocatalisadores resultantes foram estimadas por análises de espectroscopia de energia dispersiva de raios-X (X-EDS), usando um ZeissLeica/LEO modelo 440 (LEO, UK) acoplado ao microanalisador Link Analytical (QX2000). A distribuição das nanopartículas metálicas sobre o suporte de carbono e os tamanhos de partículas foram investigados por medidas de Microscopia Eletrônica de Transmissão (TEM), usando um microscópio Jeol 2010, suportando um filamento de 
$\mathrm{LaB}_{6}$ e operado a $200 \mathrm{kV}$. As amostras foram preparadas pelo tratamento de ultrassom dos pós dos eletrocatalisadores em álcool isopropílico. Uma gota da suspensão resultante foi colocada sobre um filme fino de carbono depositado sobre uma grade de cobre padrão TEM e seco em ar. As imagens foram adquiridas observando diferentes áreas das amostras, a fim de avaliar suas características médias. Os diâmetros das partículas foram medidos nas imagens de TEM usando o software ImageJ. No mínimo, 500 nanopartículas de cada amostra foram medidas para construir os histogramas de distribuição de tamanho. Características estruturais também foram investigadas por medidas de difração de Raios $\mathrm{X}$, utilizando um difratômetro RIGAKU modelo ULTIMA IV, com radiação $\mathrm{Cu} \mathrm{K}_{\alpha}(\lambda=$ $1,54056 \AA$ ), , operado a $40 \mathrm{kV}$ e $40 \mathrm{~mA}$, e entre $20^{\circ}-100^{\circ}$, com uma velocidade de varredura de $0,3^{\circ} \mathrm{min}^{-1}$. Os tamanhos médios dos cristalitos foram estimados a partir do pico (111) do padrão de difração da Pt, utilizando a equação de Scherrer [45] e os parâmetros de rede (a) foram calculados pelo método dos mínimos quadrados [46].

\subsubsection{Experimentos Eletroquímicos}

Medidas eletroquímicas de voltametria cíclica e cronoamperometria foram realizadas usando um AUTOLAB PGSTAT 30 equipado com um módulo analógico. Todos os experimentos foram realizados em eletrólito de $\mathrm{H}_{2} \mathrm{SO}_{4} 0,5 \mathrm{~mol} \mathrm{~L}-1$, preparado com reagentes de alta pureza (Sigma-Aldrich) e água purificada em um sistema Milli-Q (Millipore), sob temperatura controlada de 25,0 $\pm 0,1^{\circ} \mathrm{C}$ usando um termostato HakeeK20. Uma folha de platina platinizada na forma de um anel serviu como contra eletrodo e um eletrodo reversível de hidrogênio (ERH), no mesmo eletrólito, foi usado como eletrodo de referência. A oxidação eletroquímica de etanol ou acetaldeído foi realizada utilizando um eletrodo poroso no equipamento de DEMS em solução de $0,5 \mathrm{~mol} \mathrm{~L}^{-1}$ 
$\mathrm{H}_{2} \mathrm{SO}_{4} / 0,1 \mathrm{~mol} \mathrm{~L}^{-1} \mathrm{C}_{2} \mathrm{H}_{5} \mathrm{OH}$ ou acetaldeído sob condições estagnantes, sem controle por transporte de massa. A oxidação eletroquímica de hidrogênio molecular ou reação de oxidação de hidrogênio foi medida usando um eletrodo de disco rotatório (Rotating Disk Electrode - RDE) em eletrólito de $\mathrm{H}_{2} \mathrm{SO}_{4} 0,5 \mathrm{~mol} \mathrm{~L} \mathrm{~L}^{-1}$ saturado com $\mathrm{H}_{2}$ a $1600 \mathrm{rpm}$. Para este caso, uma suspensão de 2,0 $\mathrm{mg} \mathrm{mL}^{-1}$ de metal/C foi preparada, dispersando o pó do catalisador em álcool isopropílico usando um ultrassom [47]. Uma alíquota de $20 \mu \mathrm{L}$ da suspensão dispersada foi pipetada sobre um disco de carbono vítreo de um eletrodo de disco rotatório $\left(5 \mathrm{~mm}\right.$ diâmetro e área $\left.0,196 \mathrm{~cm}^{2}\right)$ e seco sob vácuo.

\subsubsection{Espectrometria de Massas Eletroquímica Diferencial (DEMS) on-line}

A quantificação dos produtos reacionais da eletro-oxidação de etanol em meiacélula eletroquímica com eletrólito estagnante, sem controle por transporte de massa, foi feita com o uso da espectrometria de massas. A técnica de DEMS (Differential Electrochemical Mass Spectrometry) on-line permite o monitoramento da corrente faradaica e a natureza e quantidade das espécies químicas geradas na interface eletrodo/eletrólito [48,49]. O equipamento de DEMS é formado por uma conexão de uma célula eletroquímica a um espectrômetro de massas, usando um eletrodo poroso hidrofóbico como interface entre o alto vácuo no espectrômetro de massa e a pressão atmosférica na célula eletroquímica. Assim, é possível a coleta dos produtos voláteis das reações eletroquímicas diretamente no sistema de entrada de um espectrômetro de massas usual. O uso de bombas turbomoleculares conduz a um rápido tempo de resposta $(\sim 0,2$ s), o que permite a detecção on-line dos produtos formados, em função do potencial do eletrodo ou do tempo. 
O sistema experimental encontra-se ilustrado na Figura 2, onde: (a) célula eletroquímica e (b) o equipamento de DEMS, sendo (1) unidade eletrônica de controle conectada com um computador; (2) câmara com analisador quadrupolar; (3) pré-câmara de vácuo; (4-5) bombas turbomoleculares; (6) entrada para a célula eletroquímica. A célula eletroquímica (Figura 2(a)) é acoplada na entrada do espectrômetro de massas quadrupolar (6). As substâncias na interface da membrana hidrofóbica se difundem para a pré-câmara (3). Na pré-câmara, uma baixa pressão é mantida por uma bomba turbomolecular (5). Nesta câmara, a maioria dos gases que entram no espectrômetro de massas (principalmente moléculas de água) é eliminada e uma porção mais restrita entra em uma segunda câmara (2), onde esta o analisador de massas (analisador quadrupolar).

Figura 2 - Representação esquemática do sistema experimental: (a) célula eletroquímica com eletrólito estagnante e eletrodo na interface; (b) equipamento de DEMS para os experimentos eletroquímicos on-line. (1) unidade eletrônica de controle conectada com um computador; (2) câmara com analisador quadrupolar; (3) pré-câmara de vácuo; (4-5) bombas turbomoleculares; (6) entrada para a célula eletroquímica.

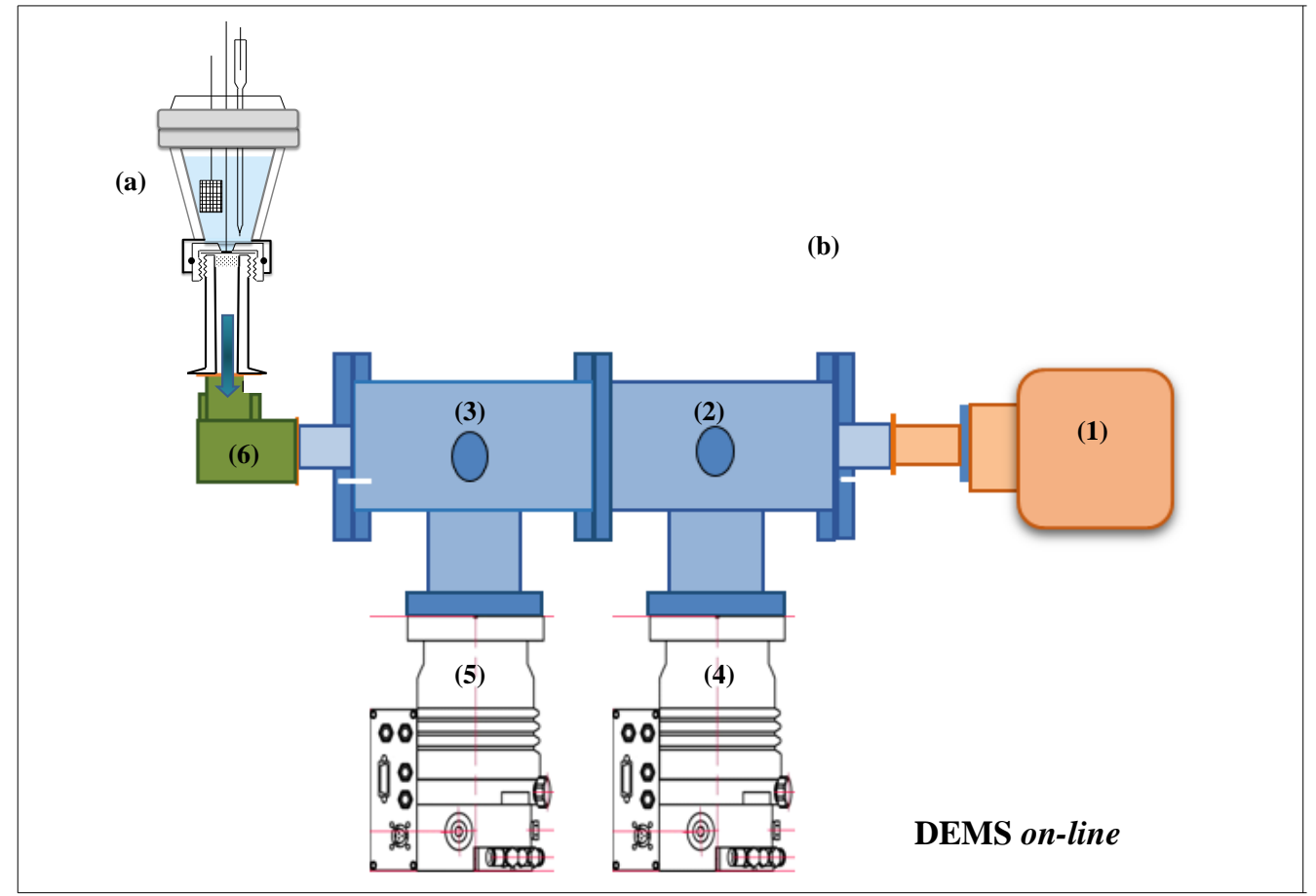


Para as medidas de DEMS, os eletrodos de trabalho foram preparados na forma de um filme fino pipetando $180 \mu \mathrm{L}$ de uma suspensão aquosa do eletrocatalisador $(2,0$ mg em 1,0 mL de álcool isopropílico $+50 \mu \mathrm{L}$ de uma solução de $\mathrm{Nafion}^{\circledR}-5$ wt.\%, Aldrich) [47] sobre uma camada de ouro (área de $1,13 \mathrm{~cm}^{2}$ e espessura de $50 \mathrm{~nm}$ ), obtida por pulverização (Sputter deposition) sobre uma membrana de Teflon (Gore-Tex®, PTFE (diâmetro de poro de $0,02 \mu \mathrm{m}$ ), que é a própria interface entre o alto vácuo do espectrômetro de massa e o eletrólito da célula, resultando em $120 \mu \mathrm{gmetal}_{\mathrm{cm}}{ }^{-2}$. Após a evaporação do álcool em temperatura ambiente, os eletrodos foram lavados com água ultrapura e inseridos na célula eletroquímica de DEMS. A célula eletroquímica foi construída seguindo os princípios previamente publicados $[48,50]$. Nos experimentos deste trabalho, as curvas de corrente versus potencial foram registradas simultaneamente com as curvas de intensidade de massa versus potencial, para os valores selecionados de sinais iônicos $\mathrm{m} / \mathrm{z}$ (massa/carga). O eletrodo foi ciclado no intervalo de potenciais de 0,1 a $1,0 \mathrm{~V}$ para os materiais bimetálicos e entre 0,1 a $1,2 \mathrm{~V}$ para $\mathrm{Pt} / \mathrm{C}$, todos com uma velocidade de varredura de $0,01 \mathrm{~V} \mathrm{~s}^{-1}$ e sob condições estagnantes.

Os produtos da eletro-oxidação de etanol foram monitorados individualmente. Dióxido de carbono e acetaldeído foram analisados pelo monitoramento dos sinais iônicos de massa $\mathrm{m} / z=22$ (sinal duplamente ionizado $\mathrm{CO}_{2}{ }^{++}$), $\mathrm{m} / \mathrm{z}=29$ (acetaldeído), e $m / z=44$ (acetaldeído $+\mathrm{CO}_{2}$ ) [51-53]. Análises quantitativas de medidas de DEMS foram realizadas de acordo com procedimentos prévios [24]. As eficiências médias de corrente para a completa eletro-oxidação de etanol a $\mathrm{CO}_{2}$ por átomo de carbono (12 elétrons por molécula de etanol) foram calculadas usando a seguinte equação:

$$
A_{q}\left(\mathrm{CO}_{2}\right)=\frac{6 Q_{i}}{K_{22}^{*} Q_{f}}
$$


$A_{i}\left(\mathrm{CO}_{2}\right)=\frac{6 I_{i}}{K_{22}^{*} I_{f}}$

Onde $Q_{f}$ e $I_{f}$ são a carga faradaica e a corrente faradaica durante a oxidação de etanol, respectivamente, e $Q_{i}$ e $I_{i}$ são a carga do fragmento de massa correspondente e a corrente de $m / z=22$. O fator 6 refere-se ao número de elétrons necessários para a formação de uma molécula de $\mathrm{CO}_{2}$ proveniente do etanol, e $\mathrm{K}_{22}{ }^{*}$ é a constante de calibração para o fragmento $m / z=22$ determinado pela oxidação de $\mathrm{CO}_{\mathrm{ad}}$ (stripping de $\mathrm{CO}$ ) ou oxidação do $\mathrm{CO}$ bulk sobre o eletrocatalisador. Para a oxidação de $\mathrm{CO}_{\mathrm{ad}}$ e $\mathrm{CO}$ bulk, respectivamente, $\mathrm{K}_{22}{ }^{*}$ foi calculado por:

$K_{22}^{*}=\frac{2 Q_{i}}{Q_{\mathrm{f}}}$

$\mathrm{Ou}$

$K_{22}^{*}=\frac{2 I_{\mathrm{i}}}{I_{\mathrm{f}}}$

Em que $Q_{\mathrm{f}}$ e $I_{\mathrm{f}}$ são a carga faradaica e a corrente faradaica durante a oxidação de $\mathrm{CO}_{\mathrm{ad}} \mathrm{e}$ oxidação de $\mathrm{CO}$ bulk, respectivamente, $Q_{\mathrm{i}}$ e $I_{\mathrm{i}}$ são a carga do fragmento de massa correspondente e a corrente de $m / z=22$. O fator 2 refere-se ao número de elétrons necessários para a formação de uma molécula de $\mathrm{CO}_{2}$ proveniente de $\mathrm{CO}_{\mathrm{ad}}$ ou $\mathrm{CO}$ bulk. Para os experimentos de stripping de $\mathrm{CO}$, a saturação de $\mathrm{CO}$ sobre a superfície eletrocatalítica foi alcançada borbulhando $\mathrm{CO}$ na solução por 10 minutos com o eletrodo polarizado em $0,1 \mathrm{~V}$, seguido por borbulhamento com $\mathrm{N}_{2}$ por 30 minutos a fim de eliminar o CO dissolvido [54]. 


\subsection{RESULTADOS E DISCUSSÃO}

\subsubsection{Caracterização das Nanopartículas}

As razões atômicas determinadas por medidas de X-EDS estão apresentadas na Tabela 1. Os resultados mostram que as razões atômicas foram próximas de 1:4 (metal: platina), ao invés do valor nominal desejado de 1:3. Para W/Pt/C, com maior quantidade de $\mathrm{W}$, no entanto, o resultado foi mais próximo ao valor nominal de 2:3. As diferenças nas razões atômicas obtidas podem ter surgido da hidratação dos sais precursores, que interferem nos valores pesados durante a síntese, assim como do método de preparação empregado (tratamento térmico em alta temperatura, $300{ }^{\circ} \mathrm{C}$, sob uma atmosfera de hidrogênio).

As microscopias eletrônicas de transmissão e os histogramas de distribuição dos diâmetros das partículas, obtidos para os diferentes materiais investigados estão apresentados na Figura 3. As imagens revelam distribuição uniforme das nanopartículas metálicas sobre o suporte de carbono, mas com distribuição heterogênea em tamanho. De acordo com os histogramas obtidos, os três diferentes materiais com razões atômicas 1:3 apresentaram tamanho médio de partícula no intervalo de 2 a $10 \mathrm{~nm}$, e alguns aglomerados largos de partículas no intervalo de $12-20 \mathrm{~nm}$. O efeito do tratamento térmico foi também investigado, e os resultados de TEM para W/Pt/C (2:3) antes e depois do tratamento térmico sob atmosfera de hidrogênio a $300^{\circ} \mathrm{C}$ estão mostrados nas Figuras 1(d) e 1(e) respectivamente. Como pode ser observado, há somente uma pequena mudança no histograma de distribuição das partículas (de 4,5 a 5,0 nm), indicando que o tratamento térmico empregado nas sínteses não teve um efeito severo sobre o aumento do tamanho das partículas dos eletrocatalisadores. 
Figura 3 - Imagens de TEM e histogramas de distribuição do tamanho das partículas para as diferentes nanopartículas suportadas sobre carbono: (a) Sn/Pt/C (1:3); (b) $\mathrm{Ru} / / \mathrm{Pt} / \mathrm{C}$ (1:3); (c) W/Pt/C (1:3); (d) W/Pt/C (2:3) antes do tratamento térmico (TT) e (e) W/Pt/C (2:3) depois do tratamento térmico.
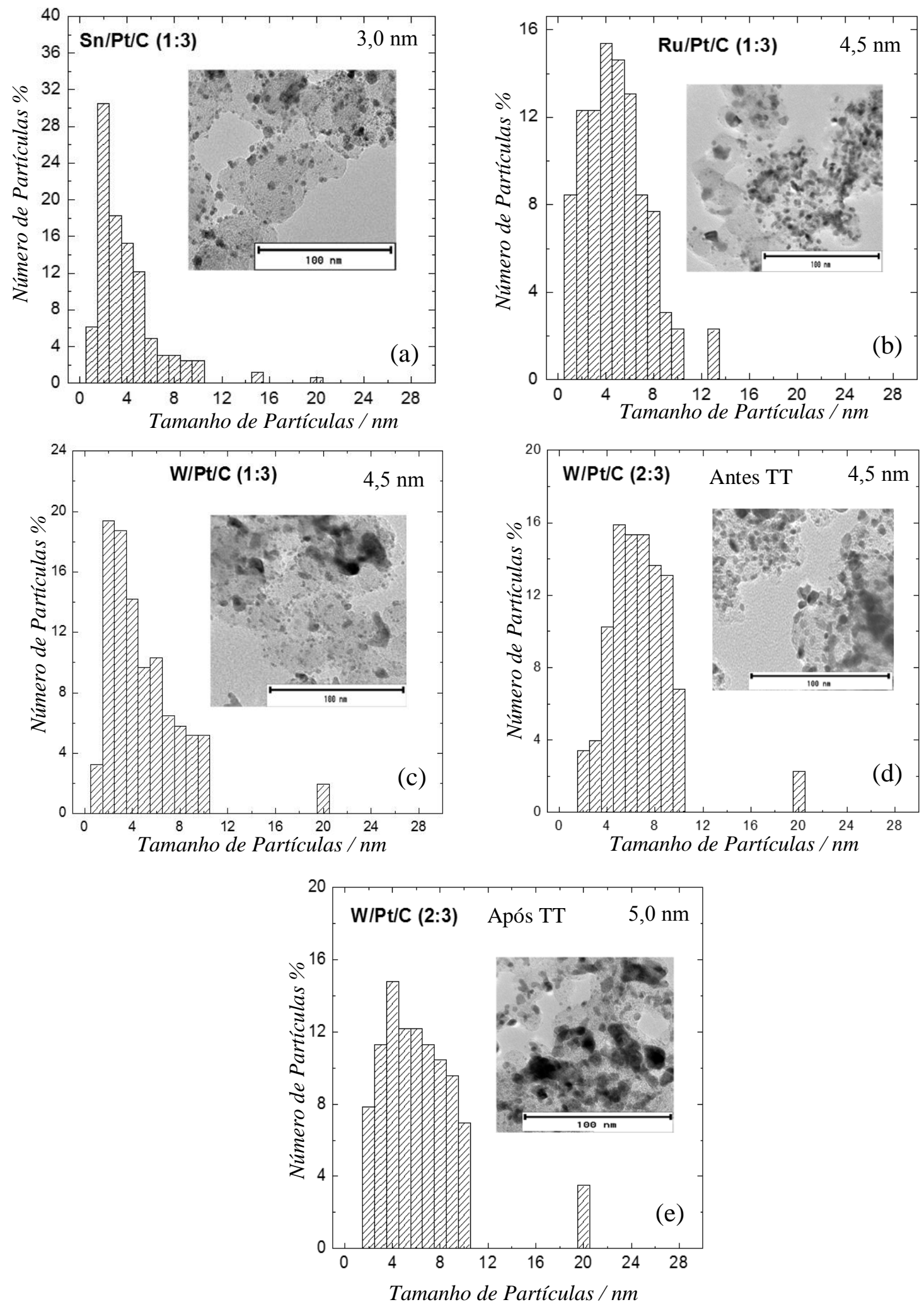

Fonte: Adaptado de A. C. QUEIROZ, et al., Applied Catalysis B: Environmental, v. 160-161, p. 423-435, 2014. 
A Figura 4 apresenta os padrões de difração de Raios X obtidos para os planos (111) e (311) relativos a platina para os materiais sintetizados $\mathrm{Ru} / \mathrm{Pt} / \mathrm{C}, \mathrm{Sn} / \mathrm{Pt} / \mathrm{C}$ e W/Pt/C. O resultado para nanopartículas de Pt/C (E-TEK 20\%) foi incluído para comparação. Estes padrões estão relacionados com a estrutura cristalina cúbica de face centrada (fcc) da Pt. Como pode ser observado, os picos de difração são somente levemente deslocados para maiores ângulos com respeito aqueles do eletrocatalisador de $\mathrm{Pt} / \mathrm{C}$. Isto indica baixo grau de formação de liga. De fato, os parâmetros de rede calculados, apresentados na Tabela 1, mostram pouca mudança na estrutura, evidenciando baixa inserção de átomos de $\mathrm{Ru}$, Sn ou W na estrutura da Pt. No caso do material Sn/Pt/C, são claramente observados reflexões adicionais, como marcado na figura, que são relacionadas à fase definida $\mathrm{Pt}_{3} \mathrm{Sn}$, indicando formação de liga entre $\mathrm{Pt}$ e $\mathrm{Sn}$, com um valor mais alto do parâmetro de rede $(0,3996 \mathrm{~nm})$, devido ao maior tamanho do átomo de Sn comparado ao de Pt. No entanto, esta é uma fase minoritária, como evidenciada indiretamente pela baixa intensidade dos picos de difração. Portanto, pode ser inferido que a maior parte do eletrocatalisador é formada por fases segregadas, mas com contato íntimo dos átomos metálicos, e com baixa inserção dos átomos de Ru, Sn, ou W na estrutura da Pt.

Além disso, picos de difração mais estreitos podem ser observados para os materiais bimetálicos, enquanto aqueles de Pt/C são mais largos, indicando cristalitos maiores para os materiais bimetálicos. De fato, os cálculos dos tamanhos médios de cristalitos, feitos utilizando-se a equação de Sherrer, também apresentados na Tabela 1, resultaram em cristalitos maiores para os materiais bimetálicos, quando comparado aquele para Pt/C. O maior tamanho de cristalito para os materiais bimetálicos pode ser atribuído ao método de síntese adotado (tratamento térmico), visto que este método de preparação não permite controlar satisfatoriamente o tamanho das nanopartículas e cristalitos. Além disso, são observados maiores cristalitos para os materiais com W, o que 
pode indicar mais alta suscetibilidade de crescimento durante a síntese. Vale a pena notar que os valores calculados de tamanhos de cristalitos são maiores do que os tamanhos médios de partículas obtidos por TEM. Isto é atribuída a maior contribuição de cristalitos mais largos, presente em todo material investigado, resultando em altos valores de tamanhos de cristalito, como calculado usando a equação de Scherrer.

Figura 4 - Padrões de difração de Raios $X$ para os materiais sintetizados: $\mathrm{Sn} / \mathrm{Pt} / \mathrm{C}$, $\mathrm{Ru} / \mathrm{Pt} / \mathrm{C}$ e W/Pt/C, todos na proporção atômica nominal (1:3), comparados com Pt/C E-TEK $20 \%$.

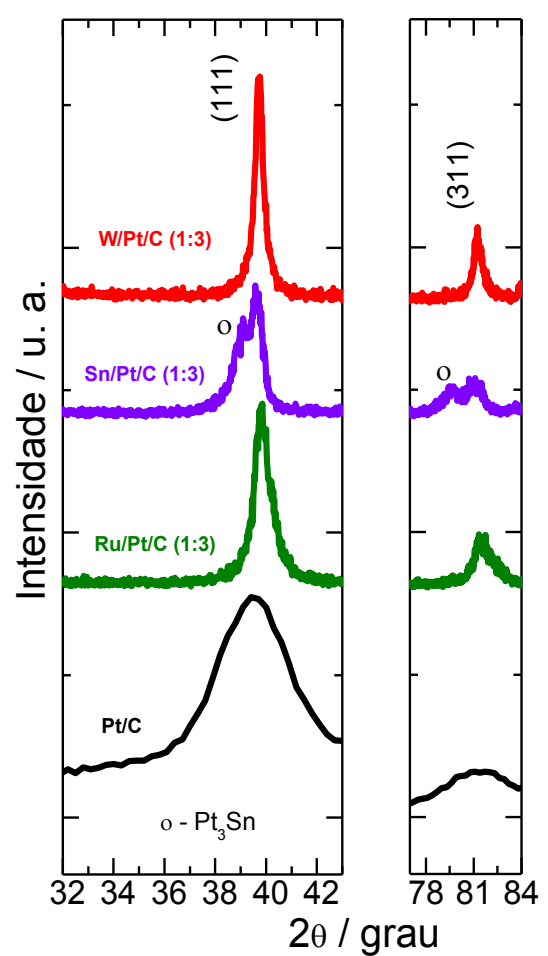

Fonte: Adaptado de A. C. QUEIROZ, et al., Applied Catalysis B: Environmental, v. 160-161, p. 423-435, 2014. 
Tabela 1 - Composição atômica média e tamanho médio de cristalito e partícula obtido por EDS, DRX e MET para os bimetálicos investigados e Pt/C E-TEK 20\%.

\begin{tabular}{|c|c|c|c|c|c|}
\hline \multirow[b]{2}{*}{ Amostra } & \multicolumn{2}{|c|}{ X-EDS } & \multirow[b]{2}{*}{$\begin{array}{c}\text { TEM } \\
\text { Tamanho } \\
\text { médio de } \\
\text { partícula / } \\
\text { nm }\end{array}$} & \multicolumn{2}{|c|}{ XRD } \\
\hline & $\begin{array}{l}\text { Composição } \\
\text { atômica } \\
\text { - nominal } \\
\text { (M:Pt) }\end{array}$ & $\begin{array}{l}\text { Composição atômica } \\
\text { percentual - } \\
\text { como preparado } \\
(\mathrm{M}(\%): \mathrm{Pt}(\%))\end{array}$ & & $\begin{array}{l}\text { Tamanho } \\
\text { médio de } \\
\text { cristalito / } \\
\text { nm }\end{array}$ & $\begin{array}{c}\text { Parâmetro de } \\
\text { rede / nm }\end{array}$ \\
\hline $\mathrm{Sn} / \mathrm{Pt} / \mathrm{C}$ & $1: 3$ & $22: 78(1: 3,6)$ & 3,0 & 8,6 & $\begin{array}{c}0,3996\left(\mathrm{Pt}_{3} \mathrm{Sn}\right) \\
0,3926\end{array}$ \\
\hline $\mathrm{Ru} / \mathrm{Pt} / \mathrm{C}$ & $1: 3$ & $20: 80(1: 4)$ & 4,5 & 11,8 & 0,3911 \\
\hline $\mathrm{W} / \mathrm{Pt} / \mathrm{C}$ & $1: 3$ & $19: 81(1: 4,2)$ & 4,5 & 21,3 & 0,3922 \\
\hline $\mathrm{W} / \mathrm{Pt} / \mathrm{C}$ & $2: 3$ & $37: 63(1: 1,7)$ & 5,0 & 30,0 & 0,3922 \\
\hline $\mathrm{Pt} / \mathrm{C}$ & - & - & 2,5 & 2,8 & 0,3923 \\
\hline
\end{tabular}

Fonte: Adaptado de A. C. QUEIROZ, et al., Applied Catalysis B: Environmental, v. 160-161, p. 423-435, 2014.

\subsubsection{Experimentos de DEMS on-line para a Eletro-oxidação de Etanol, Acetaldeído e} CO Adsorvido sobre Ru/Pt/C, Sn/Pt/C e W/Pt/C

As correntes de oxidação de CO adsorvido (stripping de CO), e os sinais iônicos $m / z=22$ e $m / z=44$ associados à formação de $\mathrm{CO}_{2}$, estam apresentados na Figura 5(a,b,c) respectivamente. Menor potencial de oxidação de CO é observado para os materiais com Ru e Sn, o que é uma consequência da facilidade de oxidação de CO sobre estes materiais. Isto pode ser explicado pelo mecanismo bifuncional, em que os átomos de $\mathrm{Ru}$ ou $\mathrm{Sn}$ providenciam espécies oxigenadas para o acoplamento $\mathrm{CO}-\mathrm{O}$, como proposto anteriormente [55], além do efeito eletrônico resultante da interação dos metais oxofílicos com a platina. No caso do material W/Pt/C, é também observado um deslocamento negativo do potencial de início de oxidação de CO comparado com Pt/C. No entanto, este deslocamento não é tão pronunciado quanto aqueles observados para os eletrocatalisadores contendo $\mathrm{Ru}$ ou $\mathrm{Sn}$. Logo, parece que a formação de espécies 
oxigenadas "ativas" sobre $\mathrm{W}$, necessárias para a oxidação de $\mathrm{CO}$, toma lugar em menor extensão [56,57]. Em todos os casos, os sinais iônicos para $\mathrm{CO}_{2}$, medidos por DEMS, combinam com os perfis de corrente faradaica, sendo estes melhores para a determinação do potencial de onset, pois os sinais de corrente iônica são livres do fenômeno de carregamento da dupla camada. É válido notar que os picos para a oxidação de CO sobre materiais de $\mathrm{Ru} / \mathrm{Pt} / \mathrm{C}$ (1:3) e $\mathrm{Sn} / \mathrm{Pt} / \mathrm{C}$ (1:3) são mais amplos do que para $\mathrm{Pt} / \mathrm{C}$. Isto pode ser atribuído à presença de cristalitos com diferentes tamanhos para os materiais bimetálicos. Menores cristalitos têm alto centro de banda-d, levando a uma adsorção mais forte metal-CO, o que diminui a taxa de oxidação de $\mathrm{CO}$ a baixos potenciais. Cristalitos maiores possuem mais baixo centro de banda-d, o que conduz a uma adsorção metal-CO mais fraca, e portanto, um stripping de CO facilitado em mais baixos potenciais [58]. Cristalitos com diferentes tamanhos também tem diferentes números de defeitos, que influenciam a atividade para ativação da água (formando espécies oxigenadas adsorvidas), necessária para o acoplamento CO-O [59]. Adicionalmente, esta ampla característica pode também ser uma consequência de um valor não homogêneo para a distância entre sítios ativos de Pt e Ru ou Sn, que afetam a eletro-oxidação de CO. Todas estas variáveis podem ter uma importante contribuição influenciando a taxa de eletrooxidação de $\mathrm{CO}$ adsorvido, produzindo um pico amplo de corrente como uma função do potencial. 
Figura 5 - (a) Stripping de CO, potencial de adsorção de $0,1 \mathrm{~V}$, eletrólito livre de $\mathrm{O}_{2}$, inserção de detalhes dos fragmentos iônicos de massas; (b) $\mathrm{m} / z=22\left(\mathrm{CO}_{2}{ }^{+}\right)$ e (c) $\mathrm{m} / z=44\left(\mathrm{CO}_{2}{ }^{2+}\right)$. Medidas realizadas em $\mathrm{H}_{2} \mathrm{SO}_{4} 0,5 \mathrm{~mol} \mathrm{~L}^{-1}$ e velocidade de varredura de $0,01 \mathrm{~V} \mathrm{~s}^{-1}$.

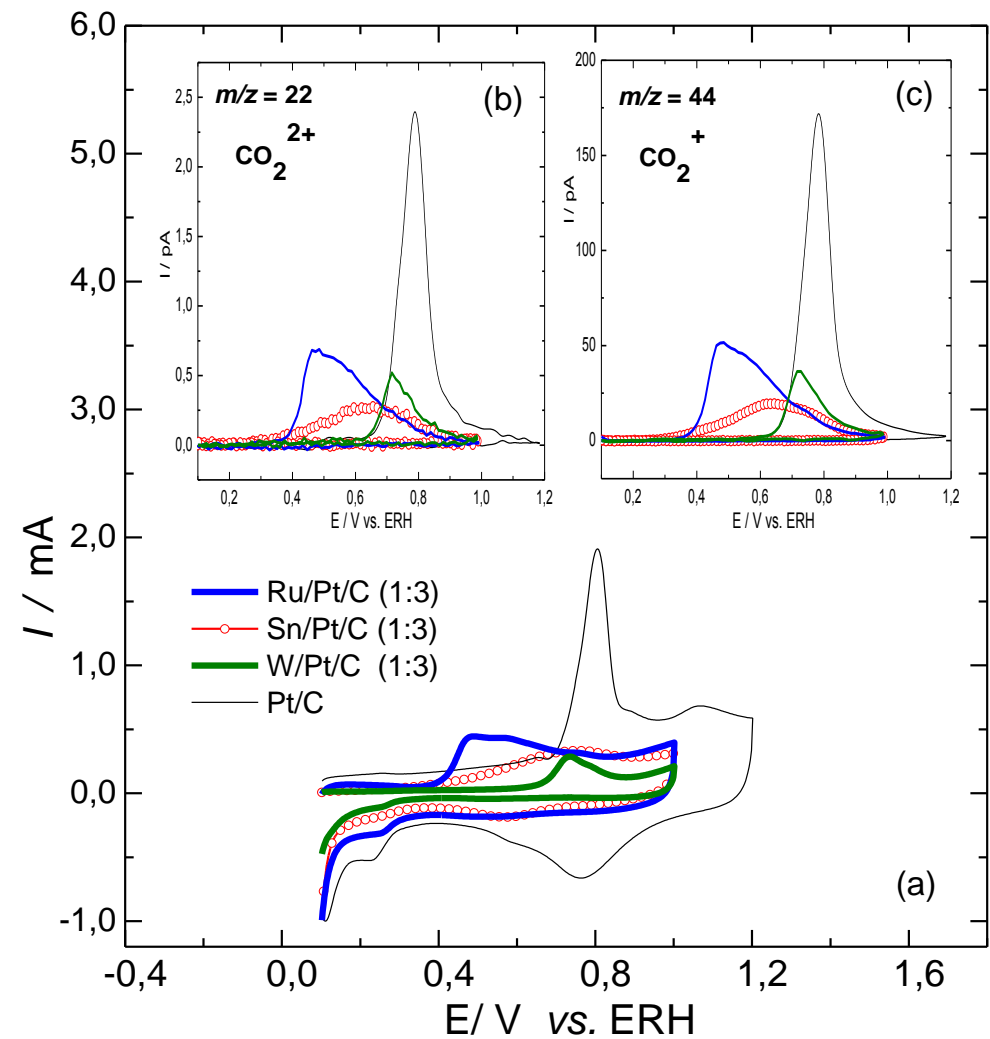

Fonte: Adaptado de A. C. QUEIROZ, et al., Applied Catalysis B: Environmental, v. 160-161, p. 423-435, 2014.

Os voltamogramas cíclicos (CVs) registrados para a eletro-oxidação de etanol catalisada pelos materiais $\mathrm{Ru} / \mathrm{Pt} / \mathrm{C}, \mathrm{Sn} / \mathrm{Pt} / \mathrm{C}$ e W/Pt/C sob condições de eletrólito estagnante em solução de etanol $0,1 \mathrm{~mol} \mathrm{~L}^{-1}+\mathrm{H}_{2} \mathrm{SO}_{4} 0,5 \mathrm{~mol} \mathrm{~L}{ }^{-1}$, são apresentados na Figura 6(a). A curva obtida para $\mathrm{Pt} / \mathrm{C}$ foi incluída para comparação. Como pode ser observado, o potencial de início da reação de eletro-oxidação de etanol obtido para $\mathrm{Sn} / \mathrm{Pt} / \mathrm{C}(c a .0,3 \mathrm{~V})$ é menor do que para os outros eletrocatalisadores. Abaixo do potencial de onset, a reação parece ser inibida por intermediários adsorvidos tais como espécies CO e $\mathrm{CH}_{\mathrm{x}}$, devido à adsorção dissociativa do etanol. Acima de $0,5 \mathrm{~V}$, a taxa da reação aumenta consideravelmente devido à oxidação destes intermediários adsorvidos. Para todos os materiais investigados, pode ser observado um pico duplo na varredura no sentido 
positivo e, em altos potenciais, a corrente cai devido à competição entre a adsorção de etanol e a ativação das moléculas de água formando espécies Pt-O. Na varredura no sentido negativo, a reação permanece inibida até a eletro-redução de Pt-O em 0,85 V e, então, aumenta bruscamente devido à liberação dos sítios metálicos ativos de Pt para a adsorção de etanol [20]. Após isto, a reação diminui em potenciais mais negativos devido ao "re-envenenamento" da superfície do catalisador por espécies $\mathrm{CO}$ e $\mathrm{CH}_{\mathrm{x}}$.

A determinação dos produtos da eletro-oxidação de etanol foi realizada utilizando a técnica de DEMS on-line. A formação de $\mathrm{CO}_{2}$ foi monitorada usando o sinal $m / z=22$, que corresponde ao sinal iônico da molécula duplamente ionizada $\left[\mathrm{CO}_{2}{ }^{2+}\right]$, e para a formação de acetaldeído utilizou-se o sinal $m / z=29$, que corresponde ao fragmento $\left[\mathrm{CHO}^{+}[60,61]\right.$. Os sinais de massa dos experimentos potenciodinâmicos de DEMS online para a eletro-oxidação de etanol, catalisada pelos diferentes materiais investigados, estão apresentados na Figura 6(b-d). Como pode ser observado, na varredura no sentido positivo, o sinal do $\mathrm{CO}_{2}$ (Figura 6(b)) passa por um pico e, então, diminui no intervalo de potencial de alta cobertura de Pt-O. Adicionalmente, pode ser observado que o onset e a magnitude do sinal de massa de $\mathrm{CO}_{2}$ seguem a tendência observada nas medidas de stripping de $\mathrm{CO}$, indicando similar tendência de cobertura de $\mathrm{CO}$, quando é originado da adsorção dissociativa de etanol. Logo, os sítios para adsorção de CO (proveniente do CO dissolvido) ou formação de CO (da quebra da ligação C-C do etanol) segue a mesma ordem de atividade. Na varredura no sentido negativo, a formação de $\mathrm{CO}_{2}$ é totalmente suprimida para todos os casos. Como discutido em trabalhos prévios [24,62,63], este comportamento indica que a formação de $\mathrm{CO}_{2}$ durante a varredura no sentido positivo é associada à oxidação de intermediários adsorvidos, tais como $\mathrm{CO}$ e $\mathrm{CH}_{\mathrm{x}}$, formados da quebra da ligação $\mathrm{C}-\mathrm{C}$ em baixos potenciais. A ausência de $\mathrm{CO}_{2}$ na varredura no sentido negativo indica que a quebra da ligação $\mathrm{C}-\mathrm{C}$ não ocorre em potencias mais elevados. Isto 
pode ser suportado em trabalho prévio [24], onde foi sugerido que, em baixos potenciais, a etapa determinante de velocidade é a oxidação de $\mathrm{CO}_{\mathrm{ad}} \mathrm{e}$, em mais altos potenciais, a etapa determinante de velocidade é a quebra da ligação $\mathrm{C}-\mathrm{C}$ (formação de $\mathrm{CO}_{\mathrm{ad}}$ ). Isto explica a formação de $\mathrm{CO}_{2}$ na varredura no sentido positivo, e a sua ausência na varredura no sentido negativo.

A Análise da Figura 6, mostra ainda que o sinal de acetaldeído (Figura 6(c)) segue a tendência da corrente faradaica de eletro-oxidação de etanol. Além disso, pode ser observado também que a razão dos sinais $\mathrm{m} / \mathrm{z}=22 \mathrm{ou} \mathrm{m} / \mathrm{z}=44 / \mathrm{m} / \mathrm{z}=29$ é mais alta para $\mathrm{Ru} / \mathrm{Pt} / \mathrm{C}$, o que indiretamente evidência eficiência de corrente superior para formação de $\mathrm{CO}_{2}$ [64]. 
Figura 6 - (a) Perfis voltamétricos para a eletro-oxidação de etanol $0,1 \mathrm{~mol} \mathrm{~L}^{-1}$ sobre os bimetálicos investigados comparado com Pt/C E-TEK $20 \%$ a $25^{\circ} \mathrm{C}$. Velocidade de varredura de $0,01 \mathrm{~V} \mathrm{~s}^{-1}$; (b) fragmento iônico de massa $\mathrm{m} / z=$ $22\left(\mathrm{CO}_{2}\right)$, inserção de detalhes (c) $\mathrm{m} / \mathrm{z}=29$ e (d) $\mathrm{m} / \mathrm{z}=44$, obtidos no experimento de DEMS on-line. $\mathrm{H}_{2} \mathrm{SO}_{4} 0,5 \mathrm{~mol} \mathrm{~L}^{-1}$.
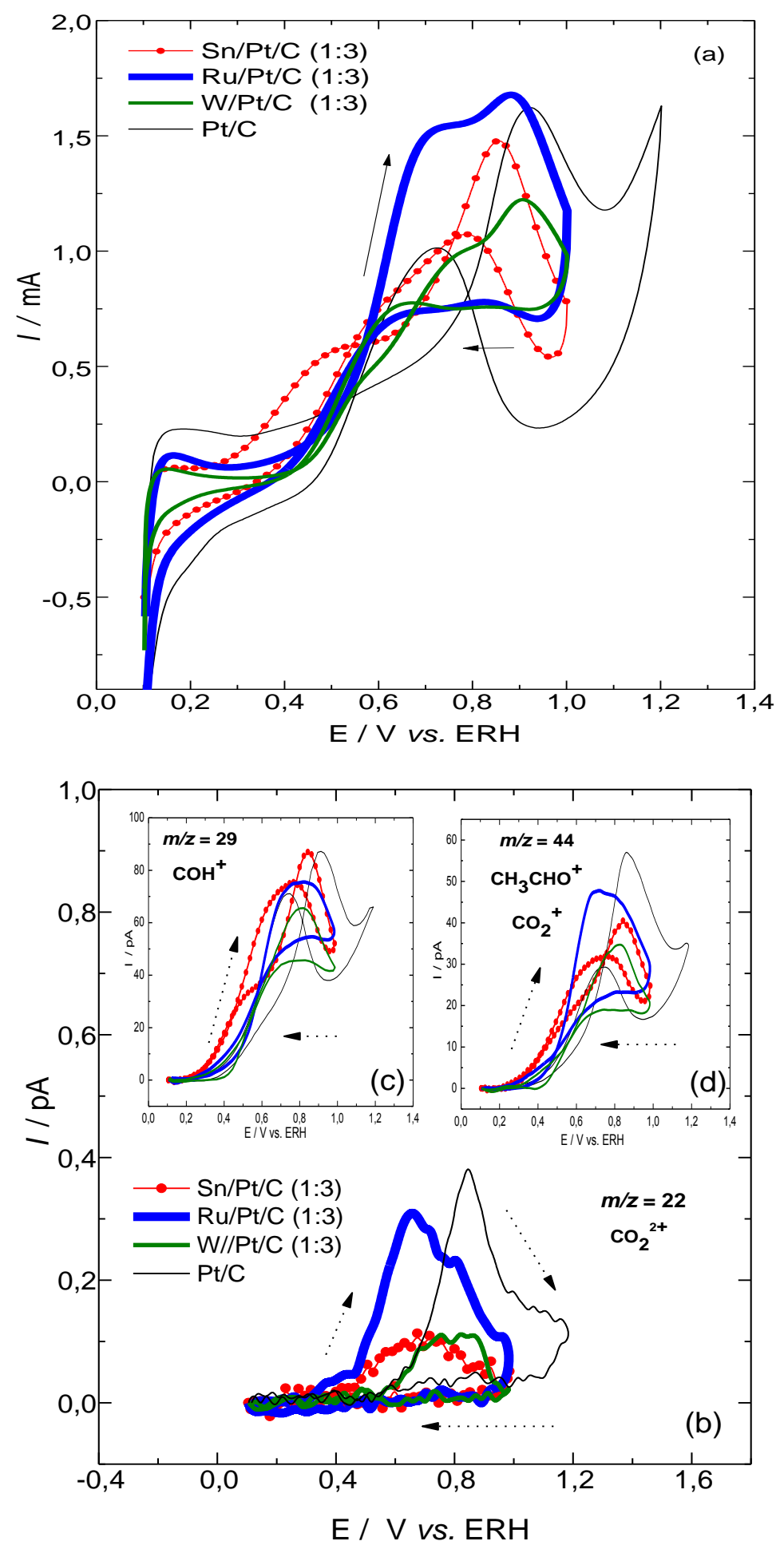

Fonte: Adaptado de A. C. QUEIROZ, et al., Applied Catalysis B: Environmental, v. 160-161, p. 423-435, 2014. 
As eficiências médias de corrente para formação de $\mathrm{CO}_{2}$ para os diferentes eletrocatalisadores foram calculadas integrando-se um ciclo voltamétrico completo para a eletro-oxidação de etanol, sendo que os resultados obtidos estão apresentados na Tabela 2. Pode ser notado o valor mais alto para $\mathrm{Ru} / \mathrm{Pt} / \mathrm{C}(1: 3)(16,6 \%)$, sendo este seguido por $\mathrm{Pt} / \mathrm{C}(13,0 \%), \mathrm{Sn} / \mathrm{Pt} / \mathrm{C}(1: 3)(7,4 \%)$ e W/Pt/C (1:3) (7,3\%). É importante mencionar que os altos valores de eficiências de correntes obtidos neste trabalho, em comparação àqueles obtidos na literatura [24,52], são devidos ao uso de uma célula com eletrólito estagnante acoplada ao DEMS, e elevada carga de pó do eletrocatalisador no eletrodo. O eletrólito estagnante permite a re-adsorção de espécies intermediárias da reação, e a camada catalítica mais espessa aumenta o tempo de residência no interior da camada, ambos contribuindo com o aumento na eficiência de conversão à $\mathrm{CO}_{2}$. Medidas potenciostáticas também foram realizadas na mesma solução para a EOR (Ethanol Oxidation Reaction) catalisada pelos diferentes eletrocatalisadores. As correntes faradaicas, apresentadas na Figura 7(a) mostram uma tendência similar na atividade àquela obtida em medidas potenciodinâmicas, com $\mathrm{Sn} / \mathrm{Pt} / \mathrm{C}(1: 3)$ apresentando maiores correntes a 0,5 V e 0,6 V (mais baixo potencial de onset nas curvas CVs). Os sinais de DEMS para $\mathrm{m} / z=29$ e $\mathrm{m} / \mathrm{z}$ $=44$, apresentados na Figura 7(b, c) respectivamente, também mostram que estes maiores valores de corrente, a baixos potenciais, são devidos à formação de acetaldeído, sendo este o produto majoritário. Para todos os casos, uma diminuição da corrente pode ser observada, visto que eles caem como uma função do tempo. Este resultado pode estar associado ao envenenamento da superfície do eletrocatalisador por espécies adsorvidas $\mathrm{CO}$ e $\mathrm{CH}_{\mathrm{x}}$ durante o curso da EOR, além da ausência de reagente próximo a superfície eletrocatalítica, condição experimental sem controle por transporte de massa. Por outro lado, W/Pt/C apresentou a mais baixa taxa de desativação, o que é associado à mais baixa atividade para a dissociação da ligação C-C. 
Figura 7 - (a) Curvas cronoamperométricas obtidas em experimentos de DEMS on-line para a reação de eletro-oxidação de etanol $0,1 \mathrm{~mol} \mathrm{~L}^{-1}$, seguindo os fragmentos iônicos de massa (b) $m / z=29$ e (c) $m / z=44$. $\mathrm{H}_{2} \mathrm{SO}_{4} 0,5 \mathrm{~mol} \mathrm{~L}^{-1}$.
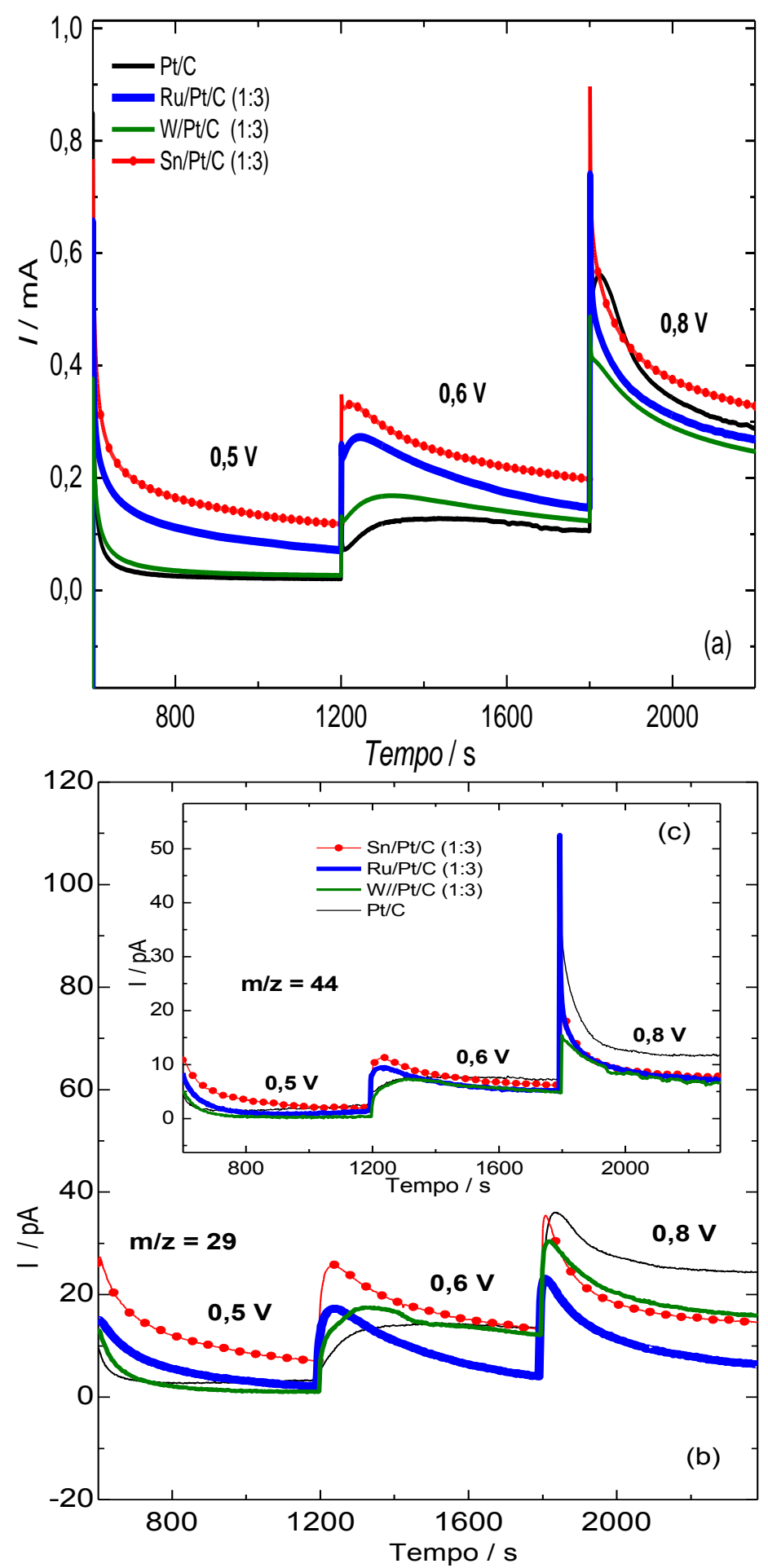

Fonte: Adaptado de A. C. QUEIROZ, et al., Applied Catalysis B: Environmental, v. 160-161, p. 423-435, 2014. 
Tabela 2 - Eficiência média de corrente (Aq) para a formação de $\mathrm{CO}_{2}$, durante a eletrooxidação de etanol catalisada pelos diferentes eletrocatalisadores investigados, obtida em solução $0,1 \mathrm{~mol} \mathrm{~L}^{-1}$ etanol $+0,5 \mathrm{~mol} \mathrm{~L}^{-1} \mathrm{H}_{2} \mathrm{SO}_{4}$, integrando-se um ciclo voltamétrico completo.

\begin{tabular}{ccc}
\hline Eletrocatalisadores & $\mathbf{K}^{*}{ }_{\mathbf{2 2}}$ & $\mathbf{A}_{\mathbf{q}}(\mathbf{C O} \mathbf{2})$ \\
\hline $\mathbf{S n} / \mathbf{P t} / \mathbf{C}(\mathbf{1 : 3})$ & $3,710^{-6}$ & $7,4 \%$ \\
\hline $\mathbf{S n} / \mathbf{P t} / \mathbf{C}(\mathbf{2 : 3})$ & $3,510^{-6}$ & $7,3 \%$ \\
\hline $\mathbf{R u} / \mathbf{P t} / \mathbf{C ~ ( 1 : 3 )}$ & $3,710^{-6}$ & $16,6 \%$ \\
\hline $\mathbf{W} / \mathbf{P t} / \mathbf{C ~ ( 1 : 3 )}$ & $3,610^{-6}$ & $7,3 \%$ \\
\hline $\mathbf{W} / \mathbf{P t} / \mathbf{C}(\mathbf{2 : 3})$ & $3,810^{-6}$ & - \\
\hline $\mathbf{P t} / \mathbf{C}$ & $4,310^{-6}$ & $13,0 \%$ \\
\hline
\end{tabular}

Fonte: Adaptado de A. C. QUEIROZ, et al., Applied Catalysis B: Environmental, v. 160-161, p. 423-435, 2014.

Medidas de DEMS foram também realizadas a fim de investigar o efeito do aumento da quantidade de $\mathrm{Sn}$ e $\mathrm{W}$ sobre a distribuição dos produtos reacionais. Os resultados obtidos para $\mathrm{Sn} / \mathrm{Pt} / \mathrm{C}$, apresentados na Figura 8(a), mostram que o aumento do teor de Sn reduziu a corrente faradaica para a eletro-oxidação de etanol, sendo este seguido proporcionalmente pelos sinais iônicos $m / z=22\left(\mathrm{CO}_{2}\right), 29$ (acetaldeído) e 44 $\left(\mathrm{CO}_{2}\right.$ e acetaldeído) mostrados na Figura 8(b-d)) respectivamente. Isto pode ser associado ao número reduzido de sítios de Pt que são ativos para a eletro-oxidação de etanol, e um aumento no número de átomos de Sn sobre a superfície da nanopartícula, que são ativos somente para a ativação (ou quebra) da água. Consequentemente, como a corrente faradaica de eletro-oxidação de etanol é proporcionalmente seguida pelos sinais de massa de $\mathrm{CO}_{2}$ e acetaldeído, pode ser assumido que a proporção entre os caminhos paralelos $\mathrm{C}_{1}$ e $\mathrm{C}_{2}$ para a eletro-oxidação de etanol é inalterada com a variação do teor de $\mathrm{Sn}$. 
Figura 8 - (a) Perfis voltamétricos para a eletro-oxidação de $0,1 \mathrm{~mol} \mathrm{~L}^{-1}$ de etanol sobre $\mathrm{Sn} / \mathrm{Pt} / \mathrm{C}(1: 3)$ e $\mathrm{Sn} / \mathrm{Pt} / \mathrm{C}(2: 3)$ a $25^{\circ} \mathrm{C}$ em solução de $\mathrm{H}_{2} \mathrm{SO}_{4} 0,5 \mathrm{~mol} \mathrm{~L}^{-1}$ e velocidade de varredura de $0,01 \mathrm{~V} \mathrm{~s}^{-1}$; fragmento iônico de massa (b) $\mathrm{m} / \mathrm{z}=$ $22\left(\mathrm{CO}_{2}\right)$, inserção de detalhes dos fragmentos iônicos de massa (c) $\mathrm{m} / z=29$ (acetaldeído) e (d) $\mathrm{m} / z=44\left(\mathrm{CO}_{2}+\right.$ acetaldeído).
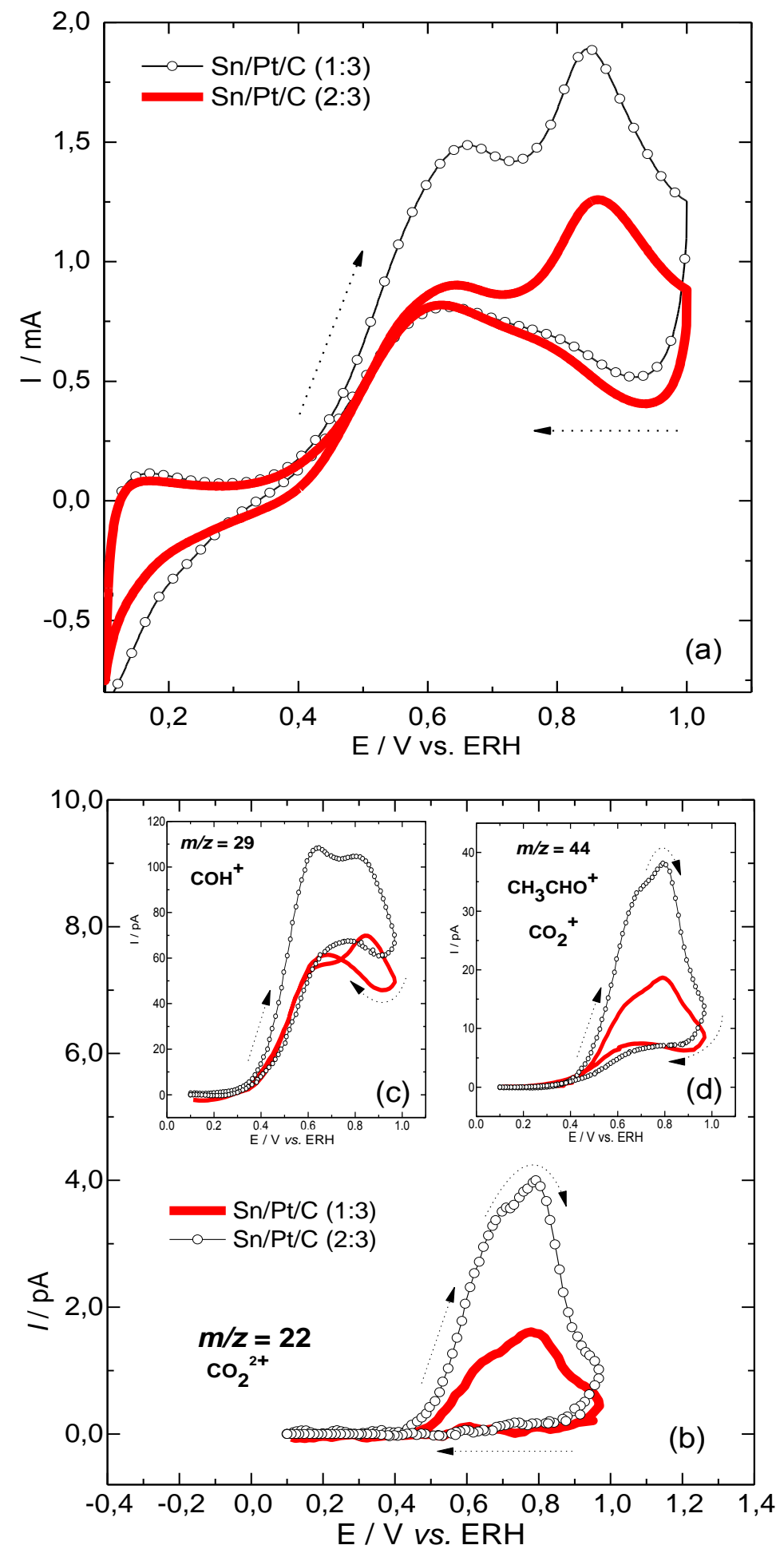

Fonte: Adaptado de A. C. QUEIROZ, et al., Applied Catalysis B: Environmental, v. 160-161, p. 423-435, 2014. 
A alteração no teor de W no eletrocatalisador W/Pt/C apresentou um importante resultado, conforme pode ser observado na Figura 9(a) o aumento no teor de W no material W/Pt/C é acompanhado por uma redução da corrente faradaica para a eletrooxidação de etanol, e esta é seguida por uma diminuição no sinal iônico $\mathrm{m} / z=29$ (Figura 9(c)). No entanto, esta redução na corrente faradaica não é proporcionalmente acompanhada pelos sinais iônicos $m / z=22$ e $m / z=44$ conforme apresentado na Figura 9(b, d). Ao invés disso, o sinal de massa para $\mathrm{CO}_{2}(m / z=22)$ é completamente suprimido (ou pelo menos não detectável) para o eletrocatalisador com maior quantidade de W (isto resulta em uma eficiência média de corrente faradaica para formação de $\mathrm{CO}_{2}$ igual a zero). Como mencionado acima, a reação de eletro-oxidação de etanol pode envolver etapas de adsorção de etanol, desprotonação, quebra da ligação C-C, e adição de oxigênio para formar $\mathrm{CO}_{2}$. Assim, sobre o eletrocatalisador W/Pt/C (2:3), aparentemente, as etapas de adsorção e desprotonação, formando hidrogênio adsorvido, continuam a ocorrer, mas a formação de espécies reativas tais como $\mathrm{CH}_{2} \mathrm{CHO}_{\text {ads }}$ ou $\mathrm{CH}_{2} \mathrm{CH}_{2} \mathrm{O}_{\text {ads, }}$, sugerida na Referência [33], pode não acontecer, inibindo ou desacelerando a etapa de quebra da ligação C-C. A inibição da quebra da ligação C-C pode também ser evidenciada indiretamente pela ausência do sinal iônico $m / z=15$, que corresponde à formação de metano, para $\mathrm{Pt} / \mathrm{C}$ e $\mathrm{Ru} / \mathrm{Pt} / \mathrm{C}$, a formação de metano foi observada em baixos potenciais devido a eletro redução de espécies adsorvidas com um átomo de carbono, tais $\operatorname{como~}^{\mathrm{CH}_{\mathrm{x}}}$ e CO. Portanto, a não detecção do metano para W/Pt/C (2:3) evidencia indiretamente a não ocorrência da adsorção dissociativa de etanol sobre a superfície deste eletrocatalisador (ou pelo menos uma taxa insignificante de dissociação). Isto também confirma a não ocorrência (ou uma taxa muito baixa) da quebra da ligação C-C sobre este material, inibindo a formação de espécies envenenadoras $\mathrm{CH}_{\mathrm{x}}$ e $\mathrm{CO}$. 
Figura 9 - (a) Perfis voltamétricos para a eletro-oxidação de $0,1 \mathrm{~mol} \mathrm{~L}^{-1}$ de etanol sobre W/Pt/C (1:3) e W/Pt/C (2:3) a $25^{\circ} \mathrm{C}$ em solução de $\mathrm{H}_{2} \mathrm{SO}_{4} 0,5 \mathrm{~mol} \mathrm{~L}^{-1} \mathrm{e}$ velocidade de varredura de $0,01 \mathrm{~V} \mathrm{~s}^{-1}$; fragmentos iônicos de massa (b) $\mathrm{m} / \mathrm{z}=$ $22\left(\mathrm{CO}_{2}\right)$, inserção de detalhes dos fragmentos iônicos de massa (c) $m / z=29$ (acetaldeído) e (d) $\mathrm{m} / z=44\left(\mathrm{CO}_{2}+\right.$ acetaldeído).
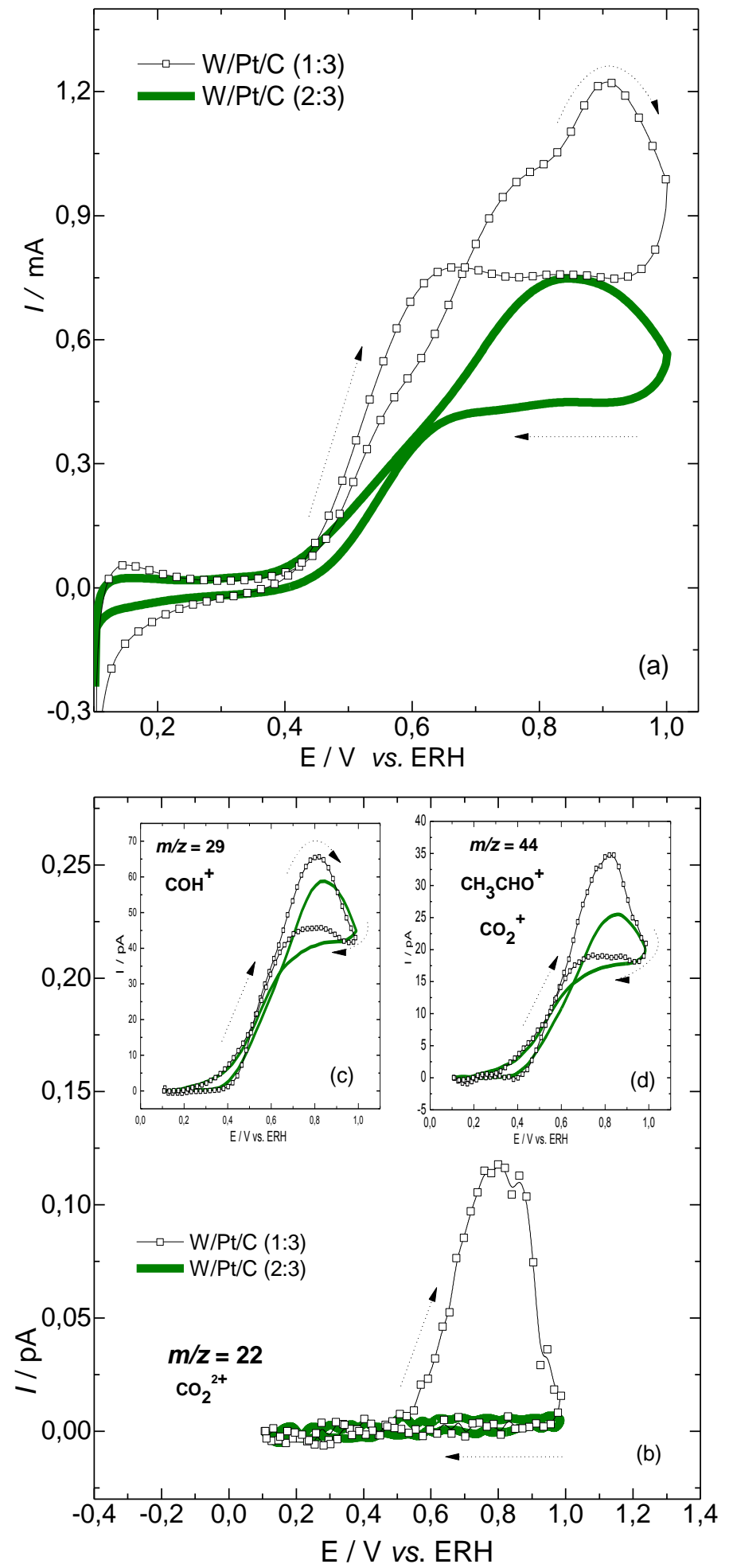

Fonte: Adaptado de A. C. QUEIROZ, et al., Applied Catalysis B: Environmental, v. 160-161, p. 423-435, 2014 
A atividade do eletrocatalisador W/Pt/C (2:3) para a eletro-oxidação de acetaldeído também foi investigada, uma vez que este material não catalisa a EOR formando $\mathrm{CO}_{2}$. A Figura 10(a) mostra os voltamogramas cíclicos para a eletro-oxidação de acetaldeído catalisada pelos materiais W/Pt/C (2:3) e Pt/C em 0,1 mol L-1 acetaldeído $+0,5 \mathrm{~mol} \mathrm{~L}^{-1} \mathrm{H}_{2} \mathrm{SO}_{4}$, que foram registrados durante os experimentos de voltametria cíclica no equipamento de DEMS on-line. As curvas de eletro-oxidação de etanol sobre ambos materiais foram adicionadas para comparação. Como pode ser notado, $\mathrm{Pt} / \mathrm{C}$ é ativo para a eletro-oxidação de etanol e acetaldeído e a formação de $\mathrm{CO}_{2}$ é claramente vista para ambos os casos (Figura 10(b, c)). Para o eletrocatalisador W/Pt/C (2:3), pode ser observada uma corrente faradaica para a eletro-oxidação de etanol, mas sem formação de $\mathrm{CO}_{2}$, como apresentado na Figura 9(b). Por outro lado, este material não foi ativo para a eletro-oxidação de acetaldeído (ausência de corrente faradaica) e, como consequência, não há sinal para $\mathrm{CO}_{2}($ Figura $10(\mathrm{~b}, \mathrm{c}))$. Assim, pode ser afirmado que o material W/Pt/C (2:3) é inativo para a quebra da ligação C-C na molécula de etanol e totalmente inativo para a eletro-oxidação de acetaldeído (ao menos inativo para a eletro-oxidação de acetaldeído pelo caminho $\mathrm{C}_{1}$ ). A eletro-oxidação de etanol e de seus produtos intermediários sobre materiais compostos por Pt/C foram também investigados por outros pesquisadores $[65,66]$, onde no primeiro foi mostrado a dependência do aumento da atividade eletrocatalitica de Pt para a eletro-oxidação de etanol, acetaldeído e ácido acético em função do teor de Sn e da temperatura de operação, os resultados mostraram maior desempenho para a EOR para o catalisador com maior teor de Sn operando em baixa temperatura. Enquanto no segundo trabalho foi determinado um método de preparacão promissor para catalisadores ternários de Pt-Sn-Rh que catalisam a reação de oxidação de etanol com alta atividade e seletividade para formação de $\mathrm{CO}_{2}$, baseado no método poliol modificado e seguido por tratamento térmico em atmosfera redutora. 
Figura 10 - (a) Perfis voltamétricos e sinais de correntes iônicas para (b) $\mathrm{m} / z=44\left(\mathrm{CO}_{2}\right.$ + acetaldeído) e (c) $\mathrm{m} / z=22\left(\mathrm{CO}_{2}\right)$ obtidos durante medidas de DEMS para a eletro-oxidação de etanol e acetaldeído catalisada por W/Pt/C (2:3) e Pt/C em $0,1 \mathrm{~mol} \mathrm{~L}^{-1}$ de $\mathrm{CH}_{3} \mathrm{CHO}$ ou $\mathrm{CH}_{3} \mathrm{CH}_{2} \mathrm{OH}$ e $0,5 \mathrm{~mol} \mathrm{~L}^{-1}$ de $\mathrm{H}_{2} \mathrm{SO}_{4}$ a $25^{\circ} \mathrm{C}$ e velocidade de varredura de $0,01 \mathrm{~V} \mathrm{~s}^{-1}$.

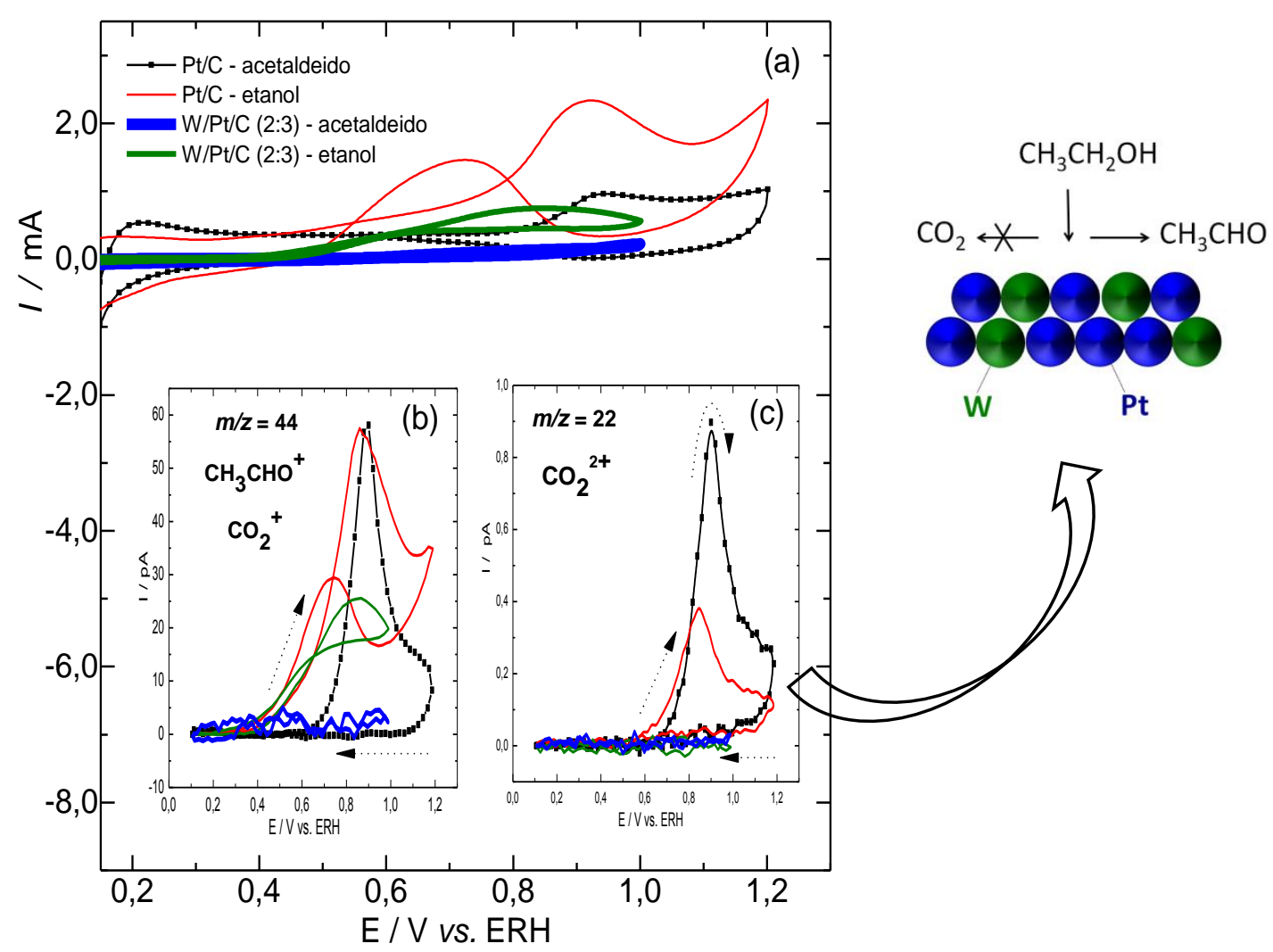

Fonte: Adaptado de A. C. QUEIROZ, et al., Applied Catalysis B: Environmental, v. 160-161, p. 423-435, 2014.

\subsubsection{Experimentos para a Eletro-oxidação de Hidrogênio sobre W/Pt/C}

De acordo com os resultados obtidos de um ponto de vista prático, como W/Pt/C

(2:3) foi inativo para a eletro-oxidação de acetaldeído e esta molécula pode ser um subproduto da desidrogenação do etanol, o material W/Pt/C (2:3) foi investigado como eletrocatalisador para a reação de eletro-oxidação de hidrogênio na ausência e na presença de acetaldeído no eletrólito. A Figura 11 mostra as curvas em eletrodo de disco rotatório (RDE) obtidas a $1600 \mathrm{rpm}$ (varredura linear (a) e curvas de cronoamperometria em $0,1 \mathrm{~V}$ (b)) para HOR (Hydrogen Oxidation Reaction) catalisada por W/Pt/C (2:3) e Pt/C 
(incluída para comparação). As análises de RDE a 1600 rpm e curvas de cronoamperometria revelaram superior atividade eletrocatalítica de Pt/C. De acordo com as curvas do tipo "vulcão" para a eletro-oxidação ou desprendimento de $\mathrm{H}_{2}$, Pt é mais ativa do que $\mathrm{W}$ [67] e, portanto, $\mathrm{Pt} / \mathrm{C}$ parece ser mais ativa do que W/Pt/C (2:3) para a HOR devido ao maior número de átomos de Pt na superfície da partícula e devido ao efeito eletrônico do centro de banda-d da Pt não ser beneficiado com W. Na presença de acetaldeído no eletrólito, Pt/C mostrou uma significativa redução nas correntes faradaicas em RDE e cronoamperometria. Por outro lado, W/Pt/C (2:3) apresentou uma ligeira diminuição na corrente para o RDE e somente uma pequena redução na medida potenciostática. Este resultado pode ser atribuído ao envenenamento da superfície da Pt/C devido à adsorção dissociativa de moléculas de acetaldeído, produzindo espécies adsorvidas de $\mathrm{CO}$ e $\mathrm{CH}_{\mathrm{x}}$, que não sofrem eletro-oxidação em potenciais menores do que ca. $0,75 \mathrm{~V}$. W/Pt/C (2:3) tem menor atividade para a HOR mas, por outro lado, não mostra desativação significativa devido à sua inatividade para quebrar a ligação $\mathrm{C}-\mathrm{C}$ evitando a formação indesejada de espécies $\mathrm{CO}$ e $\mathrm{CH}_{\mathrm{x}}$ sobre sua superfície. Portanto, W/Pt/C (2:3) seria um candidato promissor como eletrocatalisador do ânodo de células a combustível de hidrogênio indireto operando com etanol no processador de combustível externo, o que contribuirá para aumentar a corrente faradaica global. 
Figura 11 - (a) Perfis voltamétricos para a eletro-oxidação de $\mathrm{H}_{2}$ na ausência e na presença de $0,1 \mathrm{~mol} \mathrm{~L}^{-1}$ de acetaldeído. Velocidade de rotação do eletrodo de $1600 \mathrm{rpm}$ e velocidade de varredura de $0,01 \mathrm{~V} \mathrm{~s}^{-1}$; (b) curvas de cronoamperometria, permanecendo por $1800 \mathrm{~s}$ no potencial de $0,1 \mathrm{~V}$.

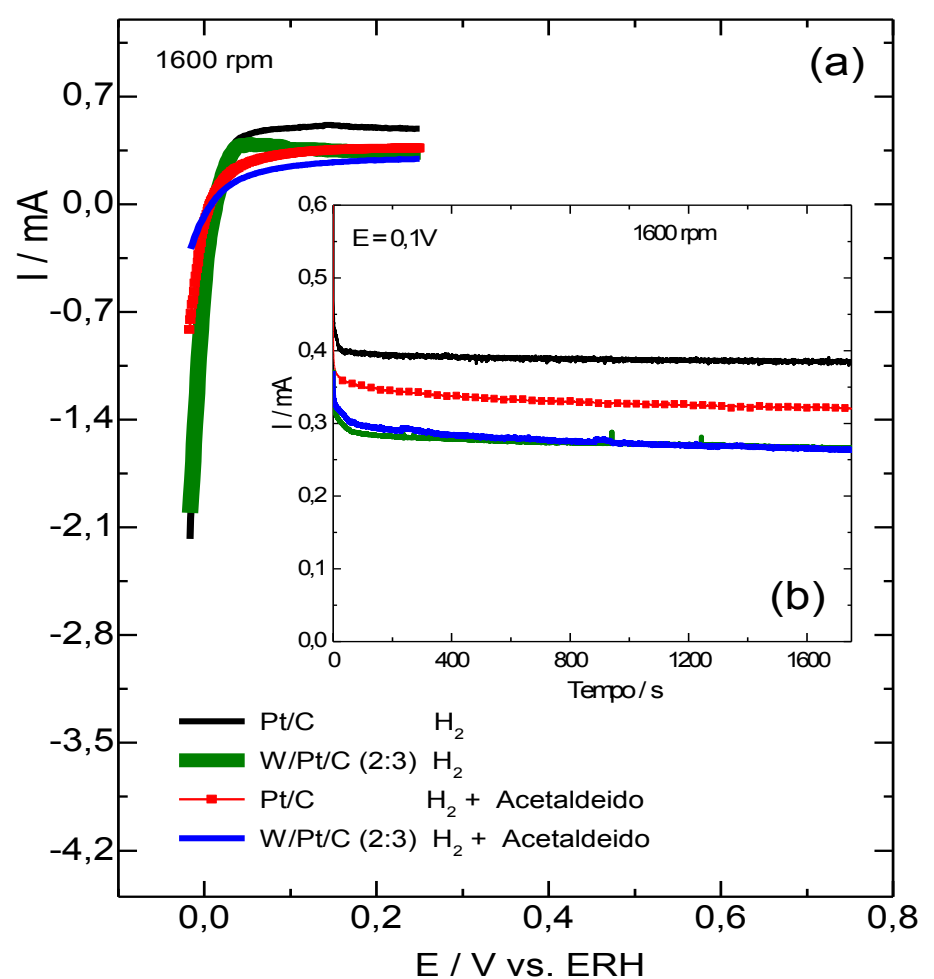

Fonte: Adaptado de A. C. Queiroz, et al., Applied Catalysis B: Environmental 160-161 (2014) 423-435. 


\section{PARTE 2: Identificação de Eletrocatalisadores para a Eletro-oxidação de Etanol Seletivos para a Rota $C_{1}$ em Temperatura Ambiente e Intermediária: Investigação por Espectrometria de Massas On-line.}

\subsection{INTRODUÇÃO}

Células a combustível alimentadas com $\mathrm{H}_{2}$ no ânodo e ar $\left(\mathrm{O}_{2}\right)$ no cátodo são uma opção promissora para a aplicação em carros elétricos, pois apresentam alta densidade de energia. As células alimentadas com combustíveis líquidos, tais como metanol e etanol, por outro lado, são convenientes para aplicação em dispositivos eletrônicos portáteis [11]. No entanto, como o metanol é um combustível tóxico, torna-se importante e necessário o desenvolvimento de células que utilizem combustíveis menos agressivos e economicamente viáveis. Neste sentido, o uso de etanol como combustível pode ser bastante conveniente em células a combustível de etanol direto (Direct Ethanol Fuel Cell - DEFC) $[18,68]$. Isto se soma ao fato deste combustível ser extremamente vantajoso para o Brasil, uma vez que toda a rede de produção e distribuição encontra-se montada. Ademais, o etanol é um combustível renovável, fator esse de grande valia para o desenvolvimento de uma economia sustentável. A importância do etanol esta relacionada não somente aos fatores já comentados anteriormente, mas também ao alto conteúdo energético, que corresponde a 12 elétrons por molécula para a total oxidação do etanol a $\mathrm{CO}_{2}[69-72]$.

A platina apresenta alta atividade eletrocatalítica e é utilizada como modelo para diversas reações eletroquímicas (oxidação e redução) devido às características de sua estrutura eletrônica [73,74]. Como discutido em trabalhos anteriores [75,76], a reatividade dos metais pode ser racionalizada em termos da posição do centro de energia da banda d, $\varepsilon_{d}$ ou densidade de estados ocupados próximos do nível de Fermi, o que 
comanda a força de adsorção de espécies reacionais intermediárias. Neste caso, Pt possui a maior atividade, pois apresenta um balanço mais próximo para tendências opostas de quebra e formação de ligações no adsorbato, principalmente quando átomos de carbono, oxigênio, nitrogênio e hidrogênio são envolvidos. Apesar disso, os valores de eficiências de eletro conversão de etanol a $\mathrm{CO}_{2}$ sobre platina ainda são muito baixos.

Visto que a eletro-oxidação total do etanol é bastante complexa, os eletrocatalisadores devem possuir composição e estrutura sofisticadas. Assim, pesquisadores têm trabalhado no sentido de desenvolver eletrocatalisadores eficientes que sejam capazes de oxidar etanol e seus intermediários parcialmente oxidados a $\mathrm{CO}_{2}$, além de serem estáveis por longos tempos de operação, ou seja, imunes a envenenamento [7784]. Sun e co-autores [62] investigaram a oxidação eletroquímica de etanol em um amplo intervalo de temperaturas usando DEMS. Os resultados evidenciaram um significativo efeito da concentração de etanol, potencial e temperatura sobre a eficiência de corrente para formação de $\mathrm{CO}_{2}$, sendo $90 \%$ de eficiência obtido para $0,001 \mathrm{~mol} \mathrm{~L}^{-1}(0,48 \mathrm{~V}$ e 100 $\left.{ }^{\circ} \mathrm{C}\right)$. Uma extrapolação feita para mais alta temperatura $\left(140^{\circ} \mathrm{C}\right)$ indica obtenção de $100 \%$ de eficiência de corrente para formação de $\mathrm{CO}_{2}$ usando maior concentração de etanol $(0,1$ mol L $\mathrm{L}^{-1}$ ). Tais resultados mostram um efeito importante da temperatura reacional sobre a eletro-oxidação total de etanol.

Tendo em vista a grande dificuldade da eletro-oxidação de etanol em temperatura ambiente e resultados promissores de eficiência em temperaturas acima de $100^{\circ} \mathrm{C}$, células a combustível de ácidos sólidos (Solid Acid Fuel Cells - SAFCs) podem ser uma alternativa promissora para a utilização direta do etanol. Este tipo de célula tem como eletrólito ácidos sólidos que possuem grupos oxiânions $\left(\mathrm{SO}_{4}{ }^{2-}, \mathrm{PO}_{4}{ }^{3-}, \mathrm{SeO}_{4}{ }^{2-}\right.$, $\mathrm{AsO}_{4}{ }^{3-}$ ) e carga balanceada por espécies iônicas, tais como $\mathrm{Cs}^{+}, \mathrm{Rb}^{+}, \mathrm{NH}_{4}{ }^{+}, \mathrm{K}^{+}$, possuindo a composição $\mathrm{MH}_{\mathrm{n}} \mathrm{XO}_{4}$, onde $\left(\mathrm{M}=\right.$ metal alcalino, $\mathrm{NH}_{4}$ e $\mathrm{X}=\mathrm{P}, \mathrm{S}, \mathrm{Se}$, As). Estes 
eletrólitos sofrem transição em temperaturas elevadas, e a fase desordenada resultante conduz à um aumento da condutividade protônica em várias ordens de magnitude [8587]. Entre os eletrólitos de ácidos sólidos, $\mathrm{CsH}_{2} \mathrm{PO}_{4}$ (Cesium Dihydrogen Phosphate CDP) é considerado o mais interessante, visto que, após alcançar a temperatura de transição de fase $\left(\sim 228^{\circ} \mathrm{C}\right)$, sua condutividade protônica aumenta da ordem de 4 vezes

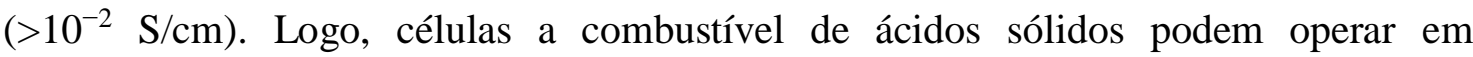
temperaturas intermediárias $\left(200-300^{\circ} \mathrm{C}\right)$, o que favorece o uso de combustíveis mais complexos do que hidrogênio, como é o caso do etanol.

No entanto, há alguns desafios para o uso deste eletrólito em células a combustível, como por exemplo, pode-se citar a desidratação do CDP que ocorre devido a alta temperatura de transição superprotônica deste material, conduzindo desta forma a polimerização dos ânions fosfatos e a consequente perda de água, o que conduz a perda de condutividade deste eletrólito $\left(\mathrm{CsH}_{2} \mathrm{PO}_{4}(\mathrm{~s}) \rightarrow \mathrm{CsPO}_{3(\mathrm{~s})}+\mathrm{H}_{2} \mathrm{O}_{(\mathrm{g})}\right)$, desta forma, se faz necessário umidificar este eletrólito (CDP) a partir de $140^{\circ} \mathrm{C}$ para evitar sua desidratação. Não obstante, a desidratação pode ser suprimida usando uma adequada pressão parcial de água, o que permite uma operação apropriada da célula a combustível [87-89]. Logo, células a combustível de ácidos sólidos possuem várias vantagens comparadas as células a combustível com Membrana Trocadora de Protons (Proton Exchange Membrane Fuel Cells - PEMFCs), cuja temperatura de operação não pode ultrapassar $100^{\circ} \mathrm{C}$, como exemplos pode-se citar a possibilidade de operar usando uma maior variedade de combustíveis, além da redução ou eliminação do uso de metais nobres nos eletrodos.

Não obstante, as rotas que a reação de eletro-oxidação de etanol seguirá nesta faixa de temperatura são pouco conhecidas. Uda e co-autores [88] investigaram o desempenho de uma Célula de Ácido Sólido alimentada com etanol e operando a $250^{\circ} \mathrm{C}$, usando um eletrocatalisador composto por Pt-Ru e integrando um catalisador reformador, 
$\mathrm{Cu}-\mathrm{ZnO} / \mathrm{Al}_{2} \mathrm{O}_{3}$, para álcool no compartimento do ânodo, e Pt como eletrocatalisador no cátodo. A densidade de potência foi próxima a $100 \mathrm{~mW} / \mathrm{cm}^{2}$. Estes resultados mostram o potencial desta abordagem para aumentar o desempenho global de células a combustível.

Shimada e colaboradores [90] analisaram a distribuição dos produtos reacionais para a eletro-oxidação de etanol em temperaturas intermediárias $\left(235-260^{\circ} \mathrm{C}\right)$ usando a técnica de cromatografia gasosa. CDP foi usado como eletrólito, sendo todos os experimentos realizados em uma meia célula e Pt/C foi empregada como catalisador. Estes autores concluíram que os principais produtos da eletro-oxidação de etanol foram $\mathrm{H}_{2}, \mathrm{CO}_{2}$ e $\mathrm{CH}_{4}$ com eficiência de corrente para formação de $\mathrm{CO}_{2}$ de $80 \%$. Por outro lado, a formação de produtos que seguem a via $\mathrm{C}_{2}$, tais como acetaldeído e ácido acético foi menor do que 5\%. Logo, a taxa de quebra da ligação C-C foi consideravelmente alta usando SAFC (maior do que 90\%) o que mostra a viabilidade do uso direto de etanol em células a combustível de altas temperaturas, como Células de Ácidos Sólidos. 


\subsection{OBJETIVOS}

O objetivo geral da segunda parte deste trabalho foi relacionado com o estudo da atividade do eletrocatalisador composto por $\mathrm{SnO}_{x} \mathrm{RuO}_{\mathrm{x}}-\mathrm{Pt} / \mathrm{C}(1: 1: 3)$ em diferentes condições experimentais (temperatura, concentração de etanol e eletrólito - condições de fluxo contínuo e estagnante), bem como a comparação destes resultados com àqueles obtidos para Pt/C. Assim, teve-se como meta o estudo da eletro-oxidação de etanol em eletrocatalisadores que favorecem a rota $\mathrm{C}_{1}$, visando aumentar a eficiência faradaica para formação de $\mathrm{CO}_{2}$.

Deste modo os objetivos foram definidos como:

- Síntese do eletrólito $\mathrm{CsH}_{2} \mathrm{PO}_{4}$ para a investigação da reação de eletro-oxidação de etanol a $245^{\circ} \mathrm{C}$;

- Síntese e estudo da estabilidade e da atividade eletrocatalítica de $\mathrm{SnO}_{\mathrm{x}} \mathrm{RuO}_{\mathrm{x}}-\mathrm{Pt} / \mathrm{C}$ (1:1:3) frente à eletro-oxidação de etanol em temperatura ambiente, utilizando $\mathrm{H}_{2} \mathrm{SO}_{4}$ aquoso como eletrólito (sob condições de fluxo contínuo e estagnante) e em temperatura intermediária $\left(245^{\circ} \mathrm{C}\right)$, utilizando o $\mathrm{CsH}_{2} \mathrm{PO}_{4}$ como eletrólito (sob condições de fluxo contínuo);

- Estudo quantitativo da distribuição dos produtos reacionais em experimentos de DEMS on-line, utilizando células eletroquímicas com eletrólito estagnante e em fluxo. 


\subsection{PROCEDIMENTO EXPERIMENTAL}

\subsubsection{Síntese e Caracterização das Nanopartículas}

Nesta segunda parte do trabalho, foi investigada a atividade de $\mathrm{SnO}_{\mathrm{x}} \mathrm{RuO}_{\mathrm{x}}-\mathrm{Pt} / \mathrm{C}$, uma combinação entre os bimetálicos $(\mathrm{Sn} / \mathrm{Pt} / \mathrm{C}$ e $\mathrm{Ru} / \mathrm{Pt} / \mathrm{C})$ que apresentaram maiores eficiências globais e menores potenciais de início de eletro-oxidação de etanol, além deste eletrocatalisador, os resultados para Pt/C (comercial - Alfa Aesar 50 wt.\% em carbono, número do lote C15W005) também foram incluídos para comparação. O eletrocatalisador trimetálico foi formado por $\mathrm{Ru}, \mathrm{Sn}$ e $\mathrm{Pt}$, representado aqui por $\mathrm{SnO}_{\mathrm{x}} \mathrm{RuO}_{\mathrm{x}}-\mathrm{Pt} / \mathrm{C}$, na razão atômica (Metal $1:$ Metal $\left._{2}: \mathrm{Pt}\right)$ de 1:1:3 adaptando-se um método publicado previamente [29]. Para a síntese, quantidades apropriadas de $\mathrm{RuCl}_{2}, \mathrm{SnCl}_{2}$ e $\mathrm{H}_{2} \mathrm{PtCl}_{2} \cdot 6 \mathrm{H}_{2} \mathrm{O}$ (SigmaAldrich) foram solubilizadas em água ultra pura, seguida pela adição de carbono de alta área superficial (Vulcan XC-72, Cabot, $250 \mathrm{~m}^{2} \mathrm{~g}^{-1}$ ). A suspensão resultante foi agitada e sonicada por 10 min em atmosfera de ar. Após isto, a solução foi agitada e aquecida a $80^{\circ} \mathrm{C}$ até completa evaporação do solvente presente no béquer. A amostra foi resfriada em ar e o pó impregnado foi submetido a tratamento térmico, conduzido em um forno tubular (MAITEC) sob atmosfera de argônio a $300^{\circ} \mathrm{C}$ por $1 \mathrm{~h}$, seguido pelo tratamento sob atmosfera de $\mathrm{H}_{2}$ a $300^{\circ} \mathrm{C}$ por $3 \mathrm{~h}$.

A composição atômica do eletrocatalisador resultante foi estimada por espectroscopia de energia dispersiva de raios-X (X-EDS), usando um Zeiss-Leica/LEO 440 modelo (LEO, UK). Características estruturais também foram investigadas por medidas de difração de Raios $\mathrm{X}(\mathrm{XRD})$ realizada usando um difratrômetro RIGAKU Ultima IV com radiação $\mathrm{Cu} K_{\alpha}(\lambda=1.54056 \AA)$, operado a $40 \mathrm{kV}$ e $40 \mathrm{~mA}$, e entre $20^{\circ}$ $100^{\circ}$, com uma taxa de velocidade de $0,3^{\circ} \mathrm{min}^{-1}$. O tamanho médio de cristalito foi 
estimado do pico (111) do padrão de difração da Pt usando a equação de Scherrer [45] e o parâmetro de rede (a) foi calculado pelo método dos mínimos quadrados [46].

\subsubsection{Preparação do Eletrólito e da Meia Célula de Ácido Sólido}

$\mathrm{O}$ eletrólito, composto pelo ácido sólido superprotônico $\mathrm{CsH}_{2} \mathrm{PO}_{4}$, foi sintetizado empregando o método de precipitação induzida usando soluções aquosas com quantidades estequiométricas de $\mathrm{CsCO}_{3}$ e $\mathrm{H}_{3} \mathrm{PO}_{4} \quad 85 \%$ adaptando-se um método publicado previamente $[87,88]$. O pó de $\mathrm{CsH}_{2} \mathrm{PO}_{4}$ foi precipitado adicionando-se a mistura $\mathrm{CsCO}_{3}+\mathrm{H}_{3} \mathrm{PO}_{4}$, após solubilizada em água, em um béquer contendo metanol, após esta etapa o pó resultante foi lavado e filtrado com $\mathrm{CH}_{3} \mathrm{OH}$, e então deixado em repouso por $24 \mathrm{~h}$ em metanol, após este tempo o sobrenadante foi descartado e um novo volume de $\mathrm{CH}_{3} \mathrm{OH}$ foi adicionado ao precipitado e sonicado por 30 segundos, a solução resultante foi deixada em repouso novamente por $24 \mathrm{~h}$. A seguir, o procedimento descrito acima foi repetido usando tolueno ao invés de metanol, após a retirada do sobrenadante de tolueno, o precipitado foi seco em estufa a $120^{\circ} \mathrm{C}$ por cerca de $12 \mathrm{~h}$.

A camada catalítica (eletrodo de trabalho) foi formada por uma mistura de 1:1 entre $\mathrm{CsH}_{2} \mathrm{PO}_{4}$ e $\mathrm{SnO}_{x} \mathrm{RuO}_{\mathrm{x}}-\mathrm{Pt} / \mathrm{C}$ (ou Pt/C). O contra eletrodo foi formado por uma mistura 1:1 de CDP e Pt/C 50 wt. \%. Em ambos os casos, a carga total de Pt foi aproximadamente $5,14 \mathrm{mg} \mathrm{cm}^{-2}$, sendo a área de cada eletrodo igual a $2,83 \mathrm{~cm}^{2}$. Um disco de aço inoxidável poroso, com tamanho médio de poro e porosidade de $40 \mu \mathrm{m}$ e 42-44\%, respectivamente, serviu como coletor de corrente/eletrodo de difusão de gás e funcionou, ainda, como suporte mecânico para a célula. As meias células foram preparadas prensando-se catalisador/eletrodo de trabalho + eletrólito $700 \mathrm{mg}+$ platina/eletrodo de referência e contra-eletrodo na forma de um disco. Uma camada de 
eletrocatalisador, uma camada de eletrólito, e uma camada de platina foram sequencialmente depositadas entre dois discos de papel de carbono (TGP-H-120, Fuel Cell Earth, LLC) que funcionaram como coletores de corrente e como substratos para as meias células. Após a deposição das camadas, a estrutura final foi prensada para promover adesão entre as camadas (4 toneladas/20 min). A seguir, os discos de aço inoxidáveis porosos foram adicionados a pastilha, esta estrutura foi então selada com uma fita de Teflon para evitar o vazamento dos gases formando a estrutura final da meia célula, de acordo com as referências $[88,89,90]$.

\subsubsection{Experimentos Eletroquímicos em Célula com Eletrólito Estagnante e em Fluxo em} Temperatura Ambiente.

Voltametria cíclica e cronoamperometria foram realizadas usando um Autolab PGSTAT 30 equipado com módulo analógico. Todos os experimentos foram realizados em eletrólito $0,5 \mathrm{~mol} \mathrm{~L}^{-1} \mathrm{H}_{2} \mathrm{SO}_{4}$ (célula com eletrólito estagnante) (Figura 12(a)) e eletrólito 2,0 $\mathrm{mol} \mathrm{L}^{-1} \mathrm{H}_{2} \mathrm{SO}_{4}$ (célula com eletrólito em fluxo) (Figura 12(b)), preparado de reagentes de alta pureza (Sigma-Aldrich) e água purificada em um sistema Milli-Q (Millipore) sob temperatura controlada de $25 \pm 0,1{ }^{\circ} \mathrm{C}$ usando um termostato Hakee-K20. Uma folha de platina platinizada, na forma de um anel, serviu como contra eletrodo e um eletrodo reversível de hidrogênio (Reversible Hydrogen Electrode - RHE), no mesmo eletrólito, foi usado como eletrodo de referência. A oxidação eletroquímica do etanol foi realizada utilizando um eletrodo poroso (célula com eletrólito estagnante) e um disco de carbono vítreo (célula com eletrólito em fluxo) no equipamento de DEMS (Figura 12d), em todas as condições usou-se uma solução $\mathrm{C}_{2} \mathrm{H}_{5} \mathrm{OH}$ 0,1 $\mathrm{mol} \mathrm{L}^{-1}$. Em ambas as condições (estagnante e fluxo) uma suspensão de eletrocatalisador com $2,0 \mathrm{mg} \mathrm{mL}^{-1}$ foi preparada 
usando um banho de ultrassom para dispersar o pó do eletrocatalisador [47]. Uma alíquota de $180 \mu \mathrm{L}$ da suspensão dispersada foi pipetada sobre o topo de um disco de carbono vítreo (célula de fluxo) ou sobre uma camada porosa de ouro, obtida por sputtering, em uma membrana de Teflon (célula estagnante), e secos em vácuo. Os produtos reacionais foram monitorados por DEMS on-line. A célula eletroquímica sob condições de fluxo contínuo apresentada na Figura 12(b), foi confeccionada em Kel-F, de acordo com instruções publicadas em trabalhos prévios [91]. O eletrodo de trabalho foi formado pelo depósito do eletrocatalisador sobre um disco de carbono vítreo, e posicionado no topo da célula, formando uma configuração do tipo "wall-jet". Nesta célula, após a ocorrência da reação na superfície do eletrocatalisador, os produtos reacionais são transportados por quatro tubos capilares até a interface com o espectrômetro (membrana porosa e hidrofóbica de Teflon), e as espécies voláteis ou gasosas se difundem pela membrana e são detectadas pelo espectrômetro. Para esta condição, utilizou-se um contra-eletrodo na entrada e outro na saída do eletrólito, para minimização de queda ôhmica, sendo o eletrodo de referência posicionado na saída do eletrólito, ver esquema na Figura 13. 
Figura 12 - Esquematização do sistema experimental: (a) célula eletroquímica com eletrólito estagnante; (b) célula eletroquímica de fluxo (Dual Thin Layer Flow Cell); (c) Ponta porosa de Teflon (Inlet tip) para detecção dos produtos a $245^{\circ} \mathrm{C}$; (d) Equipamento de DEMS para os experimentos eletroquímicos on-line. (1) Unidade eletrônica de controle conectada com um computador; (2) câmara com analisador quadrupolar; (3) pré-câmara de vácuo; (4-5) bombas turbomoleculares; (6) entrada para a célula eletroquímica.

(a)

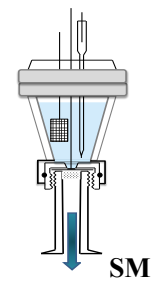

(b)

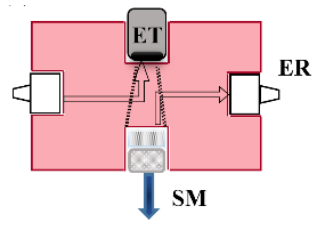

(c)

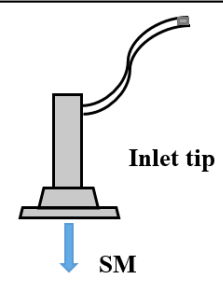

(d)
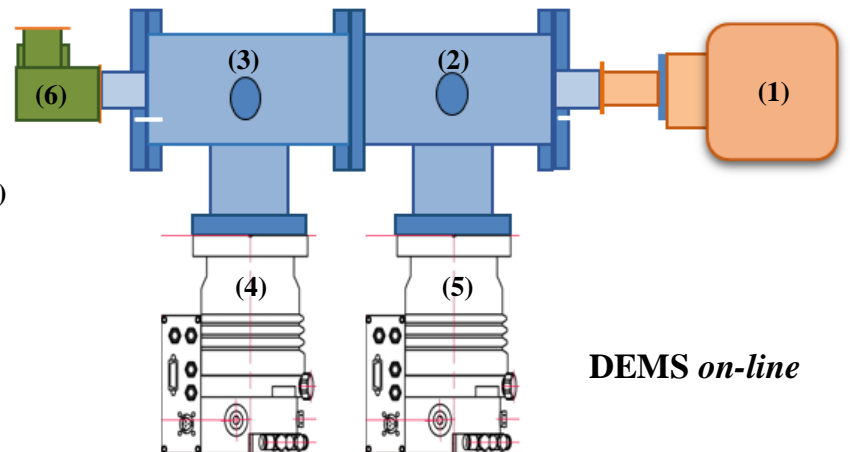

Fonte: Autoria própria

Figura 13 - Esquema do sistema usado para o estudo da reação de eletro-oxidação de etanol sob condições de fluxo contínuo em temperatura ambiente, com acoplamento no espectrômetro de massas.

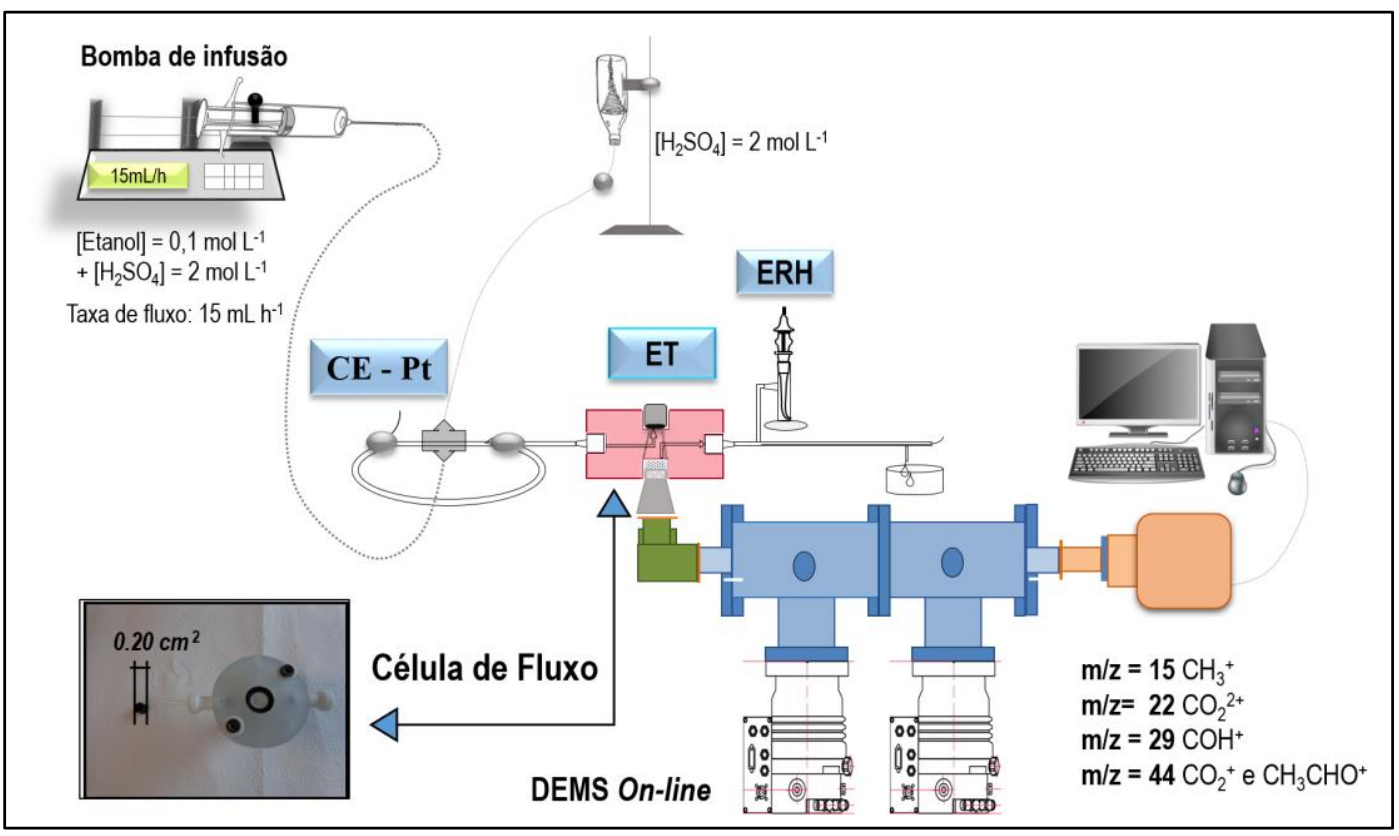

Fonte: Autoria própria 


\subsubsection{Experimentos Eletroquímicos em Eletrólito de Ácido Sólido a $245^{\circ} \mathrm{C}$}

As medidas eletroquímicas para a eletro-oxidação de etanol em meias células, operando com ácido sólido como eletrólito, foram realizadas por meio de curvas de polarização a $0,01 \mathrm{~V} \mathrm{~s}^{-1}$ e curvas cronoamperométricas. A célula foi mantida a $245^{\circ} \mathrm{C}$, sendo a configuração experimental mostrada na Figura 14. A célula foi colocada entre duas bases de aço inoxidável porosas e seladas com fita de Teflon para evitar vazamentos dos gases, e então inseridas entre dois suportes de aço que possuem as linhas de entrada e saída dos gases e conectadas ao AUTOLAB. Etanol 36\% em volume, foi bombeado para a célula usando uma bomba injetora (KDS-100 Infusion Pump) com taxa de fluxo de $7,2 \mathrm{~mL} \mathrm{~h}^{-1}$. Hidrogênio foi borbulhado em água mantida a $80^{\circ} \mathrm{C}$, e seguiu para o lado oposto do eletrodo de trabalho (contendo $\mathrm{Pt}$ ) que funcionou como contra-eletrodo e eletrodo de referência (Hydrogen Dynamic Electrode - HDE), não polarizável. Os produtos reacionais foram detectados por DEMS através de um sensor de ponta (inlet tip) (Figura 12c) conectado na saída do eletrodo de trabalho. 
Figura 14 - Esquema do sistema usado para o estudo da reação de eletro-oxidação de etanol sob condições de fluxo contínuo com eletrólito de ácido sólido, com acoplamento no espectrômetro de massas usando um sensor de ponta (inlet tip).

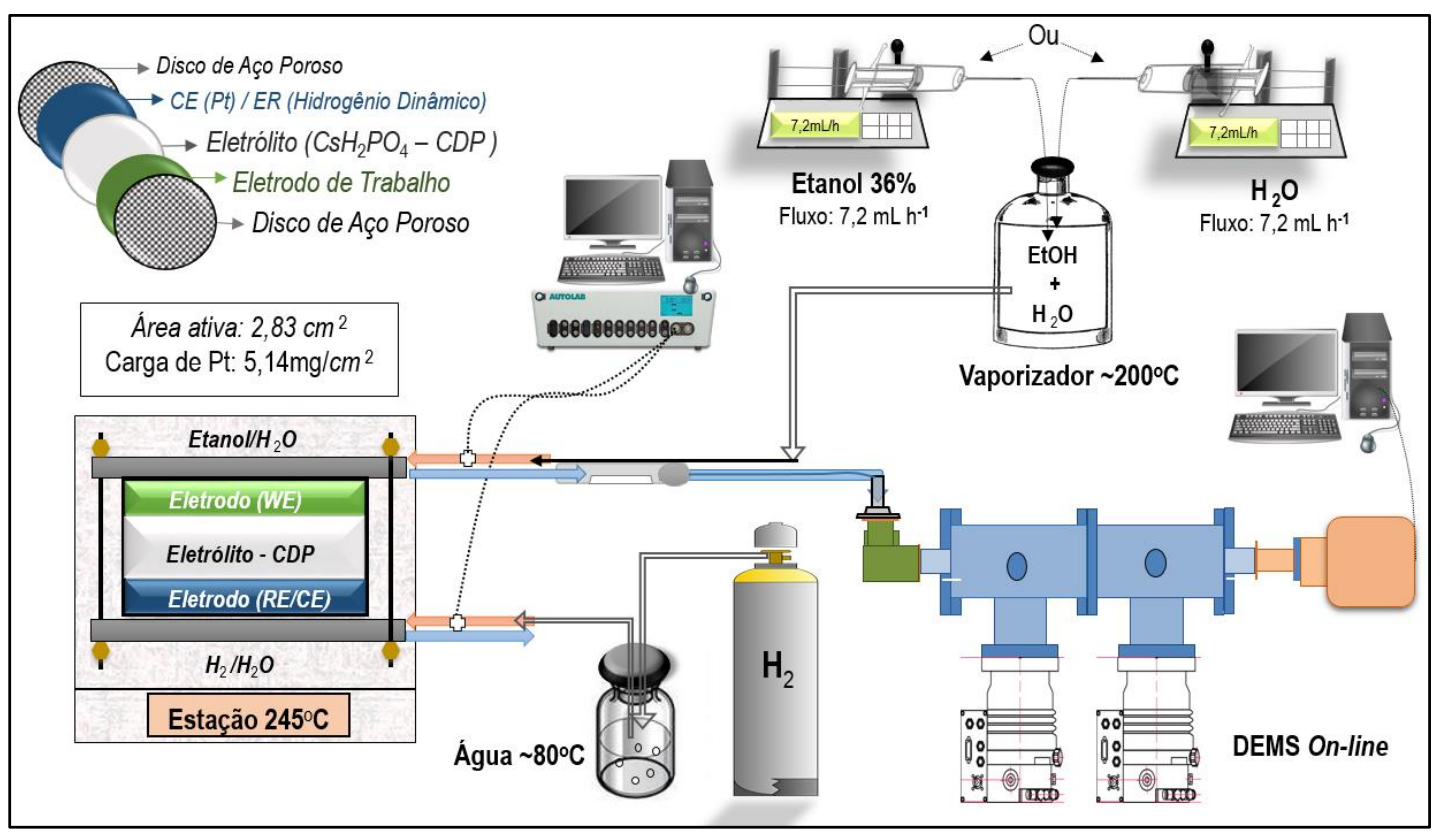

Fonte: Autoria própria

2.3.5 Determinação dos Produtos da Eletro-oxidação de Etanol por Espectrometria de Massas on-line

A saída do eletrodo de trabalho foi acoplada ao espectrômetro de massas (detalhes apresentados na seção anterior (ver Figuras 12-14)), para detecção dos produtos reacionais. Medidas de DEMS on-line foram realizadas com um espectrômetro de massas quadrupolar (Pfeiffer Vacuum QMA 200) usando uma configuração consistindo de duas câmaras de bombeamento, detalhes sobre esta técnica podem ser encontrados na seção 1.3.3. Tal técnica permite a detecção on-line dos produtos voláteis e gasosos das reações eletroquímicas durante a aplicação de uma varredura de potencial. As células eletroquímicas utilizadas neste trabalho foram construídas de acordo com os princípios de publicações prévias $[48,50,72,91]$. Nos experimentos realizados neste trabalho, os valores de corrente versus potencial foram gravados simultaneamente com os valores de 
intensidade de massa versus potencial, para valores selecionados de sinais iônicos $\mathrm{m} / \mathrm{z}$ (massa/carga). Os eletrodos foram ciclados no intervalo de potencial de 0,1 a 1,0 V (célula estagnante) e 0,1 a 0,8 V (célula de fluxo) para o material trimetálico e entre 0,1 a 1,2 V para $\mathrm{Pt} / \mathrm{C}$, em todas as condições a velocidade de varredura foi $0,01 \mathrm{~V} \mathrm{~s}^{-1}$.

Para as medidas de DEMS, os eletrodos de trabalho foram preparados na forma de um filme fino pipetando um total de $180 \mu \mathrm{L}$ de uma suspensão aquosa do eletrocatalisador $\left(2,0 \mathrm{mg}\right.$ em $1,0 \mathrm{~mL}$ de água $+100 \mu \mathrm{L}$ de Nafion ${ }^{\circledR}$ solução -5 wt.\%, Aldrich) [47] sobre uma camada de ouro (área de $1,13 \mathrm{~cm}^{2}$ e espessura de $50 \mathrm{~nm}$ ), obtida por pulverização (sputter deposition) sobre uma membrana de Teflon Gore-Tex ${ }^{\circledR}$ PTFE (diâmetro de poro de $0,02 \mu \mathrm{m}$ ) para a célula operando sob condições estagnantes e sobre um disco de carbono vítreo (área de $0,20 \mathrm{~cm}^{2}$ ) para a célula operando sob condições de fluxo contínuo.

Os produtos da reação de eletro-oxidação de etanol foram monitorados individualmente. Dióxido de carbono e acetaldeído foram seguidos pelos sinais iônicos de massa $m / z=22$ (sinal duplamente ionizado $\mathrm{CO}_{2}{ }^{++}, 2,8 \%$ do principal pico de $\mathrm{CO}_{2} \mathrm{~m} / \mathrm{z}$ $=44)$ e $m / z=29\left(\mathrm{COH}^{+}\right.$principal fragmento, $220 \%$ do pico de acetaldeído $\left.\mathrm{m} / \mathrm{z}=44\right)$, respectivamente. $\mathrm{O}$ sinal iônico $\mathrm{m} / \mathrm{z}=22$ foi monitorado ao invés do $\mathrm{m} / \mathrm{z}=44$ a fim de evitar interferências entre as correntes iônicas dos principais produtos reacionais da eletro-oxidação de etanol $\mathrm{CO}_{2}{ }^{+}$e $\mathrm{CH}_{3} \mathrm{CHO}^{+}$, onde ambos são $\mathrm{m} / z=44$, como usado em publicações prévias [51-53].

Análises quantitativas de medidas de DEMS para a condição em temperatura ambiente foram realizadas seguindo os procedimentos prévios [24], já descritos na seção 1.3.3. Enquanto as análises a $245^{\circ} \mathrm{C}$ foram feitas adaptando-se este mesmo método para o cálculo da constante de calibração, visto que a $245^{\circ} \mathrm{C}$ o CO não sofre adsorção sobre a superfície eletrocatalítica, a constante, $\mathrm{K}_{2}{ }^{*}$, foi determinada usando hidrogênio 
(fragmento iônico $m / z=2$ ). As eficiências médias de corrente para a completa eletrooxidação de etanol a $\mathrm{CO}_{2}$ por átomo de carbono foram calculadas removendo a contribuição para formação de $\mathrm{CO}_{2}$ em potential de circuito aberto e a carga faradaica associada ao consumo de $\mathrm{H}_{2}$ (eletro-oxidação de hidrogênio) quando o potential é aplicado, conforme mostrado na Figura 15. Desta forma, foi possível determinar os valores de eficiência de conversão a $\mathrm{CO}_{2}$ associados somente com a etapa eletroquímica (reação de eletro-oxidação de etanol).

Figura 15 - Representação do procedimento usado para o cálculo das eficiências de eletro-conversão de etanol a $\mathrm{CO}_{2}$ (rota eletroquímica).

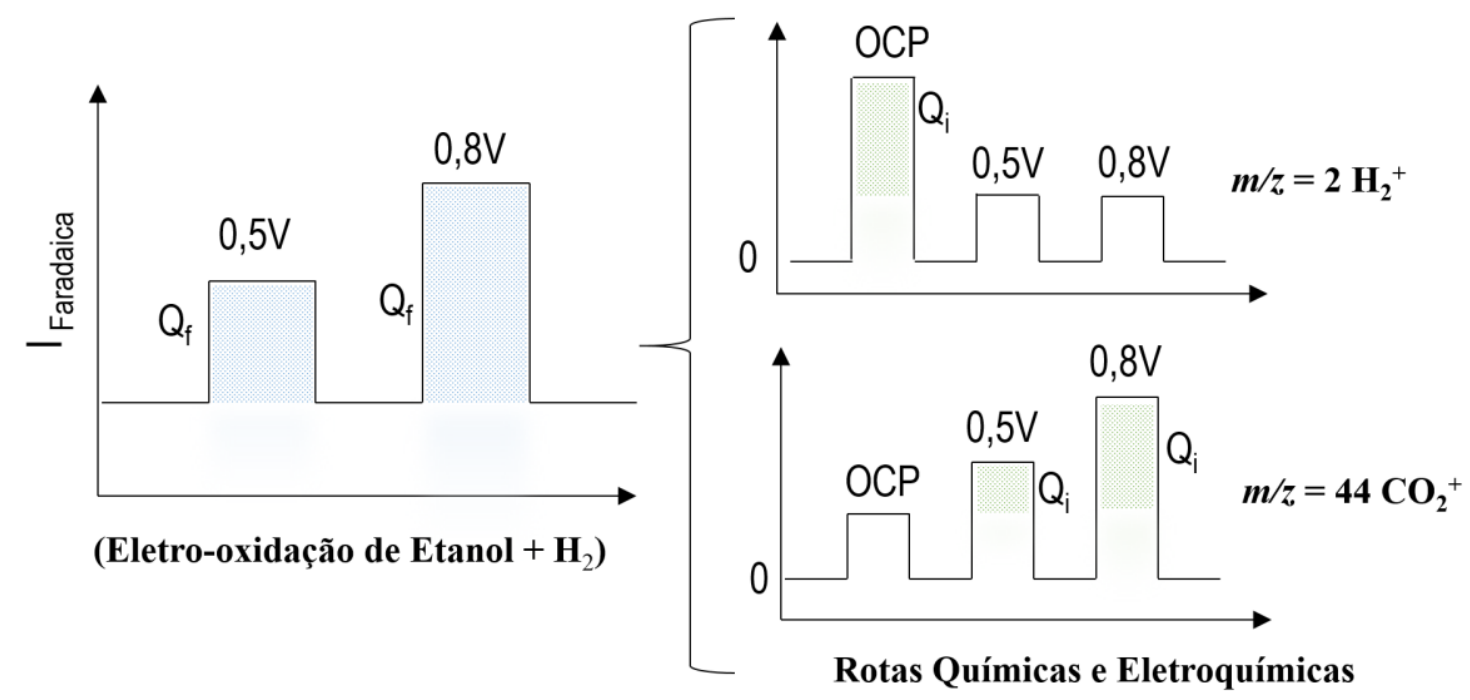

Fonte: Autoria própria 


\subsection{RESULTADOS E DISCUSSÃO}

\subsubsection{Caracterização das Nanopartículas}

A Figura 16 apresenta: (a) histograma de distribuição de partículas; (b) imagem de microscopia de transmissão e (c) resultados de difratometria de Raios X obtidos para o eletrocatalisador de $\mathrm{SnO}_{\mathrm{x}} \mathrm{RuO}_{\mathrm{x}}-\mathrm{Pt} / \mathrm{C}$. Pode-se observar os principais picos característicos da estrutura cristalina cúbica de face centrada da platina (Figura 16(c), evidenciada pela difração dos planos (111), (200), (220), (311) e (222). Os picos de difração para este material apresentam um suave deslocamento para maiores ângulos em relação ao da Pt/C. No entanto, este deslocamento não foi tão pronunciado, conduzindo a um parâmetro de rede próximo à $\mathrm{Pt} / \mathrm{C}$ (Tabela 3). Para o eletrocatalisador $\mathrm{SnO}_{\mathrm{x}} \mathrm{RuO}_{\mathrm{x}}$ $\mathrm{Pt} / \mathrm{C}$, é possível notar, ainda, picos intensos, refletindo em maiores valores de tamanho médio de cristalito. Estes fatos indicam baixo grau de formação de liga ou baixa inserção dos átomos de Ru e Sn na estrutura da Pt. Neste caso, é provável que a estrutura do eletrocatalisador seja formada por átomos de Pt em íntimo contato com óxidos de Sn e/ou Ru localizados na superfície.

Analisando-se a Figura 16(c), é possível notar, também, picos de difração bastante estreitos para o trimetálico. O que segue as estimativas obtidas usando a equação de Sherrer para os tamanhos médios de cristalito, que resultaram em cristalitos maiores para o material trimetálico quando comparado aquele para $\mathrm{Pt} / \mathrm{C}$, conforme pode ser observado na Tabela 3. Nesta Tabela, é apresentada, também, a composição atômica do eletrocatalisador trimetálico, determinada por medidas de X-EDS. Os resultados mostram que a razão atômica foi próxima de 1:1:4 Sn:Ru:Pt, sendo este valor maior do que o nominal calculado 1:1:3 para este eletrocatalisador (Sn:Ru:Pt). De acordo com o 
histograma de distribuição e a imagem de TEM (Figura 16(a-b)), o tamanho médio de partícula para o trimetálico foi 3,8 nm. No entanto, esse catalisador não é homogêneo, apresentando aglomerados largos, o que explica o alto valor de tamanho de cristalito obtido a partir das medidas de XRD (alto peso para partículas maiores).

Figura 16 - (a) Histograma de distribuição de partículas; (b) Imagem de TEM e (c) Padrões de difração de Raios $X$ obtidos para o eletrocatalisador $\mathrm{SnO}_{\mathrm{x}} \mathrm{RuO}_{\mathrm{x}}-\mathrm{Pt} / \mathrm{C}$ como preparado.

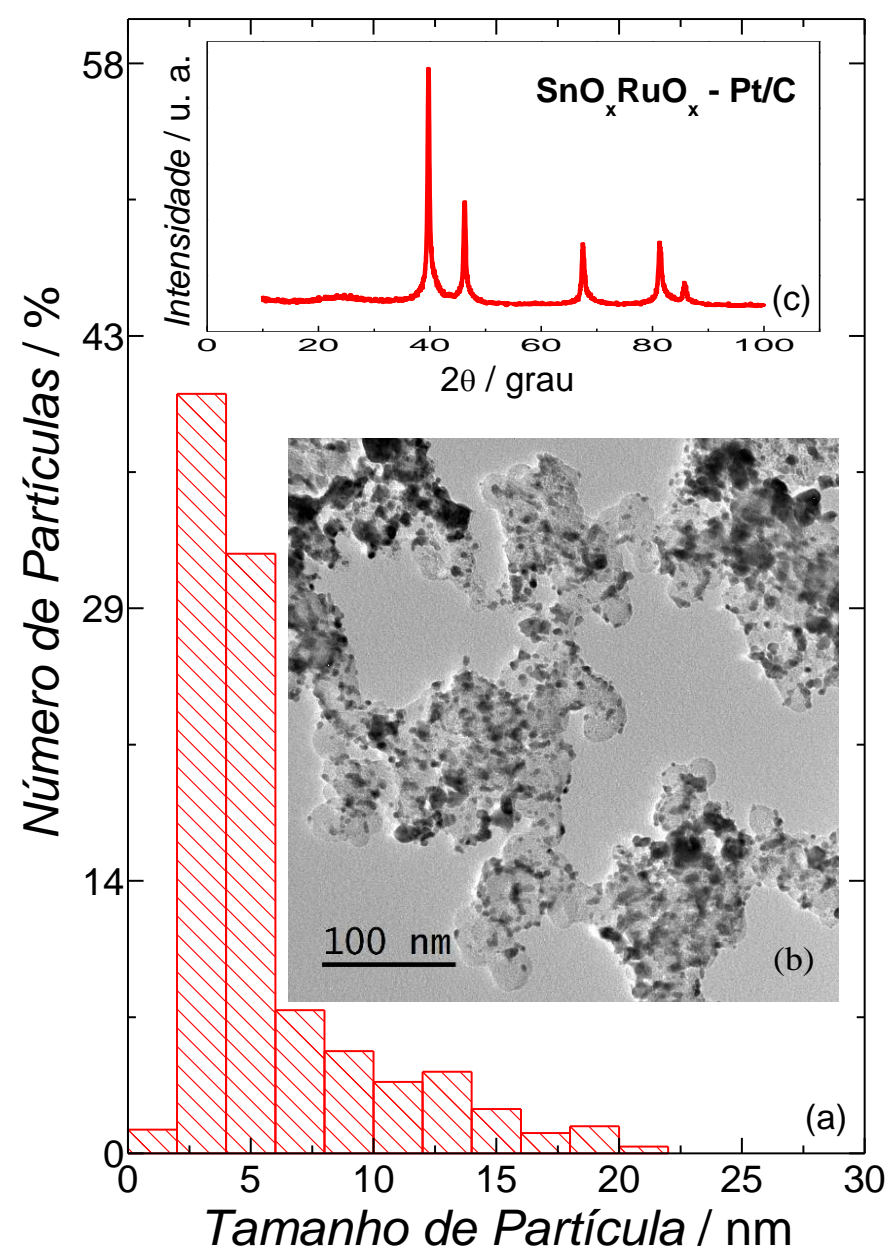

Fonte: Autoria própria 
Tabela 3 - Composição atômica média, tamanho médio de cristalito e partícula, e parâmetro de rede obtidos por X-EDS, DRX e TEM para o trimetálico investigado comparado com Pt/C E-TEK $20 \%$.

\begin{tabular}{|c|c|c|c|c|c|}
\hline \multirow[b]{2}{*}{ Amostra } & \multicolumn{2}{|r|}{ X-EDS } & TEM & \multicolumn{2}{|c|}{ XRD } \\
\hline & $\begin{array}{l}\text { Composição } \\
\text { atômica } \\
\text { - nominal } \\
\text { (M:M:Pt) }\end{array}$ & $\begin{array}{c}\text { Composição atômica } \\
\text { percentual - } \\
\text { como preparado } \\
(\mathrm{M}(\%): \mathrm{M}(\%): \mathrm{Pt}(\%))\end{array}$ & $\begin{array}{l}\text { Tamanho } \\
\text { médio de } \\
\text { partícula } \\
\text { / nm }\end{array}$ & $\begin{array}{l}\text { Tamanho } \\
\text { médio de } \\
\text { cristalito } \\
\text { / nm }\end{array}$ & $\begin{array}{c}\text { Parâmetro } \\
\text { de rede / } \\
\text { nm }\end{array}$ \\
\hline $\mathrm{SnO}_{\mathrm{x}} \mathrm{RuO}_{\mathrm{x}}-\mathrm{Pt} / \mathrm{C}$ & $1: 1: 3$ & 16: 17: $67(1: 1: 4)$ & 3,8 & 21,2 & 0,3927 \\
\hline $\mathrm{Pt} / \mathrm{C}$ & - & - & 2,5 & 2,8 & 0,3923 \\
\hline
\end{tabular}

Fonte: Autoria própria.

2.4.2 Experimentos de DEMS para a Eletro-oxidação de Etanol em Célula com Eletrólito Estagnante.

A Figura 17(a) mostra as correntes de oxidação de CO adsorvido (stripping de CO) e os insets (b) e (c) mostram os sinais iônicos dos fragmentos de massa $\mathrm{m} / \mathrm{z}=22 \mathrm{e}$ $m / z=44$, respectivamente, ambos correspondendo à formação de $\mathrm{CO}_{2}$. O eletrocatalisador $\mathrm{SnO}_{\mathrm{x}} \mathrm{RuO}_{\mathrm{x}}-\mathrm{Pt} / \mathrm{C}$ apresentou mais baixo potencial de início de oxidação quando comparado com o potencial para $\mathrm{Pt} / \mathrm{C}$. Este fato é uma consequência da oxidação de CO ser facilitada sobre materiais contendo $\mathrm{Ru}$ ou Sn. Isto pode ser explicado pelo mecanismo bifuncional, em que átomos de $\mathrm{Ru}$ ou $\mathrm{Sn}$ providenciam espécies oxigenadas para o acoplamento $\mathrm{CO}-\mathrm{O}$, como proposto anteriormente [32]. Adicionalmente, $\mathrm{SnO}_{\mathrm{x}} \mathrm{RuO}_{\mathrm{x}}-\mathrm{Pt} / \mathrm{C}$ apresentou maior corrente iônica para formação de $\mathrm{CO}_{2}$, como pode ser observado na Figura 17(b, c), o que pode estar associado a um maior grau de recobrimento por $\mathrm{CO}$ na superfície do material ternário, induzido pela presença dos átomos de $\mathrm{Ru}$ e $\mathrm{Sn}$ em sua superfície, devido à uma diminuição da repulsão lateral entre as moléculas de CO adsorvidas. 
Logo, a combinação entre $\mathrm{Pt}, \mathrm{Sn}$ e $\mathrm{Ru}$ intensifica a oxidação de $\mathrm{CO}$ em mais baixos potenciais, favorecendo maiores correntes iônicas e faradaicas. Outra característica importante está associada ao pico de corrente faradaica (e, por consequência, das correntes iônicas) mais largo para o material trimetálico em relação à Pt/C. Este fato pode ser atribuído à presença de cristalitos com diferentes tamanhos e, portanto, diferentes forças de adsorção de $\mathrm{CO}$, o que resulta em diferentes potenciais para a eletro-oxidação.

Figura 17 - (a) Perfis voltamétricos e correntes iônicas para (b) $m / z=22\left(\mathrm{CO}_{2}, \mathrm{CO}_{2}{ }^{2+}\right)$ e (c) $m / z=44\left(\mathrm{CO}_{2}, \mathrm{CO}_{2}{ }^{+}\right)$obtidas durante experimentos de DEMS (stripping de $\mathrm{CO}$ ) sobre $\mathrm{SnO}_{x} \mathrm{RuO}_{\mathrm{x}}-\mathrm{Pt} / \mathrm{C}$ e Pt/C E-TEK em $\mathrm{H}_{2} \mathrm{SO}_{4} 0,5 \mathrm{~mol} \mathrm{~L}^{-1}$ a $25^{\circ} \mathrm{C}$. $\mathrm{O}$ potencial foi mantido a $0,1 \mathrm{~V}$ durante 30 min em solução saturada com CO depois a solução foi saturada com argônio durante 30 minutos. Velocidade de varredura de $0,01 \mathrm{~V} \mathrm{~s}^{-1}$.

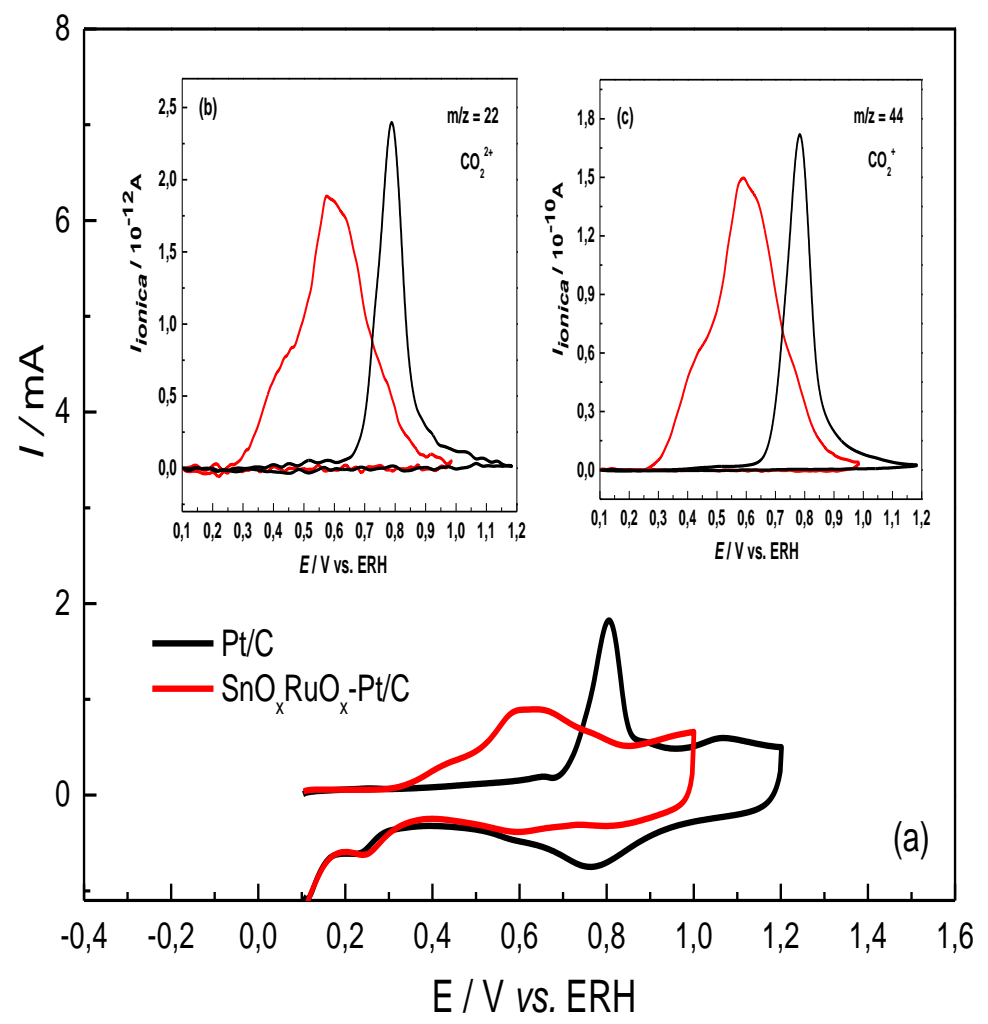

Fonte: Autoria própria 
A Figura 18(a) apresenta os voltamogramas cíclicos (CVs) para a eletrooxidação de etanol catalisada por $\mathrm{SnO}_{\mathrm{x}} \mathrm{RuO}_{\mathrm{x}}-\mathrm{Pt} / \mathrm{C}$ e $\mathrm{Pt} / \mathrm{C}$, obtidos utilizando-se uma célula com eletrólito estagnante em $0,1 \mathrm{~mol} \mathrm{~L}^{-1}$ etanol + 0,5 $\mathrm{mol} \mathrm{L}^{-1} \mathrm{H}_{2} \mathrm{SO}_{4}$. Enquanto a Figura 18(b-d) mostra as correspondentes correntes iônicas para dióxido de carbono e acetaldeído. Os fragmentos iônicos monitorados foram $\mathrm{m} / \mathrm{z}=22$, que corresponde ao dióxido de carbono duplamente ionizado $\left[\mathrm{CO}_{2}{ }^{++}\right]$e o acetaldeído foi seguido monitorando o sinal $m / z=29$, que corresponde ao fragmento $\left[\mathrm{CHO}^{+}\right.$. O sinal iônico em $\mathrm{m} / z=44$ também foi monitorado, e é associado à formação de $\mathrm{CO}_{2},\left[\mathrm{CO}_{2}^{+}\right]$e acetaldeído, $\left[\mathrm{CH}_{3} \mathrm{CHO}^{+}\right)[60,61]$. A análise das curvas da Figura 18, mostra que o potencial de onset para a eletro-oxidação de etanol sobre $\mathrm{SnO}_{\mathrm{x}} \mathrm{RuO}_{\mathrm{x}}-\mathrm{Pt} / \mathrm{C}$ é mais baixo do que aquele observado para Pt/C. No entanto, este menor potencial de onset não está relacionado somente com a formação de dióxido de carbono, mas, também, com a formação de acetaldeído. Além disso, a maior corrente faradaica obtida para o eletrocatalisador trimetálico é associada com os maiores valores de correntes iônicas obtidas para $\mathrm{CO}_{2} \mathrm{e}$ acetaldeído. $\mathrm{O}$ catalisador trimetálico $\mathrm{SnO}_{\mathrm{x}} \mathrm{RuO} \mathrm{O}_{\mathrm{x}}-\mathrm{Pt} / \mathrm{C}$ apresentou eficiência para conversão de $\mathrm{CO}_{2}$ bastante próxima ao valor calculado para Pt/C E-TEK 20\% (Tabela 4). O menor potencial de onset observado para $\mathrm{SnO}_{\mathrm{x}} \mathrm{RuO}_{\mathrm{x}}-\mathrm{Pt} / \mathrm{C}$ pode ser associado com o mecanismo bifuncional (Figura 19), visto que estanho e rutênio favorecem a ativação de moléculas de água em potenciais mais baixos do que platina, produzindo espécies oxigenadas que oxidam os intermediários adsorvidos sobre a superfície da Pt (sítios ativos para quebra da ligação C-C) e conduzindo, portanto, a oxidação destas espécies em menores valores de potenciais. 
Figura 18 - (a) Perfis voltamétricos e correntes iônicas obtidas em experimentos de DEMS durante voltametria cíclica para a eletro-oxidação de etanol catalisada por $\mathrm{SnO}_{\mathrm{x}} \mathrm{RuO}_{\mathrm{x}}-\mathrm{Pt} / \mathrm{C}$ e Pt/C E-TEK (b) $\mathrm{m} / z=22\left(\mathrm{CO}_{2}{ }^{2+}\right)$; (c) $m / z=29$ (acetaldeído, $\mathrm{CHO}^{+}$), e (d) $\mathrm{m} / z=44\left(\mathrm{CO}_{2}, \mathrm{CO}_{2}{ }^{+}\right.$e acetaldeído, $\left.\mathrm{CH}_{3} \mathrm{CHO}^{+}\right)$, em $0,1 \mathrm{~mol} \mathrm{~L}^{-1}$ de etanol e $\mathrm{H}_{2} \mathrm{SO}_{4} 0,5 \mathrm{~mol} \mathrm{~L}^{-1}$ a $25^{\circ} \mathrm{C}$. Velocidade de varredura de $0,01 \mathrm{~V} \mathrm{~s}^{-1}$.

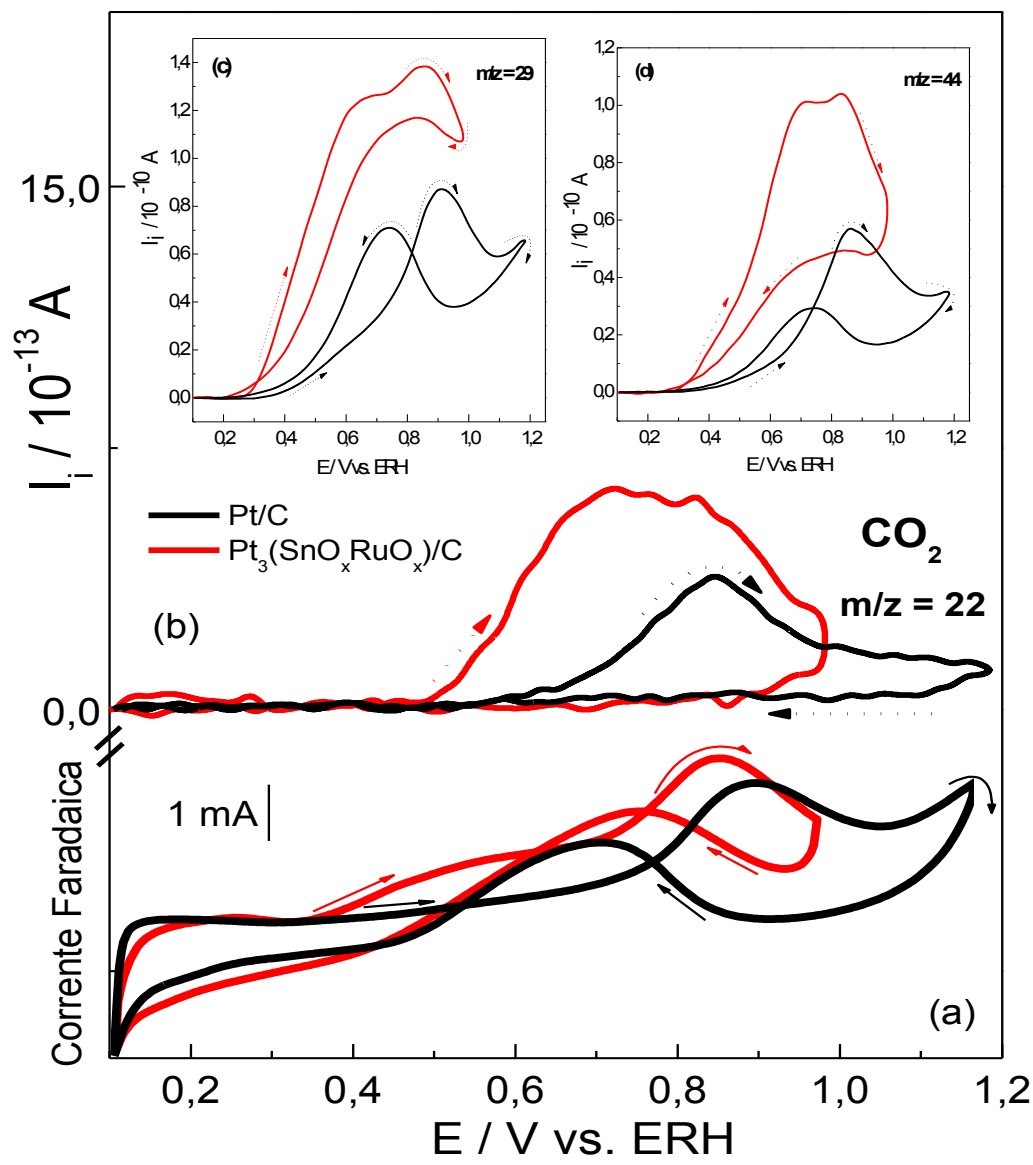

Fonte: Autoria própria

Tabela 4 - Eficiências médias de corrente (Aq) para $\mathrm{CO}_{2}$ durante a eletro-oxidação de etanol eletrocatalisada por $\mathrm{SnO}_{x} \mathrm{RuO}_{\mathrm{x}}-\mathrm{Pt} / \mathrm{C}$ e Pt/C E-TEK $20 \%$, obtidas em $0,1 \mathrm{~mol} \mathrm{~L}^{-1}$ etanol $+0,5 \mathrm{~mol} \mathrm{~L}^{-1} \mathrm{H}_{2} \mathrm{SO}_{4}$ em temperatura ambiente, integrandose um ciclo voltamétrico completo.

\begin{tabular}{ccc}
\hline Eletrocatalisador & $\mathbf{K}^{*}{ }_{22}$ & $\begin{array}{c}\mathbf{A}_{\mathbf{i}}\left(\mathbf{C O}_{2}\right) / \mathbf{C V} \text { etanol } \mathbf{0 . 1} \\
\mathbf{m o l ~ L}^{-\mathbf{1}}\end{array}$ \\
\hline $\mathrm{SnO}_{\mathrm{x}} \mathrm{RuO}_{\mathrm{x}}-\mathrm{Pt} / \mathrm{C}$ & $6,28.10^{-9}$ & $15,60 \%$ \\
$\mathrm{Pt} / \mathrm{C} \mathrm{E}-\mathrm{TEK}$ & $3,16.10^{-9}$ & $15,20 \%$ \\
\hline
\end{tabular}


Figura 19- Ilustração do mecanismo bifuncional seguido pelo eletrocatalisador $\mathrm{SnO}_{\mathrm{x}} \mathrm{RuO}_{\mathrm{x}}-\mathrm{Pt} / \mathrm{C}$ para a reação de eletro-oxidação de etanol.

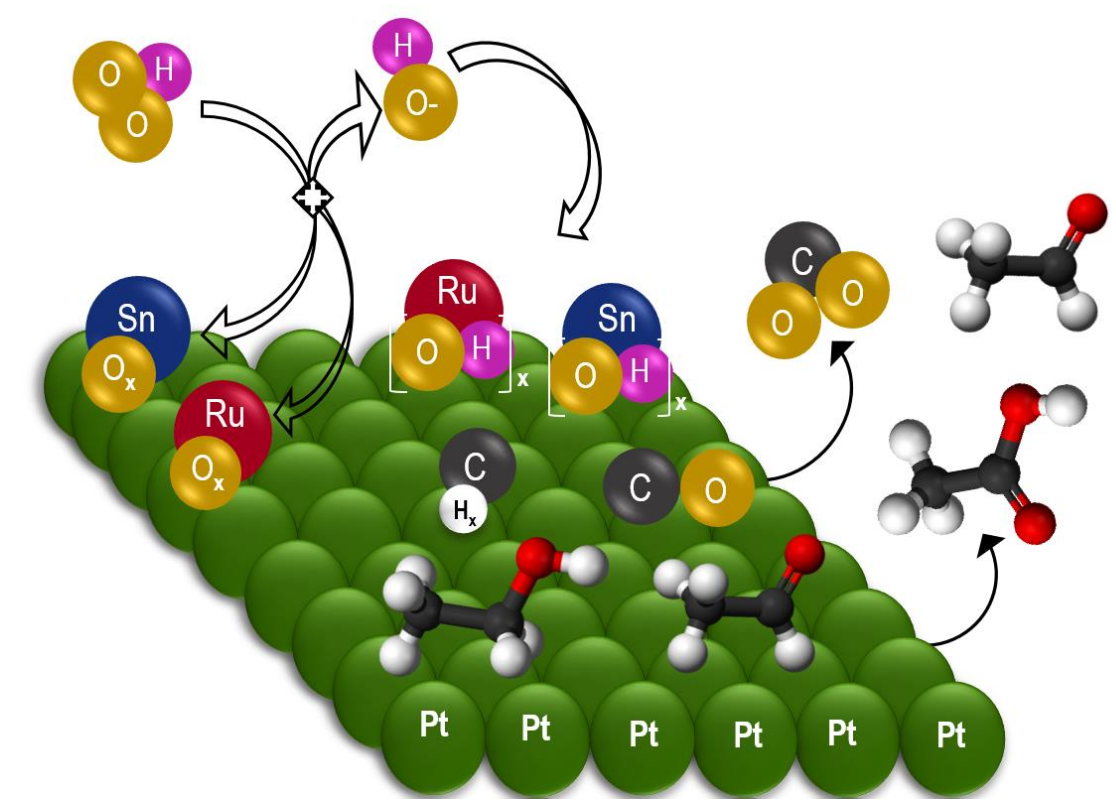

Fonte: Autoria própria.

A Figura 20(a) apresenta as correntes faradaicas e sinais iônicos 20(b) $\mathrm{m} / \mathrm{z}=22$ (insets (c) $m / z=29$ e (d) 44) em DEMS para a oxidação de etanol catalisada por $\mathrm{SnO}_{\mathrm{x}} \mathrm{RuO}_{\mathrm{x}}-\mathrm{Pt} / \mathrm{C}$ e Pt/C, obtidas durante medidas potenciostáticas. É possível observar uma tendência similar àquela obtida nas medidas potenciodinâmicas já apresentadas (Figura 18), onde o material trimetálico mostrou maiores valores de corrente a 0,5 V, 0,6 $\mathrm{V}$ e $0,8 \mathrm{~V}$ para todos os sinais iônicos monitorados por DEMS neste experimento $(\mathrm{m} / \mathrm{z}=$ 22, 29 e 44). Como pode ser observado, a taxa reacional global sobre este eletrocatalisador trimetálico é aumentada em relação à platina pura, mas a relação entre as vias de formação de acetaldeído e $\mathrm{CO}_{2}$ não é alterada (o aumento da corrente faradaica é seguido por um aumento proporcional das correntes iônicas). Para todos os casos, uma redução das correntes (faradaicas e iônicas) pode ser observada em função do tempo. Isto pode ser associado ao envenenamento da superfície eletrocatalítica por espécies, tais como $\mathrm{CO}$ e $\mathrm{CH}_{\mathrm{x}}$ durante o curso da reação de eletro-oxidação de etanol, como será mostrado a seguir. 
Figura 20 - (a) Curvas cronoamperométricas e correntes iônicas obtidas em experimentos de DEMS para a eletro-oxidação de etanol catalisada por $\mathrm{SnO}_{\mathrm{x}} \mathrm{RuO}_{\mathrm{x}}-\mathrm{Pt} / \mathrm{C}$ e $\mathrm{Pt} / \mathrm{C}$ E-TEK, (b) $\mathrm{m} / \mathrm{z}=22\left(\mathrm{CO}_{2}{ }^{++}\right)$, (c) $\mathrm{m} / \mathrm{z}=29$ (acetaldeído, $\mathrm{CHO}^{+}$) e (d) $\mathrm{m} / \mathrm{z}$ $=44\left(\mathrm{CO}_{2}, \mathrm{CO}_{2}{ }^{+}\right.$e acetaldeído, $\left.\mathrm{CH}_{3} \mathrm{CHO}^{+}\right)$em $0,1 \mathrm{~mol} \mathrm{~L}^{-1}$ etanol $+0,5 \mathrm{~mol}$ $\mathrm{L}^{-1} \mathrm{H}_{2} \mathrm{SO}_{4}$ a $25^{\circ} \mathrm{C}$. As curvas cronoamperométricas foram realizadas através de saltos de potenciais, sendo as correntes registradas a cada $10 \mathrm{~min}$.

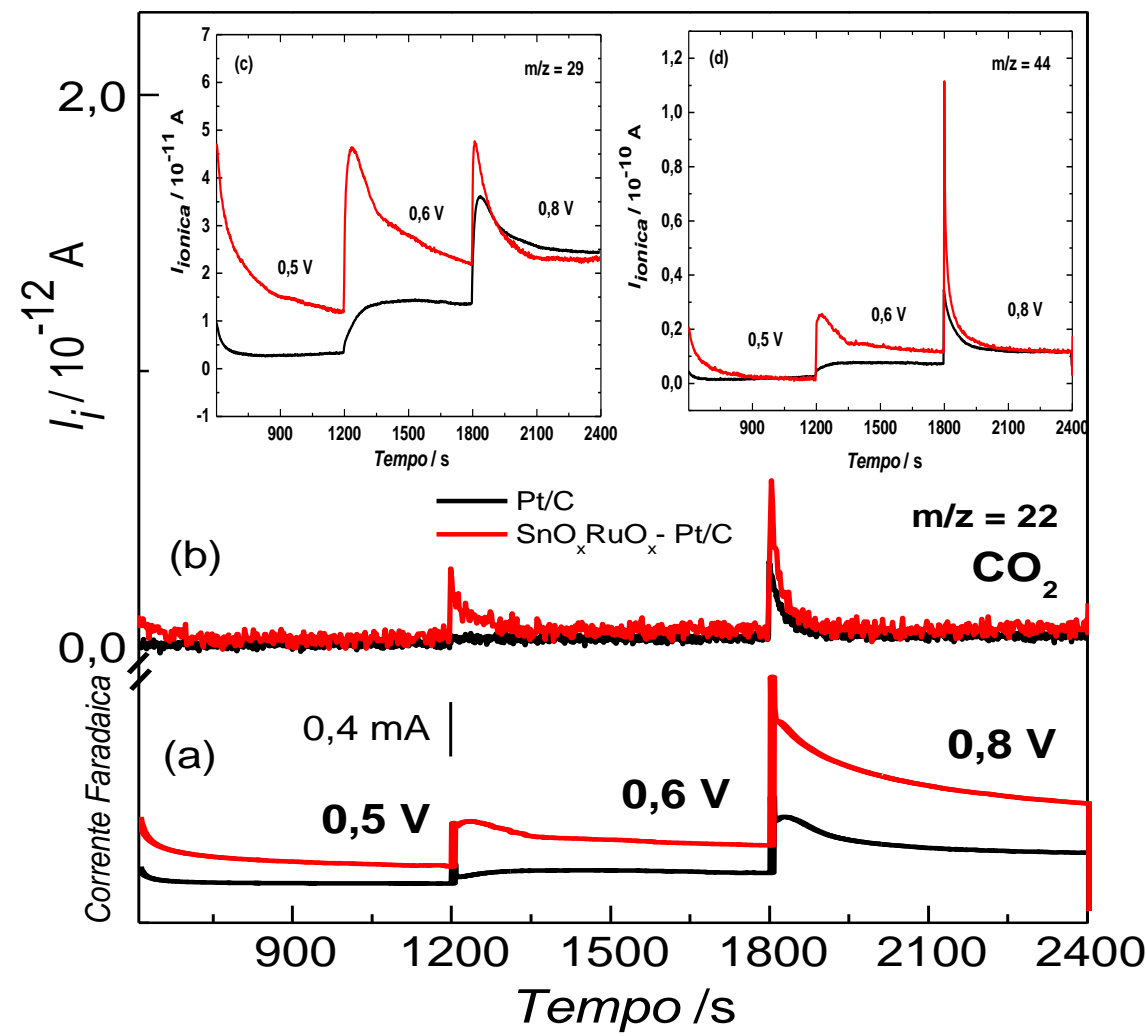

Fonte: Autoria própria.

2.4.3 Experimentos de DEMS para a Eletro-oxidação de Etanol em Célula com Eletrólito em Fluxo.

Nesta seção, a reação de eletro-oxidação de etanol sobre $\mathrm{SnO}_{x} \mathrm{RuO}_{\mathrm{x}}-\mathrm{Pt} / \mathrm{C}$ foi investigada em célula sob condições de fluxo contínuo. Neste sistema, a reação pode ser investigada em condições controladas por transporte de massa, evitando-se problemas associados com a falta de reagente sobre a superfície do eletrodo e múltiplos passos de re-adsorção de intermediários reacionais [91]. A Figura 21(a) apresenta o primeiro e o décimo voltamograma para a oxidação de etanol sobre $\mathrm{SnO}_{\mathrm{x}} \mathrm{RuO}_{\mathrm{x}}-\mathrm{Pt} / \mathrm{C}$, enquanto a 
Figura 21(b) apresenta as correntes iônicas $(m / z=15,22,29$ e 44) associadas aos produtos formados. As correntes faradaicas e iônicas foram monitoradas sem interrupção, sendo a rampa de potencial versus tempo apresentada como inset da Figura 21(b). Como pode ser observado, após 10 ciclos, a corrente faradaica sofre ligeira redução, sendo tal resultado acompanhado pela redução gradativa das intensidades das correntes iônicas. Assim, experimentos foram realizados com o objetivo de entender a origem ou o motivo da degradação das intensidades dos sinais de corrente faradaica e iônica durante a eletrooxidação de etanol.

Deste modo, as etapas para este procedimento envolveram a realização de stripping de adsorbatos de etanol, que consistiu na realização de voltametrias cíclicas consecutivas, após a troca da solução contendo eletrólito 2 mol L-1 $\mathrm{H}_{2} \mathrm{SO}_{4}+$ etanol 0,1mol $\mathrm{L}^{-1}$ por eletrólito puro, em circuito aberto $(\sim 0,3 \mathrm{~V})$. Isto foi seguido por experimentos de voltametria cíclica, sendo registrados os mesmos fragmentos iônicos quando na presença de etanol. A Figura 22(a) apresenta as correntes faradaicas e a Figura 22(b) mostra as correntes para os fragmentos iônicos detectados após ciclagem em eletrólito puro, com a rampa de potencial versus o tempo sendo mostrado como inset. Pode-se observar a formação de metano $(m / z=15)$ (curva azul), quando o potencial se inicia no valor de circuito aberto para $0,1 \mathrm{~V}$, e de dióxido de carbono $\left(\mathrm{m} / \mathrm{z}=44\left(\mathrm{CO}_{2}{ }^{+}\right)\right)$(curva verde), na varredura positiva, sendo suas intensidades de correntes iônicas da mesma ordem de magnitude. Por outro lado, nenhum sinal iônico para espécies com dois átomos de carbono (C-C) foi detectado, como, por exemplo, acetaldeído (ausência do sinal iônico $m / z=29)$. O sinal iônico referente à formação de metano é visível de forma mais pronunciada somente nos ciclos iniciais, enquanto, o sinal iônico referente à formação de $\mathrm{CO}_{2}, m / z=44$ é visível em todos os ciclos, mas com redução significativa ao longo da ciclagem. 
Estes resultados mostram que durante a eletro-oxidação de etanol, espécies contendo um átomo de carbono, tais como $\mathrm{CO}$ e $\mathrm{CH}_{\mathrm{x}}$, adsorvem fortemente sobre a superfície do eletrodo, causando o envenenamento do eletrocatalisador e reduzindo sua atividade para esta reação. A ausência de sinais relacionados com espécies com dois átomos de carbono, como o acetaldeído, por sua vez, mostra também que não há resíduos ou intermediários adsorvidos com a ligação carbono-carbono intacta. Além disso, o catalisador trimetálico $\mathrm{SnO}_{\mathrm{x}} \mathrm{RuO}_{\mathrm{x}}-\mathrm{Pt} / \mathrm{C}$ mostrou melhor desempenho para oxidar estas espécies em mais baixos e altos potenciais.

Figura 21 - (a) Perfis voltamétricos e (b) correntes iônicas obtidas em experimentos de DEMS durante a eletro-oxidação de etanol catalisada por $\mathrm{SnO}_{\mathrm{x}} \mathrm{RuO}_{\mathrm{x}}-\mathrm{Pt} / \mathrm{C}$ em $0,1 \mathrm{~mol} \mathrm{~L}^{-1}$ etanol $+2 \mathrm{~mol} \mathrm{~L}^{-1} \mathrm{H}_{2} \mathrm{SO}_{4}$ a $25^{\circ} \mathrm{C}$. Velocidade de varredura de $0,01 \mathrm{~V} \mathrm{~s}^{-1}$. A rampa do potencial em função do tempo é mostrada em inset em (b).

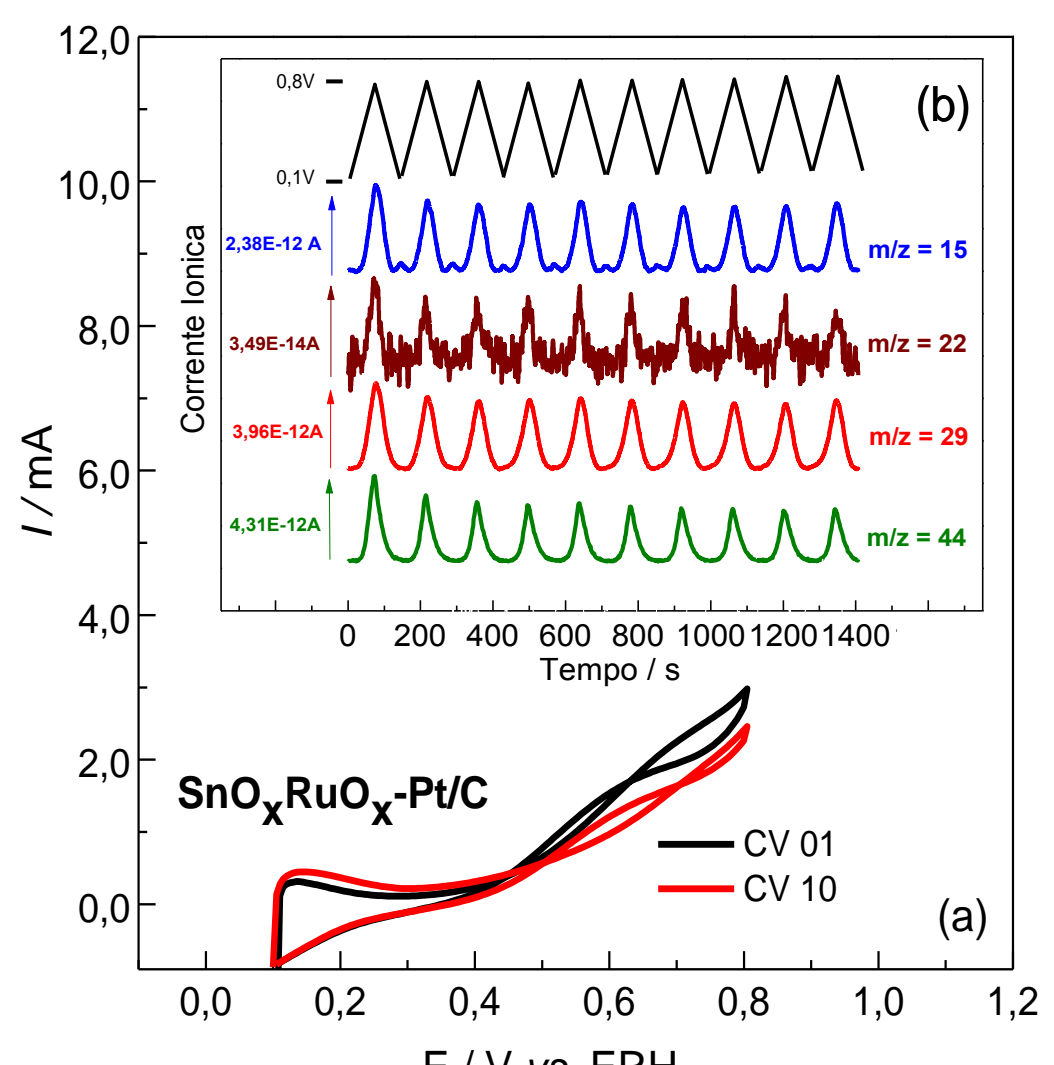

Fonte: Autoria própria

$\mathrm{E} / \mathrm{V}$ vs. ERH 
Figura 22 - (a) Perfis voltamétricos e (b) correntes iônicas $\mathrm{m} / \mathrm{z}=15$ (metano, $\mathrm{CH}_{4}{ }^{+}$) e $\mathrm{m} / \mathrm{z}$ $=44\left(\mathrm{CO}_{2}, \mathrm{CO}_{2}{ }^{+}\right)$obtidas em experimentos de DEMS durante CVs em eletrólito $\left(2 \mathrm{~mol} \mathrm{~L}^{-1} \mathrm{H}_{2} \mathrm{SO}_{4}\right)$ catalisada por $\mathrm{SnO}_{\mathrm{x}} \mathrm{RuO}_{\mathrm{x}}-\mathrm{Pt} / \mathrm{C}$ após eletrooxidação de etanol a $25^{\circ} \mathrm{C}$. Velocidade de varredura de $0,01 \mathrm{~V} \mathrm{~s}^{-1}$. A rampa do potencial em função do tempo é mostrada como inset.

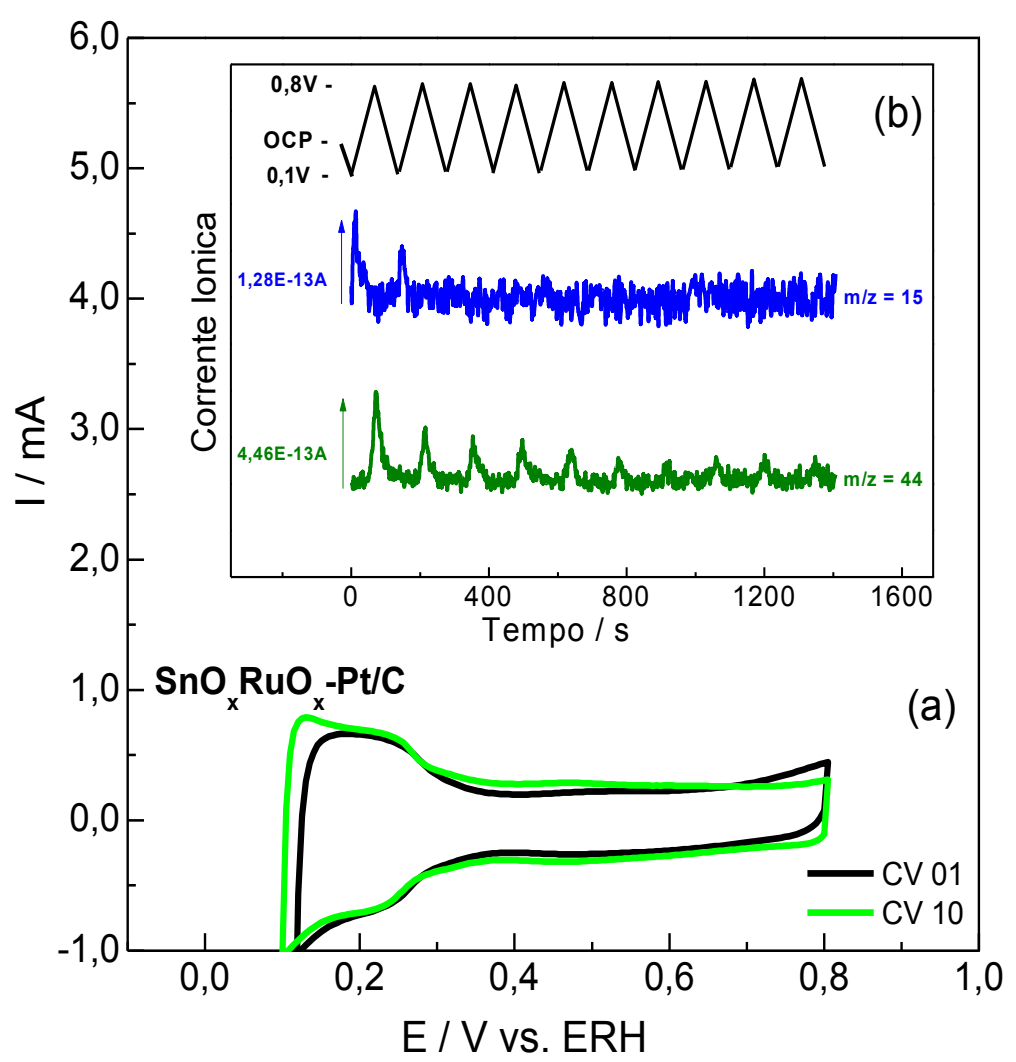

Fonte: Autoria própria.

Os experimentos conduzidos no laboratório mostraram que quanto maior o potencial excursionado na ciclagem, menor o número de ciclos necessários para que o sinal de $\mathrm{CO}_{2}$ diminuísse para zero (indicando total remoção do intermediário adsorvido que forma o $\mathrm{CO}_{2}$ ) (ver Figura 23). Além do que, o retorno do eletrólito contendo etanol após a retirada de grande parte das espécies adsorvidas sobre os sítios ativos mostra um aumento na intensidade da corrente faradaica, conforme pode ser observado na Figura 24(a). Apesar do menor intervalo de potencial ( $0,1 \mathrm{~V}$ a $0,8 \mathrm{~V})$ usado para a ciclagem em eletrólito puro é evidente o aumento nas correntes faradaica e iônicas (Figura 24b) indicando que a redução observada nas intensidades das correntes não estam associadas com a perda de catalisador, mas sim com o envenenamento da superfície eletrocatalítica. 
Figura 23 - Correntes iônicas $\mathrm{m} / \mathrm{z}=15\left(\right.$ metano, $\left.\mathrm{CH}_{4}{ }^{+}\right), \mathrm{m} / \mathrm{z}=22\left(\mathrm{CO}_{2}, \mathrm{CO}_{2}{ }^{++}\right), \mathrm{m} / \mathrm{z}=$ 29 (acetaldeído, $\left.\mathrm{CHO}^{+}\right)$e $\mathrm{m} / \mathrm{z}=44\left(\mathrm{CO}_{2}, \mathrm{CO}_{2}{ }^{+}\right)$obtidas em experimentos de DEMS durante CVs em eletrólito $\left(2 \mathrm{~mol} \mathrm{~L}^{-1} \mathrm{H}_{2} \mathrm{SO}_{4}\right)$ catalisada por $\mathrm{SnO}_{\mathrm{x}} \mathrm{RuO}_{\mathrm{x}}-\mathrm{Pt} / \mathrm{C}$ após EOR a $25^{\circ} \mathrm{C}$. Velocidade de varredura de $0,01 \mathrm{~V} \mathrm{~s}^{-1}$.

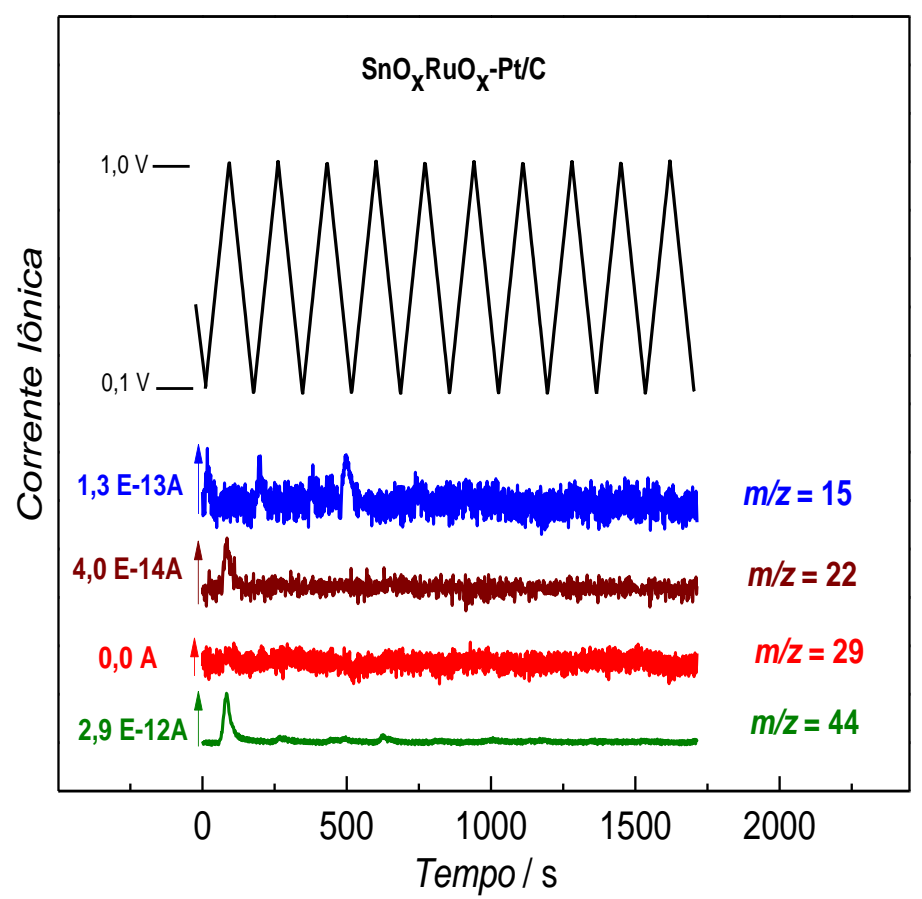

Fonte: Autoria própria

Figura 24- (a) Perfis voltamétricos e (b) correntes iônicas obtidas em experimentos de DEMS durante a EOR catalisada por $\mathrm{SnO}_{\mathrm{x}} \mathrm{RuO}_{\mathrm{x}}-\mathrm{Pt} / \mathrm{C}$ em $0,1 \mathrm{~mol} \mathrm{~L}^{-1}$ etanol $+2 \mathrm{~mol} \mathrm{~L}^{-1} \mathrm{H}_{2} \mathrm{SO}_{4}$ a $25^{\circ} \mathrm{C}$. Velocidade de varredura de $0,01 \mathrm{~V} \mathrm{~s}^{-1}$.

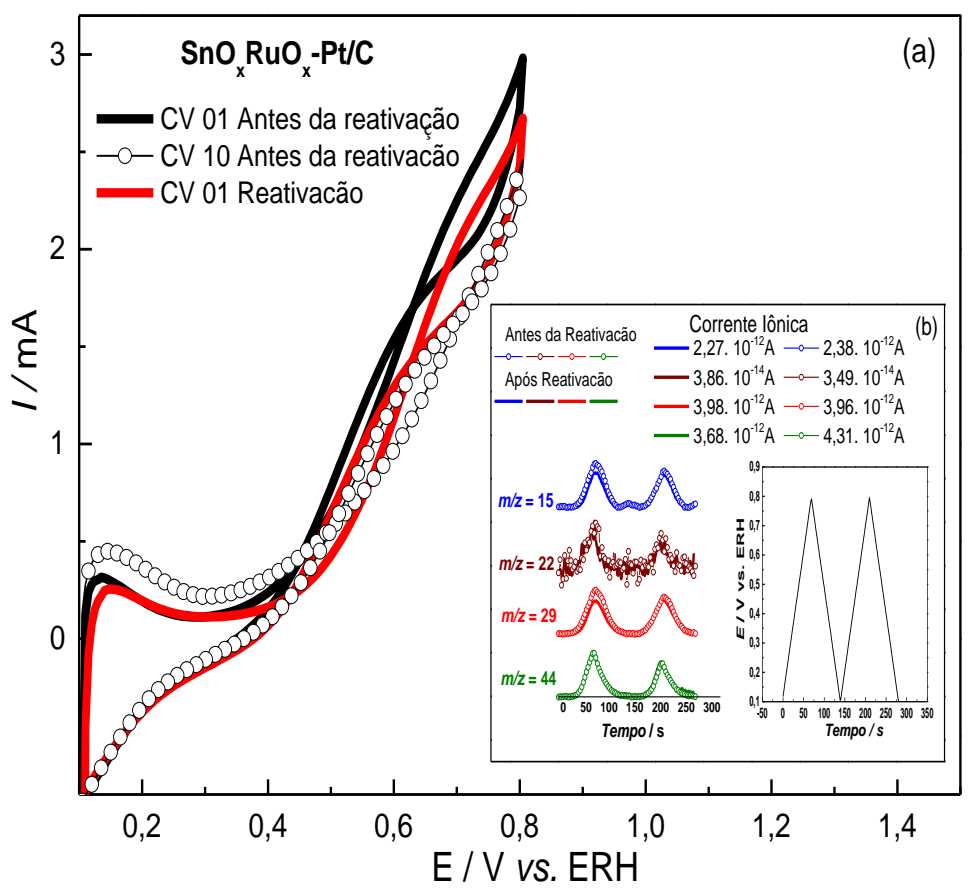

Fonte: Autoria própria 
2.4.4 Experimentos de DEMS para a Eletro-oxidação de Etanol em Temperatura Intermediária Usando Ácido Sólido como Eletrólito.

Com o objetivo de aumentar a ativação e a taxa global de quebra de ligações na molécula de etanol e em intermediários reacionais adsorvidos, evitando o envenenamento da superfície eletrocatalítica (como mostrado na seção anterior), o estudo da reação de eletro-oxidação de etanol foi feito em temperatura intermediária $\left(245^{\circ} \mathrm{C}\right)$. Para este estudo, os experimentos foram realizados utilizando-se como eletrólito um ácido sólido superprotônico, $\mathrm{CsH}_{2} \mathrm{PO}_{4}$, sendo a análise dos produtos reacionais feita através de medidas on-line utilizando espectrometria de massas.

A Figura 25 apresenta os perfis voltamétricos, em meia-célula (utilizando um eletrodo dinâmico de hidrogênio como eletrodo de referência), para a reação de eletrooxidação de etanol eletrocatalisada por $\mathrm{SnO}_{\mathrm{x}} \mathrm{RuO}_{\mathrm{x}}-\mathrm{Pt} / \mathrm{C}$ e $\mathrm{Pt} / \mathrm{C} 50 \%$ (Figura 25(a)) e $\mathrm{SnO}_{\mathrm{x}} \mathrm{RuO}_{\mathrm{x}}-\mathrm{Pt} / \mathrm{C}$ e Pt black (Figura 25(b)) em etanol 36\% (linha + símbolo) e somente em eletrólito (linha contínua) a $245^{\circ} \mathrm{C}$. Como pode ser observado, há um aumento significativo na corrente faradaica quando a solução de etanol $36 \%$ é bombeada para a célula, para todos os materiais. Por outro lado, a tendência observada na intensidade das correntes e nos perfis voltamétricos não é a mesma daquelas obtidas em temperatura ambiente (ver Figura 18). Considerando a grande diferença entre $25^{\circ} \mathrm{C}$ e $245^{\circ} \mathrm{C}$, é esperado uma significativa variação no mecanismo envolvido na reação de eletrooxidação do etanol. No entanto, é possível observar que as correntes obtidas para o material ternário são ligeiramente maiores em relação às correntes para platina black (Figura 25 (b)) em maiores valores de potenciais e o oposto é observado quando se tem Pt/C 50\% (Figura 25(a)). Comparando ambos os perfis para platina, conclui-se que o desempenho catalítico do material é independente da natureza do catalisador, mas depende da área superficial do mesmo (Pt/C 50\% 60 $\mathrm{m}^{2} \mathrm{~g}^{-1}$ e Pt black $25 \mathrm{~m}^{2} \mathrm{~g}^{-1}$ ). As medidas 
cronoamperométricas Figura 26(a) foram realizadas a partir de saltos de potenciais entre os potenciais de circuito aberto $(\sim 0,3 \mathrm{~V})$ e 0,5 e $0,8 \mathrm{~V}$, na presença e na ausência de etanol, conforme detalhado na figura 26. Nesta figura também são apresentadas as correntes iônicas para a formação de $\mathrm{CO}_{2}(m / z=22)\left(\right.$ b) e de $\mathrm{H}_{2}(m / z=2)$ (c), obtidas utilizando espectrometria de massas on-line, com sensor de ponta de Teflon poroso (ver Figura 12(c)). Os resultados mostram a formação de $\mathrm{H}_{2}$ e de $\mathrm{CO}_{2}$, na presença de etanol, em circuito aberto ( $\sim, 3 \mathrm{~V})$. Isso indica que, em $245^{\circ} \mathrm{C}$, ocorrem reações puramente químicas, com catálise heterogênea, de decomposição do etanol. Quando o potencial é avançado para $0,5 \mathrm{~V}$ e, em seguida, para $0,8 \mathrm{~V}$, têm-se o aparecimento de corrente faradaica e o aumento das correntes iônicas de formação de $\mathrm{CO}_{2}$ e uma diminuição da magnitude das correntes para $\mathrm{H}_{2}$, indicando a ocorrência da oxidação eletroquímica do etanol e, paralelamente, a oxidação eletroquímica do hidrogênio (consumo), produzido nos passos puramente químicos. 
Figura 25 - Perfis voltamétricos durante medidas de eletro-oxidação de etanol catalisada por (a) $\mathrm{SnO}_{x} \mathrm{RuO}_{\mathrm{x}}-\mathrm{Pt} / \mathrm{C}$ e Pt/C 50\% e (b) $\mathrm{SnO}_{x} \mathrm{RuO}_{\mathrm{x}}-\mathrm{Pt} / \mathrm{C}$ e Pt black em etanol $36 \%$ (linha + símbolo) e somente em eletrólito, $\mathrm{CsH}_{2} \mathrm{PO}_{4}$ (linha) a $245^{\circ} \mathrm{C}$. Velocidade de varredura $0,01 \mathrm{~V} \mathrm{~s}^{-1}$. (Sem correção por queda ôhmica).
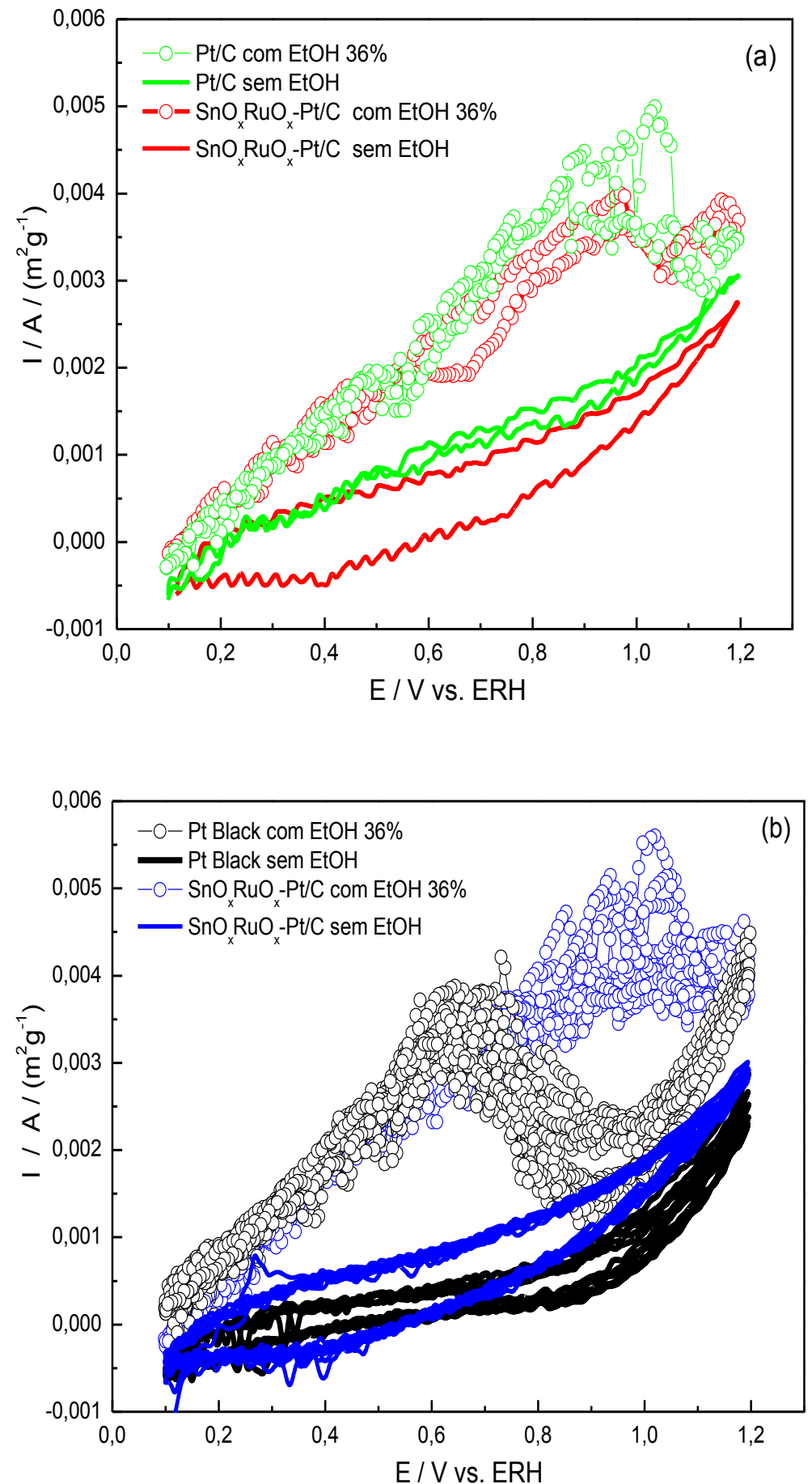

Fonte: Autoria própria 
Os valores determinados para as eficiências de corrente para a eletro conversão para $\mathrm{CO}_{2}$ a $0,5 \mathrm{~V}$ e $0,8 \mathrm{~V}$, (rota eletroquímica), estão apresentados na Tabela 5. Observase que as correntes faradaicas para a conversão para $\mathrm{CO}_{2}$ para $\mathrm{Pt} / \mathrm{C}$ foram de $45 \%$ em 0,5 e em $0,8 \mathrm{~V}$ e, para $\mathrm{SnO}_{\mathrm{x}} \mathrm{RuO}_{\mathrm{x}}-\mathrm{Pt} / \mathrm{C}$, foram de $36 \%$ e $50 \%$ em 0,5 e $0,8 \mathrm{~V}$, respectivamente. Portanto, na média, estes valores são significativamente mais altos do que os valores obtidos em temperatura ambiente. Nota-se que, em $0,5 \mathrm{~V}, \mathrm{Pt} / \mathrm{C}$ possui maior eficiência de conversão e, em $0,8 \mathrm{~V}$, os valores para ambos os eletrocatalisadores são muito próximos. Possivelmente, em $245^{\circ} \mathrm{C}$, a ativação de moléculas de água, com a formação de espécies $\mathrm{OH}$ na superfície da platina, em Pt/C, ocorre em menores valores de potenciais, quando comparado com a ativação em temperatura ambiente. Ademais, é provável que, em baixos potenciais, o número de sítios ativos responsáveis pela quebra da ligação C-C (que é mais ativada em $245^{\circ} \mathrm{C}$ ) seja maior na superfície de $\mathrm{Pt} / \mathrm{C}$ em relação ao material de $\mathrm{SnO}_{\mathrm{x}} \mathrm{RuO}_{\mathrm{x}}-\mathrm{Pt} / \mathrm{C}$. Assim, o uso de metais oxofilicos, como $\mathrm{Sn}$ e $\mathrm{Ru}$, nesta condição experimental, torna-se menos importante do que em temperatura ambiente.

De acordo com os resultados obtidos, a $245^{\circ} \mathrm{C}$, a reação de oxidação de etanol ocorre por duas vias paralelas e simultâneas: uma rota química, com catálise heterogênea, (thermal reactions), e uma segunda rota puramente eletroquímica. Nesta condição, os produtos detectados foram apenas $\mathrm{CO}_{2}(\mathrm{~m} / \mathrm{z}=22$ e 44$)$ e hidrogênio $(\mathrm{m} / \mathrm{z}=2)$, sendo o principal fragmento para acetaldeido $(\mathrm{m} / \mathrm{z}=29)$ não detectado. 
Figura 26 - (a) Curvas cronoamperométricas para a eletro-oxidação de etanol em $\mathrm{SnO}_{\mathrm{x}} \mathrm{RuO}_{\mathrm{x}}-\mathrm{Pt} / \mathrm{C}$ e $\mathrm{Pt} / \mathrm{C}$ em etanol $36 \%$ a $245^{\circ} \mathrm{C}$, com monitoramento dos sinais de massa (b) $m / z=22\left(\mathrm{CO}_{2}\right)$ e (c) $m / z=2\left(\mathrm{H}_{2}\right)$. As curvas foram realizadas através de saltos potenciostáticos entre os potenciais de circuito aberto e 0,5V e 0,8 V vs. DHE (Dynamic Hydrogen Electrode), na presença e na ausência de etanol, fluxo de alimentação $7,2 \mathrm{~mL} \mathrm{~h}^{-1}$.

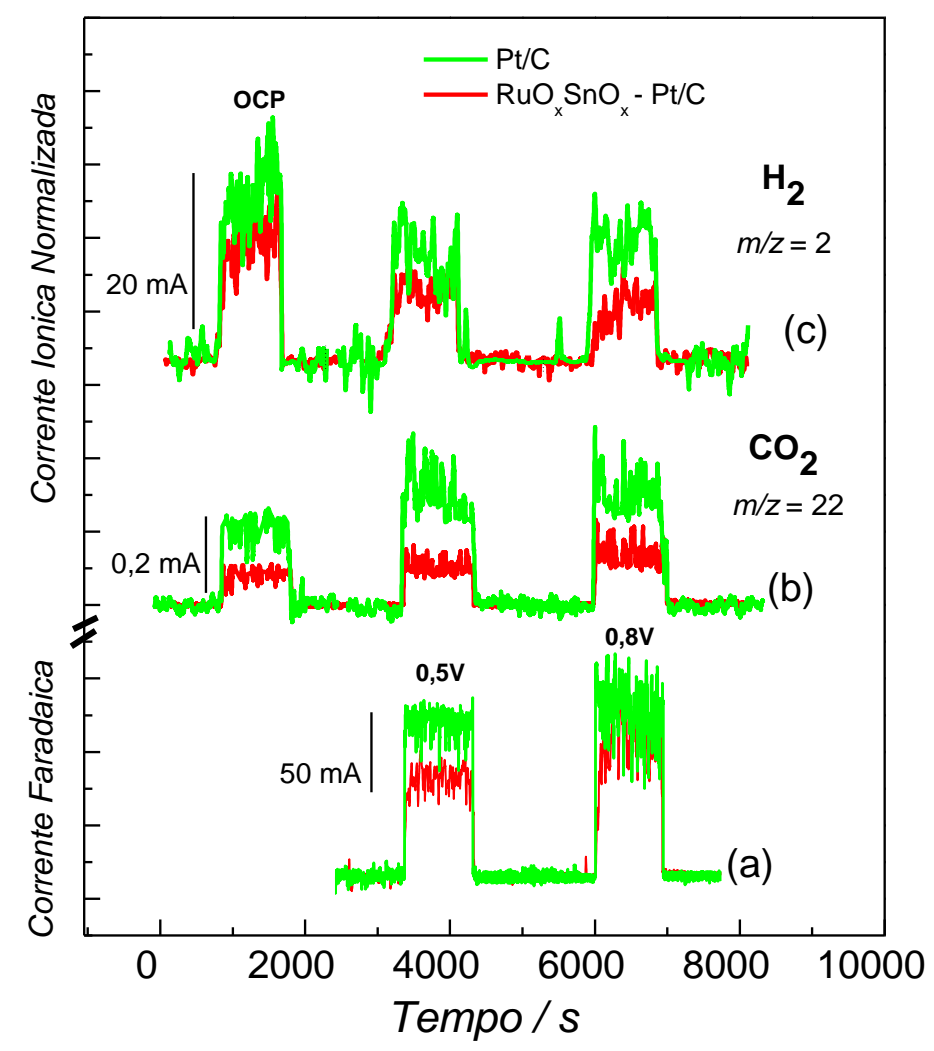

Fonte: Autoria própria.

Tabela 5 - Eficiências médias de corrente $(\mathrm{Aq})$ para $\mathrm{CO}_{2}$, durante a eletro-oxidação de etanol catalisada por $\mathrm{SnO}_{\mathrm{x}} \mathrm{RuO}_{\mathrm{x}}-\mathrm{Pt} / \mathrm{C}$ e Pt/C 50\% Alfa Aesar obtidas em 36\% de etanol a $245^{\circ} \mathrm{C}$.

\begin{tabular}{cccc}
\hline Eletrocatalisadores & $\mathbf{K}_{2}{ }^{*}$ & \multicolumn{2}{c}{ Eficiência de conversão para } \\
$\mathbf{C O}_{\mathbf{2}}$
\end{tabular}

Fonte: Autoria própria. 
Um trabalho prévio publicado por Shimada e colaboradores [90], mostrou que em temperatura intermediária a reação de oxidação de etanol sobre $\mathrm{Pt} / \mathrm{C}$ produz menos do que $5 \%$ de produtos contendo dois átomos de carbono na estrutura, como por exemplo acetaldeído e ácido acético, o que foi associado à maior temperatura de operação experimental empregada, que reduz a energia de ativação necessária para a clivagem da ligação C-C. De acordo com este trabalho, as principais reações que acontecem sobre Pt/C nesta condição são: (i) reações químicas: desidrogenação de etanol, decomposição do acetaldeído e deslocamento gás d'água e (ii) reações eletroquímicas: eletro-oxidação de etanol e hidrogênio, conforme ilustrado na Figura 27.

Figura 27- Esquema para as principais rotas reacionais seguidas pela reação de etanol (rotas químicas e eletroquímicas) em temperatura intermediária $\left(245^{\circ} \mathrm{C}\right)$.

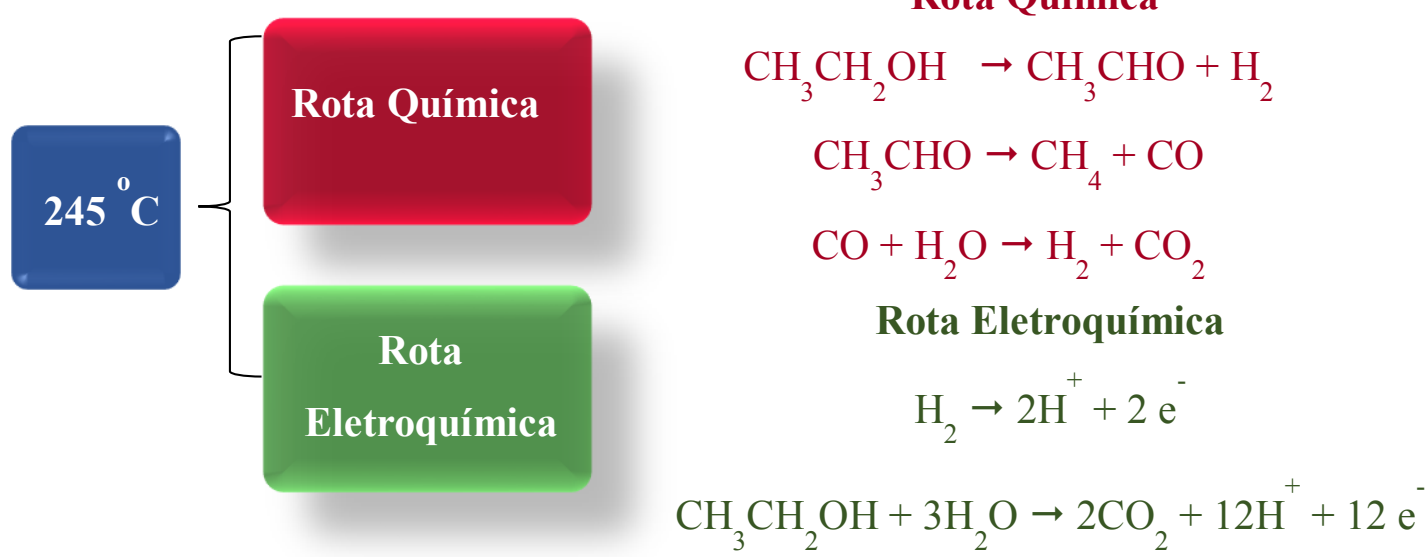




\section{CONCLUSÕES}

Os resultados obtidos na primeira parte deste trabalho mostraram que $\mathrm{Ru} / \mathrm{Pt} / \mathrm{C} \mathrm{e}$ $\mathrm{Sn} / \mathrm{Pt} / \mathrm{C}$ apresentaram maiores taxas reacionais global quando comparado à $\mathrm{Pt} / \mathrm{C}$ em baixos sobrepotenciais, mas não foram seletivos para as rotas $\mathrm{C}_{1} \mathrm{e} \mathrm{C}_{2}$, catalisando a reação produzindo $\mathrm{CO}_{2}$ e acetaldeído em vias paralelas. $\mathrm{Ru} / \mathrm{Pt} / \mathrm{C}$ apresentou a mais alta eficiência de corrente para formação de $\mathrm{CO}_{2}(16,6 \%)$. O aumento do teor $\mathrm{Sn}$ não alterou significativamente a proporção entre $\mathrm{CO}_{2}$ e acetaldeído. Por outro lado, W/Pt/C, com maior conteúdo de W (2:3) foi seletivo para o caminho $\mathrm{C}_{2}$. Adicionalmente, W/Pt/C (2:3) foi praticamente inativo para a eletro-oxidação de acetaldeído e ativo e mais estável para a eletro-oxidação de $\mathrm{H}_{2}$ na ausência e na presença de acetaldeído, contrariamente ao observado para Pt/C pura. Isto foi atribuído a habilidade de W/Pt/C para oxidar $\mathrm{H}_{2}$ e sua incapacidade para quebrar a ligação C-C, que inibiu a formação de espécies adsorvidas envenenadoras $\mathrm{CO}$ e $\mathrm{CH}_{\mathrm{x}}$. Em um ponto de vista prático o material W/Pt/C, com maior quantidade de $\mathrm{W}$, poderia ser usado como eletrocatalisador no ânodo de células a combustível de hidrogênio indireto, visto que este material é ativo para a oxidação de $\mathrm{H}_{2}$ e tolerante à presença de subprodutos tais como acetaldeído e etanol não reagido.

A parte 2 deste trabalho mostrou que $\mathrm{SnO}_{\mathrm{x}} \mathrm{RuO}_{\mathrm{x}}-\mathrm{Pt} / \mathrm{C}$ e $\mathrm{Pt} / \mathrm{C}$ possuem eficiências médias de conversão para formação de $\mathrm{CO}_{2}$ próximas ( 16\%), em temperatura ambiente, mas com menor potencial de onset e maiores densidades de corrente para $\mathrm{o}$ eletrocatalisador trimetálico, o que foi explicado pela presença dos óxidos oxofilicos de Sn e $\mathrm{Ru}$. O caminho reacional $\mathrm{C}_{2}$ prevaleceu nesta temperatura, sendo o acetaldeído o produto majoritário. Experimentos de DEMS on-line com célula de fluxo mostraram um decréscimo da corrente faradaica para a eletro-oxidação de etanol em função do tempo, o que foi associado à formação de espécies intermediárias com um átomo de carbono, que se adsorvem fortemente sobre a superfície catalítica, bloqueando os sítios ativos 
necessários para a adsorção de etanol. Estes resultados indicam que em temperatura ambiente, a platina sofre envenenamento mesmo com a presença de metais oxofílicos. Por outro lado, os resultados obtidos a $245^{\circ} \mathrm{C}$ mostraram que a EOR ocorre por duas vias paralelas e simultâneas com formação de $\mathrm{CO}_{2}$ e de $\mathrm{H}_{2}$ como produtos majoritários: (i) uma rota química, com catálise heterogênea; (ii) uma rota puramente eletroquímica. Neste segundo caso, os produtos detectados foram apenas $\mathrm{CO}_{2}(\mathrm{~m} / \mathrm{z}=22$ e 44$)$, que aumenta com o potencial, e o hidrogênio $(\mathrm{m} / \mathrm{z}=2)$, que é consumido com o aumento do potencial, devido à sua oxidação eletroquímica, também contribuindo para a corrente faradaica. Vale mencionar que o principal fragmento para acetaldeido $(\mathrm{m} / z=29)$ não foi detectado nestas condições. Para $\mathrm{SnO}_{x} \mathrm{RuO}_{\mathrm{x}}-\mathrm{Pt} / \mathrm{C}$, a eficiência faradaica de conversão para $\mathrm{CO}_{2}$ foi de $36 \%$ em $0,5 \mathrm{~V}$ e $50 \%$ em $0,8 \mathrm{~V}$ e, para $\mathrm{Pt} / \mathrm{C}$, os resultados mostraram eficiências próximas de $45 \%$ nos dois potenciais. Portanto, no geral, os resultados de espectrometria de massas mostram um significativo efeito da temperatura na eficiência de eletro conversão de etanol a $\mathrm{CO}_{2}$, mas pouco ou nenhum efeito da natureza do eletrocatalisador. Possivelmente, maior ativação da quebra de moléculas de água e da quebra da ligação CC na superfície da platina, resultante do aumento da temperatura para $245^{\circ} \mathrm{C}$, torna pouco observável o efeito benéfico da adição de um metal oxifílico à platina, como visto em temperatura ambiente. 


\section{REFERÊNCIAS}

[1] EBERLE, D.U.; VON HELMOLT, D.R. Sustainable transportation based on electric vehicle concepts: a brief overview. Energy \& Environmental Science, v. 3, n. 6, p. 689-699, 2010.

[2] EBERLE, U.; FELDERHOFF, M.; SCHUTH, F. Chemical and physical solutions for hydrogen storage. Angewandte Chemie - International Edition, v. 48, n. 36, p. 6608-6630, 2009.

[3] CROTOGINO, F.; DONADEI, S. Large-scale hydrogen underground storage for securing future energy supplies. In: 18th World Hydrogen Energy Conference, 78, 2010, Forschungszentrun Jilich. Proceeding. Germany, 2010. p. 37-45.

[4] AKDIM, O.; DEMIRCI, U. B.; MIELE, P. Deactivation and reactivation of cobalt in hydrolysis of sodium borohydride. International Journal of Hydrogen Energy, v. 36, n. 21, p. 13669-13675, 2011.

[5] OZEROVA, A. M.; BULAVCHENKO, O. A.; KOMOVA, O. V.; NETSKINA, O. V.; ZAIKOVSKII, V. I.; ODEGOVA, G. V.; SIMAGINA, V. I. Cobalt boride catalysts for hydrogen storage systems based on $\mathrm{NH}_{3} \mathrm{BH}_{3}$ and $\mathrm{NaBH}_{4}$. Kinetics and Catalysis, v. 53, n. 4, p. 511-520, 2012.

[6] GREEN, S. K.; TOMPSETT, G. A.; KIM, H. J.; BAE KIM, W.; HUBER, G. W. Electrocatalytic reduction of acetone in a proton-exchange-membrane reactor: a model reaction for the electrocatalytic reduction of biomass. ChemSusChem, v. 5, n. 12, p. 2410-20, 2012.

[7] LAMY, C.; DEVADAS, A.; SIMOES, M.; COUTANCEAU, C. Clean hydrogen generation through the electrocatalytic oxidation of formic acid in a Proton Exchange Membrane Electrolysis Cell (PEMEC). Electrochimica Acta, v. 60, p. 112-120, 2012.

[8] ARAUJO, C. M.; SIMONE, D. L.; KONEZNY, S. J.; SHIM, A.; CRABTREE, R. H.; SOLOVEICHIK, G. L.; BATISTA, V. S. Fuel selection for a regenerative organic fuel cell/flow battery: thermodynamic considerations. Energy \& Environmental Science, v. 5, n. 11, p. 9534-9542, 2012. 
[9] DRISCOLL, P.; DEUNF, E.; RUBIN, L.; LUCA, O.; CRABTREE, R.; CHIDSEY, C.; ARNOLD, J.; KERR, J. Redox catalysis for dehydrogenation of liquid hydrogen carrier fuels for energy storage and conversion. ECS Transactions, v. 35, p. 3-17, 2011.

[10] KARIYA, N.; FUKUOKA, A.; ICHIKAWA, M. Direct PEM fuel cell using "organic chemical hydrides" with zero- $\mathrm{CO}_{2}$ emission and low-crossover. Physical Chemistry Chemical Physics, v. 8, n. 14, p. 1724-30, 2006.

[11] VIELSTICH, W.; LAMM, A.; GASTEIGER, H. A. Handbook of fuel cells: fundamentals, technology and applications, Chichester: Wiley, 2003, v. 3, p. 190.

[12] LIMA, S. M.; COLMAN, R. C.; JACOBS, G.; DAVIS, B. H.; SOUZA, K. R.; LIMA, A. F. F.; APPEL, L. G.; MATTOS, L. V.; NORONHA, F. B. Hydrogen production from ethanol for PEM fuel cells. An integrated fuel processor comprising ethanol steam reforming and preferential oxidation of CO. Catalysis Today, v. 146, n. 1-2, p. 110-123, 2009.

[13] NERAMITTAGAPONG, A.; ATTAPHAIBOON, W.; NERAMITTAGAPONG, S. Acetaldehyde production from ethanol over Ni-based catalysts. Chiang Mai Journal of Science, v. 35, n. 1, p. 171-177, 2008.

[14] SATO, A. G.; VOLANTI, D. P.; MEIRA, D. M.; DAMYANOVA, S.; LONGO, E.; BUENO, J. M. C. Effect of the $\mathrm{ZrO}_{2}$ phase on the structure and behavior of supported $\mathrm{Cu}$ catalysts for ethanol conversion. Journal of Catalysis, v. 307, p. 1-17, 2013.

[15] SATO, A. G.; VOLANTI, D. P.; FREITAS, I. C.; LONGO, E.; BUENO, J. M. C. Site-selective ethanol conversion over supported copper catalysts. Catalysis

Communications, v. 26, p. 122-126, 2012.

[16] ZIGNANI, S. C.; BAGLIO, V.; LINARES, J. J.; MONFORTE, G.; GONZALEZ, E. R.; ARICO, A. S. Endurance study of a solid polymer electrolyte direct ethanol fuel cell based on a Pt-Sn anode catalyst. International Journal of Hydrogen Energy, v. 38, n. 26, p. 11576-11582, 2013.

[17] ALMEIDA, T. S.; PALMA, L. M.; MORAIS, C.; KOKOH, K. B.; ANDRADE, A. R. Effect of adding a third metal to carbon-supported PtSn-based nanocatalysts for direct ethanol fuel cell in acidic medium. Journal of the Electrochemical Society, $v$. 160, n. 9, p. F965-F971, 2013. 
[18] ANDREADIS, G.; STERGIOPOULOS, V.; SONG, S.; TSIAKARAS, P. Direct ethanol fuel cells: the effect of the cell discharge current on the products distribution. Applied Catalysis B: Environmental, v. 100, n. 1-2, p. 157-164, 2010.

[19] KARIYA, N.; FUKUOKA, A.; ICHIKAWA, M. Zero-CO $\mathrm{CO}_{2}$ emission and lowcrossover "rechargeable" PEM fuel cells using cyclohexane as an organic hydrogen reservoir. Chemical Communications, n. 6, p. 690-691, 2003.

[20] IWASITA, T.; PASTOR, E. A dems and FTir spectroscopic investigation of adsorbed ethanol on polycrystalline platinum. Electrochimica Acta, v. 39, n. 4, p. 531537, 1994.

[21] LAMY, C.; LIMA, A.; LERHUN, V.; DELIME, F.; COUTANCEAU, C.; LÉGER, J.-M. Recent advances in the development of direct alcohol fuel cells (DAFC). Journal of Power Sources, v. 105, n. 2, p. 283-296, 2002.

[22] SOUZA, J. P. I.; QUEIROZ, S. L.; BERGAMASKI, K.; GONZALEZ, E. R.; NART, F. C. Electro-oxidation of ethanol on Pt, Rh, and PtRh electrodes. A study using DEMS and in-Situ FTIR techniques. The Journal of Physical Chemistry B, v. 106, n. 38, p. 9825-9830, 2002.

[23] COLLE, V. Del; SOUZA-GARCIA, J.; TREMILIOSI-FILHO, G.; HERRERO, E.; FELIU, J. M. Electrochemical and spectroscopic studies of ethanol oxidation on Pt stepped surfaces modified by tin adatoms. Physical Chemistry Chemical Physics, v. 13, n. 26, p. 12163-72, 2011.

[24] WANG, H.; JUSYS, Z.; BEHM, R. J. Ethanol electro-oxidation on carbonsupported $\mathrm{Pt}$, PtRu and $\mathrm{Pt}_{3} \mathrm{Sn}$ catalysts: a quantitative DEMS study. Journal of Power Sources, v. 154, n. 2, p. 351-359, 2006.

[25] CANTANE, D. A.; AMBROSIO, W. F.; CHATENET, M.; LIMA, F. H. B. Electro-oxidation of ethanol on $\mathrm{Pt} / \mathrm{C}, \mathrm{Rh} / \mathrm{C}$, and $\mathrm{Pt} / \mathrm{Rh} / \mathrm{C}$-based electrocatalysts investigated by on-line DEMS. Journal of Electroanalytical Chemistry, v. 681, p. 56$65,2012$.

[26] WANG, H. F.; LIU, Z. P. Comprehensive mechanism and structure-sensitivity of ethanol oxidation on platinum: new transition-state searching method for resolving the complex reaction network. Journal of the American Chemical Society, v. 130, n. 33, p. 10996-1004, 2008. 
[27] SOUZA-GARCIA, J.; HERRERO, E.; FELIU, J. M. Breaking the C-C bond in the ethanol oxidation reaction on platinum electrodes: effect of steps and ruthenium adatoms. Chemphyschem : a European Journal of Chemical Physics and Physical Chemistry, v. 11, n. 7, p. 1391-4, 2010.

[28] COLMATI, F.; TREMILIOSI-FILHO, G.; GONZALEZ, E. R.; BERNÁ, A.; HERRERO, E.; FELIU, J. M. Surface structure effects on the electrochemical oxidation of ethanol on platinum single crystal electrodes. Faraday Discussion, v. 140, p. 379-397, 2009.

[29] LIMA, F. H. B.; PROFETI, D.; LIZCANO-VALBUENA, W. H.; TICIANELLI, E. A.; GONZALEZ, E. R. Carbon-dispersed Pt-Rh nanoparticles for ethanol electrooxidation. Effect of the crystallite size and of temperature. Journal of Electroanalytical Chemistry, v. 617, n. 2, p. 121-129, 2008.

[30] LAI, S. C. S.; KLEIJN, S. E. F.; ÖZTÜRK, F. T. Z.; VAN REES VELLINGA, V. C.; KONING, J.; RODRIGUEZ, P.; KOPER, M. T. M. Effects of electrolyte pH and composition on the ethanol electro-oxidation reaction. Catalysis Today, v. 154, n. 1-2, p. 92-104, 2010.

[31] ZHOU, W. P.; AXNANDA, S.; WHITE, M. G.; ADZIC, R. R.; HRBEK, J. Enhancement in ethanol electrooxidation by $\mathrm{SnOx}$ nanoislands grown on $\mathrm{Pt}(111)$ : effect of metal oxide-metal interface sites. The Journal of Physical Chemistry C, v. 115, n. 33, p. 16467-16473, 2011.

[32] ANTOLINI, E. Catalysts for direct ethanol fuel cells. Journal of Power Sources, v. 170, n. 1, p. 1-12, 2007.

[33] KOWAL, A.; LI, M.; SHAO, M.; SASAKI, K.; VUKMIROVIC, M. B.; ZHANG, J.; MARINKOVIC, N. S.; LIU, P.; FRENKEL, A. I.; ADZIC, R. R. Ternary $\mathrm{Pt} / \mathrm{Rh} / \mathrm{SnO}_{2}$ electrocatalysts for oxidizing ethanol to $\mathrm{CO}_{2}$. Nature materials, v. 8 , n. 4 , p. 325-30, 2009.

[34] ANJOS, D. M.; HAHN, F.; LÉGER, J. M.; KOKOH, K. B.; TREMILIOSI-FILHO, G. Ethanol electrooxidation on Pt-Sn and Pt-Sn-W bulk alloys. Journal of the Brazilian Chemical Society, v. 19, n. 4, p. 795-802, 2008.

[35] XY, H.; CG, H.; QN, Y.; X, W.; H, H.; XY, L. Enhanced electrochemical activity of $\mathrm{Pt}$ supported on three-dimensional $\mathrm{WO}_{3}$ center dot $0.33 \mathrm{H}(2) \mathrm{O}$ networks for methanol and ethanol oxidation. Journal of the Electrochemical Society, v. 160, n. 6, p. F566F572, 2013. 
[36] RCH, M.; OU, R.; JG, F.; HC, L.; PR, T. A voltammetry study of ethanol oxidation on carbon supported, non alloyed platinum-tungsten catalysts. Journal of the

Electrochemical Society, v. 160, n. 3, p. H185-H191, 2013.

[37] MIECZNIKOWSKI, K. Enhancement of activity of PtRh nanoparticles towards oxidation of ethanol through modification with molybdenum oxide or tungsten oxide.

Journal of Solid State Electrochemistry, v. 16, n. 8, p. 2723-2731, 2012.

[38] ZHOU, W. Pt based anode catalysts for direct ethanol fuel cells. Applied Catalysis B: Environmental, v. 46, n. 2, p. 273-285, 2003.

[39] SATO, A. G.; SILVA, G. C. PAGANIN, V. A.; TICIANELLI, E. A. Hydrogen production on an ethanol dehydrogenation reactor coupled to a conventional PEMFC. ECS Transactions, v. 64, n. 3, p. 999-1005, 2014.

[40] SONG, S. Q.; ZHOU, W. J.; ZHOU Z. H.; JIANG, L. H.; SUN, G. Q.; XIN, Q.; LEONTIDIS, V.; KONTOU, S.; TSIAKARAS, P. Direct ethanol PEM fuel cells: the case of platinum based anodes. International Journal of Hydrogen Energy, v. 30, n. 9, p. 995-1001, 2005.

[41] ROUSSEAU, S.; COUTANCEAU, C.; LAMY, C.; LÉGER, J.-M. Direct ethanol fuel cell (DEFC): electrical performances and reaction products distribution under operating conditions with different platinum-based anodes. Journal of Power Sources, v. 158, n. 1 , p. $18-24,2006$.

[42] VIGIER, F.; COUTANCEAU, C.; PERRARD, A.; BELGSIR, E. M.; LAMY, C. Development of anode catalysts for a direct ethanol fuel cell. Journal of Applied Electrochemistry, v. 34, n. 4, p. 439-446, 2004.

[43] WU, G.; SWAIDAN, R.; CUI, G. Electrooxidations of ethanol, acetaldehyde and acetic acid using PtRuSn/C catalysts prepared by modified alcohol-reduction process. Journal of Power Sources, v. 172, n. 1, p. 180-188, 2007.

[44] ANTOLINI, E. Platinum-based ternary catalysts for low temperature fuel cells. Applied Catalysis B: Environmental, v. 74, n. 3-4, p. 337-350, 2007.

[45] WEST, A.R. Solid State Chemistry. New York: Wiley, 1984. 205p. 
[46] MASCARENHAS Y.P.; PINHEIRO J.M.V. Programa para cálculo de parâmetro de rede pelo método de mínimos quadrados. São Carlos: SBPC, 1985. 1CD-ROM.

[47] SCHMIDT, T. J.; GASTEIGER, H. A. Characterization of high-surface-area electrocatalysts using a rotating disk electrode configuration. Journal of the Electrochemical Society, v. 145, n. 7, p. 2354-2358, 1998.

[48] SOUZA, J. P. I.; QUEIROZ, S. L.; NART, F. C. The use of mass spectrometry in electrochemical measurements - The DEMS technique. Quimica Nova, v. 23, n. 3, p. 384-391, 2000.

[49] BITTINS-CATTANEO, B.; CATTANEO, E.; KÖNIGSHOVEN, P.; VIELSTICH, W. Electroanalytical Chemistry: A Series of Advances. New York: Marcel Dekker, 1991. $181 \mathrm{p}$.

[50] IANNIELLO, R.; SCHMIDT, V. M. A simplified DEMS set up for electrocatalytic studies of porous PtRu alloys. Berichte der Bunsengesellschaft für physikalische Chemie, v. 99, n. 1, p. 83-86, 1995.

[51] JIANG, L.; COLMENARES, L.; JUSYS, Z.; SUN, G. Q.; BEHM, R. J. Ethanol electrooxidation on novel carbon supported $\mathrm{Pt} / \mathrm{SnO}_{\mathrm{x}} / \mathrm{C}$ catalysts with varied $\mathrm{Pt}: \mathrm{Sn}$ ratio. Electrochimica Acta, v. 53, n. 2, p. 377-389, 2007.

[52] RAO, V.; CREMERS, C.; STIMMING, U.; CAO, L.; SUN, S.; YAN, S.; SUN, G.; XIN, Q. Electro-oxidation of ethanol at gas diffusion electrodes a DEMS study. Journal of the Electrochemical Society, v. 154, n. 11, p. B1138, 2007.

[53] CREMERS, C., KINTZEL, B., BAYER, D.; TÜBKE, J. Influence of the pH value and the carbonate ion concentration of the electrolyte solution on the ethanol oxidation at polycrystalline platinum. ECS Transactions, v. 33, p. 1681-1692, 2010.

[54] IÚDICE DE SOUZA, J.P.; IWASITA, T.; NART, F. C.; VIELSTICH, W. Performance evaluation of porous electrocatalysts via normalization of the active surface. Journal of Applied Electrochemistry, v. 30, n. 1, p. 43-48, 2000.

[55] WATANABE, M.; MOTOO, S. Electrocatalysis by ad-atoms: Part III. Enhancement of the oxidation of carbon monoxide on platinum by ruthenium ad-atoms. Journal of Electroanalytical Chemistry, v. 60, p. 275-283, 1975. 
[56] LIMA, F. H. B.; GONZALEZ, E. R. Electrocatalysis of ethanol oxidation on Pt monolayers deposited on carbon-supported $\mathrm{Ru}$ and $\mathrm{Rh}$ nanoparticles. Applied Catalysis B: Environmental, v. 79, n. 4, p. 341-346, 2008.

[57] LIMA, F. H. B.; PROFETI, D.; CHATENET, M.; RIELLO, D.; TICIANELLI, E. A.; GONZALEZ, E. R. Electro-oxidation of ethanol on $\mathrm{Rh} / \mathrm{Pt}$ and $\mathrm{Ru} / \mathrm{Rh} / \mathrm{Pt}$ submonolayers deposited on $\mathrm{Au} / \mathrm{C}$ nanoparticles. Electrocatalysis, v. 1, n. 1, p. 72-82, 2010 .

[58] BLIGAARD, T.; NORSKOV, J.K. Ligand effects in heterogeneous catalysis and electrochemistry. Electrochimica Acta, v. 52, n. 18, p. 5512-5516, 2007.

[59] GREELEY, J.; ROSSMEISL, J.; HELLMAN, A.; NORSKOV, J. K. Theoretical trends in particle size effects for the oxygen reduction reaction. Zeitschrift für Physikalische Chemie, v. 221, p. 1209-1220, 2007.

[60] WANG, H.; JUSYS, Z.; BEHM, R. J. Ethanol electrooxidation on a carbonsupported Pt catalyst: reaction kinetics and product yields. The Journal of Physical Chemistry B, v. 108, n. 50, p. 19413-19424, 2004.

[61] ABD-EL-LATIf, A.A.; MOSTAFA, E.; HUXTER, S.; ATTARD, G.; BALTRUSCHAT, H. Electrooxidation of ethanol at polycrystalline and platinum stepped single crystals: a study by differential electrochemical mass spectrometry. Electrochimica Acta, v. 55, n. 27, p. 7951-7960, 2010.

[62] SUN, S.; HALSEID, M. C.; HEINEN, M.; JUSYS, Z.; BEHM, R. J. Ethanol electrooxidation on a carbon-supported Pt catalyst at elevated temperature and pressure: a high-temperature/high-pressure DEMS study. Journal of Power Sources, v. 190, n. 1, p. 2-13, 2009.

[63] JUSYS, Z.; KAISER, J.; BEHM, R. J. Methanol electrooxidation over Pt/C fuel cell catalysts: dependence of product yields on catalyst loading. Langmuir, v. 19, n. 17, p. 6759-6769, 2003.

[64] LIMA, F. H. B.; GONZALEZ, E. R. Ethanol electro-oxidation on carbonsupported Pt-Ru, Pt-Rh and Pt-Ru-Rh nanoparticles. Electrochimica Acta, v. 53, n. 6 , p. 2963-2971, 2008. 
[65] WANG, Y.; SONG, S.; ANDREADIS, G.; LIU, H.; TSIAKARAS, P.

Understanding the electrocatalytic activity of $\mathrm{Pt}_{\mathrm{x}} \mathrm{Sn}_{\mathrm{y}}$ in direct ethanol fuel cells. Journal of Power Sources, v. 196, n. 11, p. 4980-4986, 2011.

[66] SONG, S.; HE, C.; LIU, J.; WANG, Y.; BROUZGOU, A.; TSIAKARAS, P. Twostep sequence for synthesis of efficient PtSn@Rh/C catalyst for oxidizing ethanol and intermediate products. Applied Catalysis B: Environmental, v. 119-120, p. 227-233, 2012.

[67] NØRSKOV, J. K.; BLIGAARD, T.; LOGADOTTIR, A.; KITCHIN, J. R.; CHEN, J. G.; PANDELOV, S.; STIMMING, U. Trends in the exchange current for hydrogen evolution. Journal of The Electrochemical Society, v. 152, n. 3, p. J23-J26, 2005.

[68] PURGATO, F. L. S.; PRONIER, S.; OLIVI, P.; ANDRADE, A. R.; LEGER, J. M.; TREMILIOSI-FILHO, G.; KOKOH, K. B. Direct ethanol fuel cell: electrochemical performance at $90^{\circ} \mathrm{C}$ on $\mathrm{Pt}$ and $\mathrm{PtSn} / \mathrm{C}$ electrocatalysts. Journal of Power Sources, v. 198, p. 95-99, 2012.

[69] IWASITA, T. Electrocatalysis of methanol oxidation. Electrochimica Acta, v. 47, n. 22-23, p. 3663-3674, 2002.

[70] SHAO, M. H.; ADZIC, R. R. Electrooxidation of ethanol on a Pt electrode in acid solutions: in situ ATR-SEIRAS study. Electrochimica Acta, v. 50, n. 12, p. 24152422, 2005.

[71] HERRERO, E.; FRANASZCZUK, K.; WIECKOWSKI, A. Electrochemistry of methanol at low index crystal planes of platinum: an integrated voltammetric and chronoamperometric study. The Journal of Physical Chemistry, v. 98, n. 19, p. 50745083, 1994.

[72] VIELSTICH, W.; PAGANIN, V. A.; LIMA, F. H. B.; TICIANELLI, E. A. Nonelectrochemical pathway of methanol oxidation at a platinum-catalyzed oxygen gas diffusion electrode. ECS Transactions, v. 148, n. 5, p. A502, 2001.

[73] RADMILOVIC, V.; GASTEIGER, H. A.; ROSS, P. N. Structure and chemical composition of a supported Pt-Ru electrocatalyst for methanol oxidation. Journal of Catalysis, v. 154, n. 1, p. 98-106, 1995. 
[74] LIMA, F. H. B.; ZHANG, J.; SHAO, M. H.; SASAKI, K.; VUKMIROVIC, M. B.; TICIANELLI, E. A.; ADZIC, R. R. Catalytic activity-d-band center correlation for the $\mathrm{O}_{2}$ reduction reaction on platinum in alkaline solutions. Journal of Physical Chemistry C, v. 111, n. 1, p. 404-410, 2007.

[75] HAMMER, B.; NØRSKOV, J. K. Theoretical surface science and catalysis calculations and concepts. Advances in Catalysis, v. 45, p. 71-129, 2000.

[76] GREELEY, J.; NØRSKOV, J. K.; MAVRIKAKIS, M. Electronic structure and catalysis on metal surfaces. Annual review of physical chemistry, v. 53, p. 319-348, 2002.

[77] TREMILIOSI-FILHO, G.; KIM, H.; CHRZANOWSKI, W.; WIECKOWSKI, A.; GRZYBOWSKA, B.; KULESZA, P. Reactivity and activation parameters in methanol oxidation on platinum single crystal electrodes "decorated" by ruthenium adlayers.

Journal of Electroanalytical Chemistry, v. 467, n. 1, p. 143-156, 1999.

[78] COLLE, V. Del; SANTOS, V. P.; TREMILIOSI-FILHO, G. Comparative Electrochemical and Spectroscopic Studies of Ethanol Oxidation on $\mathrm{Pt}(\mathrm{h}, \mathrm{k}, \mathrm{l})$ Modified by Osmium Nanoislands. Electrocatalysis, v. 1, n. 2-3, p. 144-158, 2010.

[79] VIGIER, F., ROUSSEAU, S.; COUTANCEAU, C.; LEGER, J. M.; LAMY C. Electrocatalysis for the direct alcohol fuel cell. Topics in Catalysis. v. 40, p. 111-121, 2006.

[80] LI, M.; KOWAL, A.; SASAKI, K.; MARINKOVIC, N.; SU, D.; KORACH, E.; LIU, P.; ADZIC, R. R. Ethanol oxidation on the ternary Pt-Rh-SnO $/$ /C electrocatalysts with varied Pt:Rh:Sn ratios. Electrochimica Acta, v. 55, n. 14, p. 4331-4338, 2010.

[81] SCHMIEMANN, U.; MÜLLER, U.; BALTRUSCHAT, H. The influence of the surface structure on the adsorption of ethene, ethanol and cyclohexene as studied by DEMS. Electrochimica Acta, v. 40, n. 1, p. 99-107, 1995.

[82] WANG, H.; JUSYS, Z.; BEHM, R. J. Ethanol and acetaldehyde adsorption on a carbon-supported Pt catalyst: a comparative DEMS study. Fuel Cells, v. 4, n. 12, p. 113-125, 2004.

[83] TARNOWSKI, D.J.; KORZENIEWSKI, C. Effects of surface step density on the electrochemical oxidation of ethanol to acetic acid. Journal of Physical Chemistry B, v. 101, p. 253-258, 1997. 
[84] FUJIWARA, N.; FRIEDRICH, K.A.; STIMMING, U. Ethanol oxidation on PtRu electrodes studied by differential electrochemical mass spectrometry. Journal of Electroanalytical Chemistry, v. 472, n. 2, p. 120-125, 1999.

[85] CHISHOLM, R. I.; BOYSEN, D. A.; PAPANDREW, A. B.; ZECEVIC, S.; CHA, S.; SASAKI, K. A.; VARGA, A.,; GIAPIS, K. P.; HAILE, S.M. From laboratory lreakthrough to technological realization: the development path for solid acid fuel cell. The Electrochemical Society Interface, p. 53-59, 2009.

[86] TANINOUCHI, Y.; UDA, T.; AWAKURA,Y. Dehydration of $\mathrm{CsH}_{2} \mathrm{PO}_{4}$ at temperatures higher than $260^{\circ} \mathrm{C}$ and the ionic conductivity of liquid product. Solid State Ionics, v. 178, n. 31-32, p. 1648-1653, 2008.

[87] TANINOUCHI, Y.; UDA, T.; AWAKURA,Y.; IKEDA, A.; HAILE, S. M. Dehydration behavior of the superprotonic conductor $\mathrm{CsH}_{2} \mathrm{PO}_{4}$ at moderate temperatures: 230 to $260^{\circ}$ C. Journal of Materials Chemistry, v. 17, n. 30, p. 3182, 2007.

[88] UDA, T.; BOYSEN, D. A.; CHISHOLM, C. R. I.; HAILE, S. M. Alcohol fuel cells at optimal temperatures. Electrochemical and Solid-State Letters, v. 9, n. 6, p. A261, 2006.

[89] UDA, T.; HAILE, S.M.Thin-membrane solid-acid fuel cell. Electrochemical and Solid-State Letters, v. 8, n. 5, p. A245-A246, 2005.

[90] SHIMADA, I.; OSHIMA, Y.; OTOMO, J. Acceleration of ethanol electrooxidation on a carbon-supported platinum catalyst at intermediate temperatures. Journal of the Electrochemical Society, v. 158, n. 4, p. B369, 2011.

[91] BALTRUSCHAT, H. Differential electrochemical mass spectrometry. Journal of the American Society for Mass Spectrometry, v. 15, n. 12, p. 1693-1706, 2004. 